\title{
Nutritional Components in Western Diet Versus Mediterranean Diet at the Gut Microbiota-Immune System Interplay. Implications for Health and Disease
}

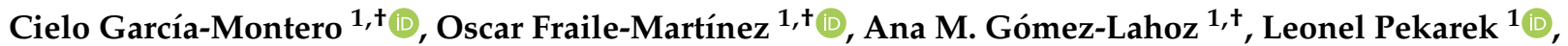 \\ Alejandro J. Castellanos ${ }^{1}$, Fernando Noguerales-Fraguas 2,3, Santiago Coca 1,4,5, Luis G. Guijarro 4,6, \\ Natalio García-Honduvilla 1,4,5, Angel Asúnsolo 2,4 ${ }^{\mathbb{D}}$, Lara Sanchez-Trujillo 1,4,7 (D), Guillermo Lahera 1,4,8 ${ }^{1}$, \\ Julia Bujan 1,4,5 D, Jorge Monserrat 1,4,5, ${ }^{(D)}$, Melchor Álvarez-Mon 1,4,5,9, $\ddagger$, Miguel A. Álvarez-Mon 1,4,5,10,*, \\ and Miguel A. Ortega $1,4,5,11, \ddagger$ (D)
}

1 Department of Medicine and Medical Specialities, Faculty of Medicine and Health Sciences, University of Alcalá, 28801 Alcalá de Henares, Spain; cielo.gmontero@gmail.com (C.G.-M.); oscarfra.7@hotmail.com (O.F.-M.); alahoz1199@gmail.com (A.M.G.-L.); leonel.pekarek@gmail.com (L.P.); alejandrolivealcala@gmail.com (A.J.C.); natalio.garcia@uah.es (N.G.-H.); mjulia.bujan@uah.es (J.B.); jorge.monserrat@uah.es (J.M.)

check for updates

Citation: García-Montero, C.; Fraile-Martínez, O.; Gómez-Lahoz, A.M.; Pekarek, L.; Castellanos, A.J.; Noguerales-Fraguas, F.; Coca, S.; Guijarro, L.G.; García-Honduvilla, N Asúnsolo, A.; et al. Nutritional Components in Western Diet Versus Mediterranean Diet at the Gut Microbiota-Immune System Interplay. Implications for Health and Disease. Nutrients 2021, 13, 699. https://doi.org/10.3390/nu13020699

Academic Editor:

Christoph Reinhardt

Received: 17 January 2021

Accepted: 18 February 2021

Published: 22 February 2021

Publisher's Note: MDPI stays neutral with regard to jurisdictional claims in published maps and institutional affiliations.

Copyright: (c) 2021 by the authors. Licensee MDPI, Basel, Switzerland. This article is an open access article distributed under the terms and conditions of the Creative Commons Attribution (CC BY) license (https:// creativecommons.org/licenses/by/ $4.0 /)$.
2 Department of Surgery, Medical and Social Sciences, Faculty of Medicine and Health Sciences, University of Alcalá, 28801 Alcala de Henares, Spain; fernando.noguerales@uah.es (F.N.-F.); angel.asunsolo@uah.es (A.A.)

3 Department of General Surgery, Príncipe de Asturias Hospital, 28806 Alcalá de Henares, Spain

4 Ramón y Cajal Institute of Sanitary Research (IRYCIS), 28034 Madrid, Spain; s.coca@uah.es (S.C.); larasancheztrujillo@gmail.com (L.S.-T.)

5 University Center for the Defense of Madrid (CUD-ACD), 28047 Madrid, Spain

6 Unit of Biochemistry and Molecular Biology (CIBEREHD), Department of System Biology, University of Alcalá, 28801 Alcalá de Henares, Spain; luis.gonzalez@uah.es

7 Service of Pediatric, Hospital Universitario Principe de Asturias, Alcalá de Henares,28806 Madrid, Spain

8 Psychiatry Service, Center for Biomedical Research in the Mental Health Network, University Hospital Príncipe de Asturias, 28806 Alcalá de Henares, Spain; guillermo.lahera@gmail.com

9 Immune System Diseases-Rheumatology, Oncology Service an Internal Medicine, University Hospital Príncipe de Asturias, (CIBEREHD), 28806 Alcalá de Henares, Spain; mademons@gmail.com

10 Department of Psychiatry and Medical Psychology, Hospital Universitario Infanta Leonor, 28031 Madrid, Spain

11 Cancer Registry and Pathology Department, Hospital Universitario Principe de Asturias, 28806 Alcalá de Henares, Spain; miguel.angel.ortega92@gmail.com

* Correspondence: maalvarez.gonzalez@salud.madrid.org

+ These authors contributed equality to this work.

$\ddagger$ These authors shared senior authorship in this work.

Abstract: The most prevalent diseases of our time, non-communicable diseases (NCDs) (including obesity, type 2 diabetes, cardiovascular diseases and some types of cancer) are rising worldwide. All of them share the condition of an "inflammatory disorder", with impaired immune functions frequently caused or accompanied by alterations in gut microbiota. These multifactorial maladies also have in common malnutrition related to physiopathology. In this context, diet is the greatest modulator of immune system-microbiota crosstalk, and much interest, and new challenges, are arising in the area of precision nutrition as a way towards treatment and prevention. It is a fact that the westernized diet (WD) is partly responsible for the increased prevalence of NCDs, negatively affecting both gut microbiota and the immune system. Conversely, other nutritional approaches, such as Mediterranean diet (MD), positively influence immune system and gut microbiota, and is proposed not only as a potential tool in the clinical management of different disease conditions, but also for prevention and health promotion globally. Thus, the purpose of this review is to determine the regulatory role of nutritional components of WD and MD in the gut microbiota and immune system interplay, in order to understand, and create awareness of, the influence of diet over both key components. 
Keywords: gut microbiota; host immunometabolism; intestinal barrier; mediterranean diet; western diet; immunomodulation; food matrix; micronutrients; malnutrition

\section{Introduction}

The term microbiota refers to the set of microorganisms that inhabit superior organisms, including human beings, constituting a unique entity named a holobiont [1]. During the last few decades, interest has been growing in the knowledge of the microbial ecosystem, as it is a crucial component of the individual's health, keeping a homeostatic balance with the host [2]. Recent advances in sequencing techniques are playing a critical role in the study of the relative abundance of microorganisms in the different environments of the human body, bacteria being the most common members of the microbiota (90\%), although viruses, fungi, archaea and even protozoa have also been detected. Even so, the complete microbial structure is far from complete elucidation [3]. Not only are the populations of microorganisms important points of study, but so too are their genome and the end-products of their metabolism, all of these being collected under the term microbiome [4]. Microorganisms have been identified in various locations of the human body, such as the oral cavity, upper airways, genito-urinary tract and skin. However, it is in the gastrointestinal tract, and particularly in the gut, where they are most relevant, and are directly related to a broad spectrum of pathologies [5].

The important effects of gut microbiota in the organism are partly due to the tight relationship sustained with the host's immune system from the early stage [6]. This interaction is bidirectional and dynamic, equally representing a key part of the knowledge of the different homeostatic and pathophysiological conditions [7]. Scientific evidence has supported the direct influence of diet in the gut microbiome and immune system, and a large number of studies are being developed to modulate both components, this balance being considered a central aspect of precision nutrition [8,9]. In addition, interventional nutrition is another study issue, offering to people with established pathologies such benefits as probiotics, prebiotics or bioactive compounds, providing a potential approach to influence the microbiota-immunity dialogue [10]. Thus, the purpose of this study is to review the impact of nutrition and diet on the gut microbiota-immune system communication, exploring the basis of their interplay and the consequences of diet in this relationship.

\section{The Human Gut Microbiota}

\subsection{Structure, Diversity and Dynamics of the Gut Microbiota}

As previously reported, all domains of microorganisms compose the gut microbiota, including bacteria, archaea, viruses, fungi and protozoa. According to the current evidence, the ratio found between microorganisms and human cells is approximately 1:1 $\left(3.8 \times 10^{13}\right.$ vs. $3 \times 10^{13}$ ). This relation is noticeably higher when analyzing the genomes, microbial genetic content being 100 to 200 times superior to the content of our cells [11]. More accurately, recent studies have quantified the bacterial genes in the gut, finding up to 22 million genes in this location. Moreover, these genes were also determined to be different among individuals, being denominated as singletons, thus demonstrating the interpersonal phenotypic heterogeneity of the human gut microbiota [12]. Due to the representative number and the various vital functions of the gut microbiota, some works, such as the Human Microbiome Project conducted by the National Institute of Health (NIH) of the United States, have been developed to provide standardized data regarding the human microbiome in physiological conditions and diseases, recognizing a "microbial core", which is fundamental to the health of the individual [13]. Bacteria are the major components of the microbial core. In fact, up to 2776 species of bacteria have been recognized in the human gut, including 11 different phyla [14].

Firmicutes are the most extended bacterial family $(65 \%)$, followed by Bacteroidetes (23\%) and Actinobacteria (5\%) [15]. Among the Firmicutes group, it is worth noting the 
presence of type IV and XIVa Clostridia, belonging to the genus Clostridium, Ruminococcus and Eubacterium, whereas Bacteroides and Prevotella are the most important components of Bacteroidetes [16]. Frequently, the higher or lower presence of some of these microorganisms may lead to the classification of the individual's microbiota into enterotypes, which are the following: enterotype 1, with augmented levels of Bacteroides and reduced Prevotella; enterotype 2, with decreased Bacteroides and increased Prevotella, and enterotype 3 , enriched in Ruminococcus [17]. Importantly, this classification is non-exclusive, but it is useful to simplify the study of gut microbiota, keeping a tight connexion with diet or the individual's physiology [18]. The Bifidobacterium genus is the principal member of the Actinobacteria phyllum [19]. Proteobacteria is the fourth-ranked phylum in terms of abundance, characterized by its Gram-negative staining with lipopolysaccharides (LPS) in the outer membrane. In this group, the most important examples are Escherichia and Helicobacter [20]. In the same manner, other members with less abundance hold the same importance in the gut microbiota, as is the case of Akkermansia muciniphilla, the only species of Verrucomicrobia [21].

On the other hand, viruses are additional components of healthy gut microbiota, shaping what is known as the virome. The virome is equally unique and stable, and is influenced by the bacterial composition [22]. In fact, approximately $45 \%$ of mammal viruses may compose the virome of healthy individuals, with no clinical outcomes, although in other situations these viruses may interact with other microorganisms, leading to an infectious disease [23,24]. However, bacteriophages are the most abundant viruses in the gut, particularly the crAssphages, which under homeostatic conditions are usually found as inactive prophages. Even so, when having a disease status, an increased activation of the prophages and their lytic activity has been observed [25]. Plant-viruses and giant viruses may also appear in the gut virome [26]. Likewise, Archaea, mainly represented by methane-producer microorganisms from the genus Methanobrevibacter, appear to play significative roles in the regulation of microbial populations in the human gut $[27,28]$. Fungi are another component of the intestinal microbiota, whose abundance is directly influenced by bacterial interactions [29]. Finally, more complex organisms, such as protozoans and even helminths, might provide substantial interactions with the gut microbiota and host homeostasis $[30,31]$. As bacteria are the major group of microorganisms residing in the intestine, this domain will be the subject of study when referring to the gut microbiota.

It is crucial to understand that the gut microbiota represents a dynamic structure in continuous communication with the environment. To favor their ecological niches, microorganisms serve themselves via symbiotic relationships with the host, including mutualism or commensalism. In the first case, both microorganism and host are benefited, whereas in commensalism only one part is favored without harming the other [32]. In this context, a pathobiont would be a microorganism that under physiological conditions has no negative effects, but in pathological situations may be detrimental to the individual's health [33]. Likewise, microorganisms may interact among themselves, enhancing or limiting the growing of certain groups. A critical part of these intra and interspecies relationships is quorum sensing, which may determine the behavior and composition of the microbial populations $[34,35]$. Another means of communication is through the production of antimicrobial compounds, capable of inhibiting the growing of other microorganisms. It is worth noting the role of bacteriocins secreted by some species from the genera of Lactobacillus and Bifidobacterium, which negatively influence the establishment of pathogen bacteria such as Listeria monocytogenes or Clostridium perfringens [36,37]. In summary, the gut microbiota is a diverse, unique and dynamic element in the human body, and it will be essential for the physiological/pathological status of the individual.

\subsection{Eubiosis vs. Dysbiosis: The Two Edges of Microbiota in Health and Disease}

The term eubiosis is used to describe the favorable physiological status of gut microbiota, with so-called "good bacteria" that are capable of controlling "bad bacteria". 
The opposite situation, dysbiosis, could be defined as a loss of this beneficial homeostatic balance [38,39].

Under eubiosis conditions, the gut microbiota perform a broad variety of functions within the holobiont, essential for its health. This is due to the production of critical compounds such as short chain fatty acids (SCFAs), acting as local and systemic signaling molecules, with important implications in health and disease conditions [40]. The main examples of SCFAs are acetate, propionate and butyrate, obtained from the digestion of resistant starches and dietary fiber. Acetate production is widely distributed among many bacterial populations, whereas propionate and butyrate are restricted to certain microorganisms belonging to the phylum Firmicutes or Akkermansia muciniphilla [41]. Moreover, other products, such as lactate, obtained from the fermentation of non-digestible compounds of dietary fiber, could equally influence the production of propionate and butyrate [42]. Intestinal bacteria also actively participate in the metabolism of aminoacids, such as tryptophan, a critical element with important implications for the metabolism of serotonin, melatonin or kynurenine, and having consequences in other physiological processes [43]. Likewise, gut microbiota are essential for the synthesis of vitamins, such as vitamin $\mathrm{K}$ or many of those of the $\mathrm{B}$ complex, the degradation of polyphenols from the diet, xenobiotic elimination, and even the metabolism of bile acids (BA) $[44,45]$. All these components interact bidirectionally with the gut microbiota. In other words, the gut microbiota produce and control these products, and the presence of the different elements modulates the microbiota composition [46]. Some authors refer to the "phylometabolic core" instead of the phylogenetic core, as it better reflects the metabolic functions performed by certain groups of microorganisms, including butyrate or propionate producers and lactate users, as well as bacteria involved in bile acid metabolism or vitamin synthesis, and much more [47].

In the same manner, in recent years, the central role of the microbiota in gut-brain communication has been established, shaping the microbiota-gut-brain axis, as many of these metabolic products serve as a method of dialogue between both organs, indirectly through intermediate mediators, or directly by the vagus nerve and the enteric nervous system [48]. This relationship also occurs with other structures in the body, such as bones [49] or the cardiovascular system [50], thus showing the prominent effects of the gut microbiota and their metabolites on the individual's health. Thus, the gut microbiota may favorably interact with the host cells, leading to a healthy homeostatic status, or may act negatively, contributing to an inflammatory response under dysbiosis conditions. On the other hand, gut dysbiosis may play an essential role in the development of a broad spectrum of pathologies, such as neurodegenerative diseases, metabolic disorders, inflammatory and autoimmune diseases, among others [51]. Nevertheless, whether these changes are the cause or consequence of different effects remains unclear [11,52], although recent research seems to indicate that both are correct, as gut dysbiosis contributes both to a pathophysiological mechanism and the coadaptation to unfavorable conditions [53]. Accordingly, two types of dysbiosis can be distinguished: taxonomic and metabolic dysbiosis.

Taxonomic dysbiosis is manifested as a quantitative or qualitative loss of the gut microbiota's composition. This is closely associated with a reduced microbial diversity, frequently presented as an altered Firmicutes to Bacteroidetes ratio [54]. The altered proportion of both bacterial phyla has been reported in different pathologies, including infections [55] and non-communicable diseases (NCDs), such as type 2 diabetes mellitus (T2DM) and obesity, in which a simultaneous decrease in bacteria belonging to the phylum Bacteroidetes, and an increase in non-favorable Firmicutes bacteria from the genus Clostridium, has been reported [56,57]. Although many works have focused on the study of the Firmicutes to Bacteroidetes ratio, recent research shows that this imbalance is not enough to obtain a complete assessment of the gut microbial environment [58]. The complementary study of the remaining communities, such as Proteobacteria [59], Actinobacteria [60], or the less abundant but important bacteria Akkermansia muciniphilla [61], is also important in the taxonomic study of the gut microbiota. 
Similarly, metabolic dysbiosis is used to express not a change in the taxonomic composition, but an altered phylometabolic core $[47,62]$. To characterize the type of dysbiosis in each individual, different methods can be used, including techniques of metagenomic sequencing to unravel the microbiome composition [63], or metabolomic approaches such as mass spectrometry, which can be used to examine the metabolic profile, for example through fecal samples [64]. Independently from the type of dysbiosis, important alterations in the synthesis of microbial metabolites have been reported due to this altered microbiota, with negative repercussions for the host [54]. These effects of gut microbiota are mediated or influenced by the immune system, which responds in the same manner as the gut microbiota [65]. One of the most worrying effects of gut dysbiosis is the presence of a component from the outer membrane of Gram-negative bacteria in the bloodstream, known as endotoxin or Lipopolysaccharide (LPS), which is associated with chronic inflammation [66].

As such, it is crucial to describe the different cellular and structural elements in the gut ecosystem in order to understand how the gut microbiota-immune system relationship works.

\section{Integrators of the Gut Mucosa and Immunobiology of the Gut}

The gut, just like the rest of the digestive structures, is composed of different layers, including the epithelium, lamina propria, muscularis mucosa (these three layers forming a combined layer known as the mucosa), submucosa, muscularis propria, and an adventitia. Structurally, two main divisions could be distinguished: the intestinal villi, implicated in the absorption and transport of nutrients and crypts, where stem cells are located [67,68]. The large intestine does not present intestinal villi. The gut epithelium is mainly formed by the epithelial cells known as enterocytes, cells specialized in the absorption of nutrients and the entry of substances from the intestinal lumen into blood, and which thus assume a key role in the intestinal barrier and antigen uptake [69]. Globet cells are equally important elements of the gut epithelium, particularly in the large intestine, and are responsible for the production and secretion of mucine, a glycoprotein acting as a protective agent that prevents the entry and invasion of microorganisms in the different gut layers [70]. Similarly, other components of the epithelium need to be mentioned here, including tuft cells, specialized in the immune responses against eukaryotic parasites and acting as a gut microbiota sensor for the host [71,72], or the Paneth cells, specifically located in the intestinal crypts, responsible for the production of antimicrobials peptides, therefore controlling gut microbiota composition [73]. Although they are normally restricted to small intestine crypts, and at very low proportions in the first regions of the large intestine (from cecum to transverse colon), Paneth cells can also be found under inflammatory pathological conditions, such as inflammatory bowel disease (IBD), in the final portions of the large intestine, termed as metaplastic Paneth cells [74]. Enteroendocrine cells (L-cells) are hormone-producer cells, regulating the appetite, gut microbiota composition and the integrity of the intestinal epithelium [75].

Immediately under the epithelium, the lamina propria is the next layer belonging to the mucosa. Here, a plethora of immune cells are found and organized in lymphoid tissues known as GALTs (gut-associated lymphoid tissues) [76]. It is an extraordinarily complex system, that has coevolved and developed with a wide variety of microorganisms, maintaining a continuous dialogue with them, equally assuming important functions in cellular nutrition, antigen tolerance, and energy starvation in the host [77]. GALT is a type of MALT (mucosa-associated lymphoid tissue), with essential functions in gut homeostasis. The small and large intestinal surface represents a $32 \mathrm{~m}^{2}$ structure, with an estimated $10^{14}$ commensal microbes and more than $30 \mathrm{~kg}$ of food proteins measured yearly, which may be controlled and tolerated by GALT [78,79]. The number of cells in the GALT increases progressively from the duodenum to the final portions of large intestine, according to the higher presence of microorganisms. Different immune cells can be detected forming the GALT, including T and B lymphocytes, dendritic cells (DCs), and macrophages, among others. These cells are dynamically recruited from the body 
to the gut, depending on different stimuli under conditions of health and disease [80]. In addition, there are intraepithelial lymphocytes located at the intestinal epithelium, interacting with the different microorganisms and cells in the gut [81]. There are different denominations of GALT depending on the location, including Peyer's, cecal, or colonic patches. In communication with GALT, in the follicle-associated epithelium overlying the surfaces of intestinal lymphoid tissues resides an additional cellular type named microfold (M) cells [82]. M cells play a key role in the capture and translocation of microbes and molecules from the intestinal lumen, subsequently recognized by DCs, then interacting with $\mathrm{T}$ and $\mathrm{B}$ cells, leading to a regulation of the inflammatory response and secretion of immunoglobulin A (IgA), thereby modulating microbial communities [83,84].

The different bacterial and eukaryotic cells in the gut are summarized in Figure 1. Now that the components of the intestinal mucosa have been identified and described, we will further explore the different mechanisms by which they interact with gut microbiota, representing a potential approach to modulating and disentangling potential mechanisms for controlling the gut microbiota and its interactions with the immune system in the gut.

\section{Basis of Gut Microbiota-Immune System Interplay \\ 4.1. Microbial Communities and Their Products}

The different cells located in the epithelium of the intestinal mucosa, along with the immune cells, contain various receptors for different molecules, known as pattern recognition receptors (PRRs), specialized in the detection of MAMPs (microbe-associated molecular patterns), and also named PAMPs or pathogen-associated molecular patterns [85, 86]. Among the most important PRRs are membrane toll-like receptors (TLR) or C-lectin receptors (CLR), and the cytosolic NOD-like receptors (NLR) [87]. Similarly, metabolic products from the microbial communities will be captured and recognized by these cells, with important implications for gut homeostasis and immunity [88]. Thus, both the gut microbiota and immune systems affect each other through bidirectional interactions. This relationship provides potential benefits to the host, for example in the education and regulation of immune functions and the formation of the intestinal barrier [89,90]. On the other hand, there is evidence supporting the interpretation that the interaction of the intestinal microbiota and the immune system cells may damage the intestinal barrier, increasing bacterial translocation with systemic pro-inflammatory effects [91]. This pathogenic mechanism has been observed in different diseases [92-94]. Here, we will summarize some of the mechanisms and signaling processes used by bacteria and the possible responses enacted by immune cells.

Some microbial products have been established to act as immune activators. For instance, LPS and its lipid A domain abundantly expressed by Gram-negative bacteria are recognized by the innate immune system, leading to a pro-inflammatory response [95]. Likewise, some types of bacteria including certain members of Bacteroidales, Erysipelotrichales, Clostridiales, and Bacillales are capable of producing capsular polysaccharides, which may encompass similar mechanisms. This is the case of polysaccharide A (PSA) located in the capsule of Bacteroides fragilis, which may be recognized by plasmacytoid DCs promoting an anti-inflammatory response in the gut [96]. The recognition of these components contributes to the release of IL-10, the most important anti-inflammatory cytokine mainly produced in the gut by $\mathrm{T}$ regulator lymphocytes (Treg) $[97,98]$. Other bacteria, such as segmented filamentous bacteria (SFBs), may have distinct effects on the immune response. SFBs are a group of bacteria bound to the intestinal epithelium in a mutualist relationship, up-taking available nutrients while releasing vital antigens with a strong immunomodulatory effect on the host [99]. Thus, SFBs are related to an immunocompetence status, and are also associated with the production of IgA by B cells in the gut [100] and even in extraintestinal locations, collaborating in the proper response against fungal pathogens in the lungs [101]. These effects are coordinated by Th17 cell polarization, which is key to maintaining host homeostasis $[102,103]$ 


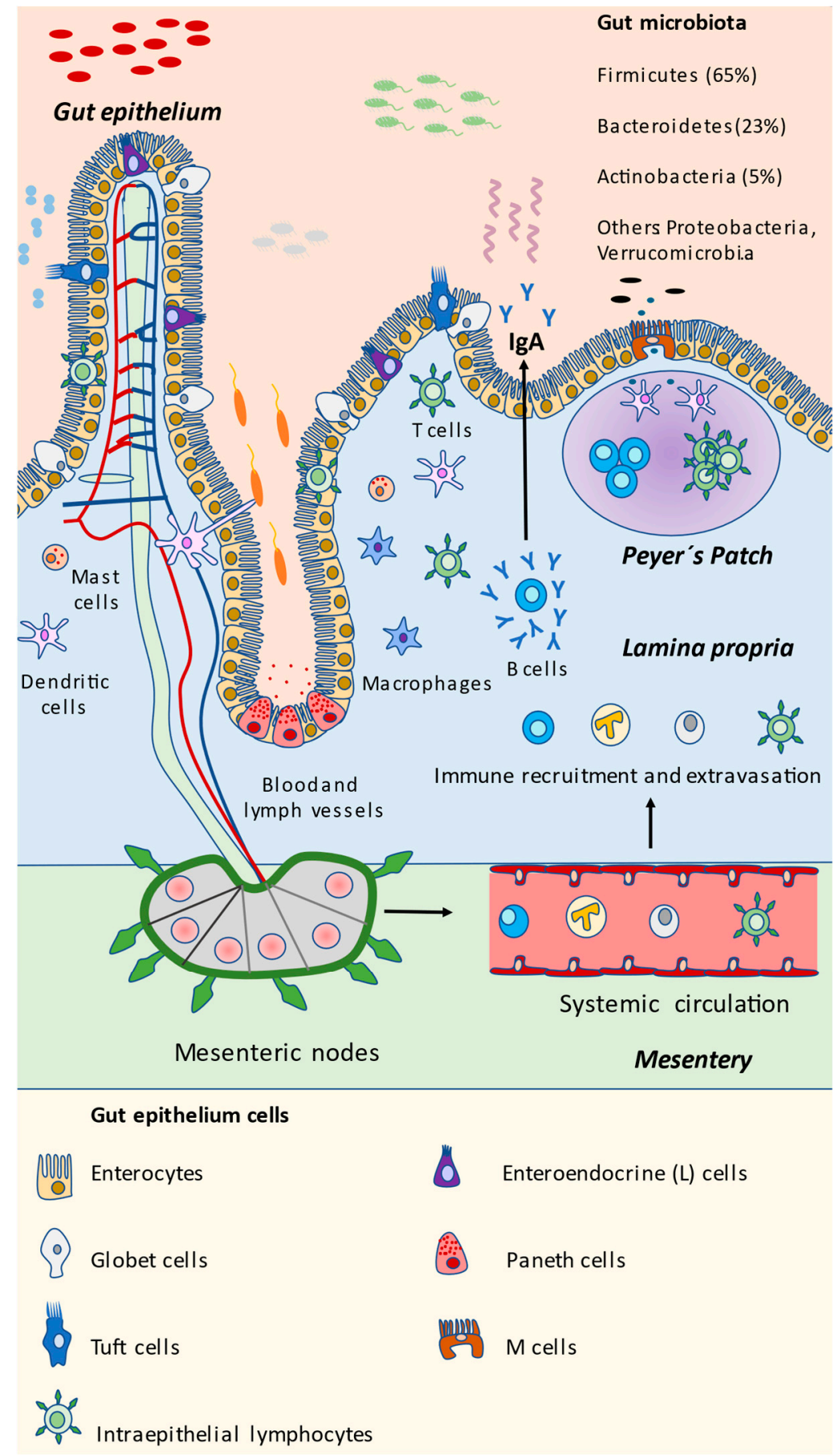

Figure 1. Microbial and eukaryotic components of the gut. As represented in the scheme, gut mucosa is a highly dynamic structure in which microorganisms and epithelial and immune cells are interacting continuously. The gut microbiota is mainly composed of the Firmicutes phylum, followed by Bacteroidetes, Actinobacteria, and other bacteria that are less abundant but equally important, including Proteobacteria and the Verrucomicrobia Akkermansia muciniphilla. Immune detection and response may be assessed at the local Peyer's patch present in the small intestine, or through mesenteric nodes, activating immune cells and accessing the gut through the bloodstream, finally promoting the release of IgA by plasmatic B cells. Other cells may aid in the capture of microbial antigens, coordinating the immune response, including tuft cells, $\mathrm{M}$ cells and even intraepithelial lymphocytes. Paneth cells prominently act through the release of antimicrobial compounds. Enterocytes and globet cells play a key role in maintaining the intestinal barrier, whereas enteroendocrine cells produce certain products that are essential for metabolism and the individual's health. 
The balance between different $\mathrm{T}$ cells populations appears to play a central role in the physiological and pathological conditions. For example, the balance between Treg lymphocytes (anti-inflammatory) and Th17 (pro-inflammatory) cells is vital for a proper inflammatory response, and it is prominently modulated by the gut microbiota [104]. Thus, a disruption in this balance, with reduced Treg and increased Th17, may be associated with intestinal pathology [105] or autoimmunity [106]. Similar to SFBs, there are other bacteria that may present immunomodulatory properties via adhesion to the intestinal epithelium cells, such as Bifidobacterium adolescentiis, Escherichia coli O157 or Citrobacter rodentium, which equally induce Th17 differentiation $[107,108]$.

Other critical microbial populations include the bacteria from the genus Alcaligenes. Alcaligenes are opportunistic bacteria residing in the GALTs, similar to those in the Peyer's patch, where DCs recognize their LPS through TLR-4 activation to foster the activity of IL-6 and IgA production [109]. Regardless of the fact that the systemic presence of LPS in the bloodstream (endotoxemia) is related with chronic inflammation [110], the presence of Alcaligenes in the GALT means that LPS interacts symbiotically with DCs in healthy individuals [111]. In addition, other bacteria, such as Clostridia, are a class of bacteria belonging to the phylum Firmicutes, and clusters IV and XIVa represent an important part of the healthy gut microbiota (10-40\%), with important implications for the host [112]. These clusters, along with the XVIII, play a prominent role in the induction of Treg cells in the gut, thus promoting anti-inflammatory effects [113]. Nevertheless, there are other members of Clostridia, such as Clostridium difficile, that are not favorable for the immune system, the most common being those associated with dysbiosis [114].

Likewise, the activation of NLRs plays a prominent role in the regulation of microbial signatures. For instance, some members of this family, NOD-, LRR (leucine-rich repeat)- and pyrin domain-containing 6 (NLRP6) and NLRP3, are able to form multiprotein signaling complexes known as inflammasomes [115]. Multiple cells in the gut present inflammasomes, the activation of which is regulated by gut microbiota, thereby promoting the release of IL-1 $\beta$ and IL-18, pro-inflammatory cytokines responsible for antiviral responses in the gut or mucus secretion by globet cells, among other things [116]. It seems that the activation of the inflammasome is an essential form of communication between the host's immunity and the pathobionts in the gut microbiota, such as Proteus mirabilis or Helicobacter pylori $[117,118]$. On the other hand, a deficiency in the inflammasome also promotes the overgrowth of certain microbial communities, meaning it is associated with intestinal inflammation $[119,120]$.

The other bacteria playing a critical role in host homeostasis include Akkermansia muciniphilla, a special member of the gut microbiota involved in innate immunity [121] and in the adaptative immune response [122], increasing the levels of IL-10, and modulating T cells fate and IgG1 levels depending on individual characteristics, the composition of the gut microbiota and the interaction with additional environmental factors. This behavior is similar to those seen in beneficial bacterial strains, such as Faecalibacterium prausnitzii A2-165 and Lactobacillus plantarum WCFS1 [123,124].

Finally, some probiotic bacteria, such as Lactobacillus rhamnosus GG, Lactobacillus casei Shirota, Bifidobacterium animalis Bb-12, Lactobacillus johnsonii La1, Bifidobacterium lactis DR10, and Saccharomyces cerevisiae boulardii, are powerful inductors of the immune response, activating a wide variety of immune cells in a strain-specific and dose-dependent manner [125]. Due to their immunomodulatory properties, probiotics have been proposed as a potential adjuvant in certain pathologies, including cancer [126] or colitis [127], and even in healthy aging [128], supporting the use of these microorganisms for controlling the immune system. As a result, gut microbiota bacteria are thenceforth recognized by immune cells, leading to a proper response and the maintenance of gut homeostasis.

\subsection{Microbial Metabolites}

On the other hand, some microbial metabolites are components of note in the microbiotaimmune system dialogue. SCFAs are components with powerful immunomodulatory prop- 
erties. In the gut, enterocytes present different receptors to permit the entry of SCFA, which will be used in part to obtain energy by these cells [129]. Furthermore, SCFAs induce the release of TGF- $\beta$ and IL-18 in the enterocytes, which are key activators of the inflammasome NLRP3 [130,131]. Moreover, there are also SCFA receptors expressed in the basolateral membrane, favoring the passage of SCFA to be distributed locally and systemically. In the gut, SCFAs may be recognized by G protein-coupled receptors (GPCR) such as FFAR-2, FFAR-3, GPR-41, GPR109A or Olfr78 [132]. This interaction will promote downstream cellular signaling, thereby regulating different products, such as hypoxia-inducible factor (HIF), collaborating with intestinal integrity and the production of antimicrobial substances by the Paneth cells [133]. In the same manner, SCFAs regulate the secretion of mucine by globet cells, or the release of GLP-1 (Glucagon-Like Peptide 1) and the peptide YY by L-cells, with important consequences for intake and insulin production [134]. In the immune cells, SCFAs have important effects on both innate and adaptative cells, leading to increased levels of IL-10, Treg and Breg cells $[135,136]$. Other studies have reported a boosted Th1 polarization in a non-pathological context, equally reducing Th17 levels [137]. On the other hand, gut dysbiosis may promote an increased Th1/Th17 balance, leading to IBD [138]. SCFA are also associated with the local production of IgA by B cells and with IgG systemically [139]. Besides this, SCFAs promote the activation of the histone-acetyl transferase (HAT) and the inhibition of the histone deacetylase enzyme (HDAC). Thus, SCFAs act as an epigenetic mechanism in the host, promoting an anti-inflammatory phenotype in the gut through the inhibition of the nuclear factor kappaB (NF-kB) [140]. On the other hand, the role of SCFA remains to be systemically elucidated. Recent works have shown that SCFA could activate the MAPK pathway, activating NF-kB and therefore presenting the opposite effects, favoring the overproduction of pro-inflammatory cytokines [141]. Importantly, this action is typically associated with pro-inflammatory molecules such as LPS or TNF- $\alpha$. Thus, the global beneficial or detrimental effect of SCFA will depend on different factors, such as the eubiotic/dysbiotic status.

Another key molecule in the gut microbiota-immune system dialogue is BA. BAs are produced by the hepatocytes and stored in the gallbladder. Then they are released in the gut, facilitating the emulsion, absorption, and digestion of fats. BAs are molecules derived from cholesterol, forming two main types of primary BA: cholic acid (CA) and chenodeoxycholic acid (CDCA) [142]. Then, primary BAs will be biotransformed by the gut microbiota, interacting with the farnesoid X receptor (FXR) or the G-protein coupled bile acid receptor 1 (GPBAR-1/TGR-5) [46], although it has been observed that secondary BA present a higher affinity with GPBAR-1 [143]. The different cells in the gut present both receptors in their membrane, having important immunomodulatory activity. For instance, BAs promote an anti-inflammatory M2 macrophage phenotype and reduce the M1 pro-inflammatory phenotype either in the gut or liver, with an increase in IL-10 levels and decreased IFN $\gamma$ and IL-6 [144]. Simultaneously, secondary Bas such as taurine are powerful modulators of the NLRP3/NLRP6 inflammasome $[145,146]$. Other studies have shown the role of secondary BAs in the adaptative immune system, mainly through the regulation of the Treg/Th17 ratio [147,148] and Th1 populations [149]. BAs, in turn, act as important modulators of gut microbiota, acting in fact as antimicrobial compounds [150]. Alterations in the production of BA have been associated with dysbiosis conditions, leading to a loss of intestinal integrity, augmented bacterial translocation and the pathogenesis of inflammatory diseases [151-153]

Finally, tryptophan derivatives play a prominent role in the immunomodulatory capacity of gut microbiota. The tryptophan metabolism could be divided into three distinguished paths: (1) the kynurenine pathway, (2) serotonin synthesis and (3) the formation of tryptamine and indolic compounds [154]. Indole-derivatives and tryptamine have been proposed, and are considered critical products in the homeostasis of epithelial and immune cells in the gut, acting through the Aryl hydrocarbon receptor (AhR) [155]. The activity of indolic compounds synthesized by gut microbiota such as Lactobacillus sp. could stimulate the production of IL-22, thereby assisting the immune response against fungi such as 
Candida albicans [156]. In the same manner, indolic metabolites may promote the reprogramming of Th17 to Treg cells and other populations of adaptative and innate cells [157-159]. Ethanol-induced dysbiosis is associated with lower levels of indole-3-acetic acid (IAA), and indolic derivatives, leading to a reduced IL-22, hence promoting bacterial translocation and liver disease [160]. Importantly, some microbial species could also be involved in tryptophan synthesis, as well as participating in the formation of serotonin through this metabolite and in the regulation of systemic levels of tryptophan and the kynurenine pathway [161]. This could have important implications systemically, in different regions, including the brain or cardiovascular system $[162,163]$.

Overall, the presence of certain types of microorganisms and their metabolites seems to be critical for host homeostasis and immunity, as summarized in Figure 2. Diet is a central regulator of both gut microbiota and immune cells. Thus, unraveling the connexion between nutrition, gut microbiota and immune system is essential in order to understand the link between the gut microbiota and the immune system

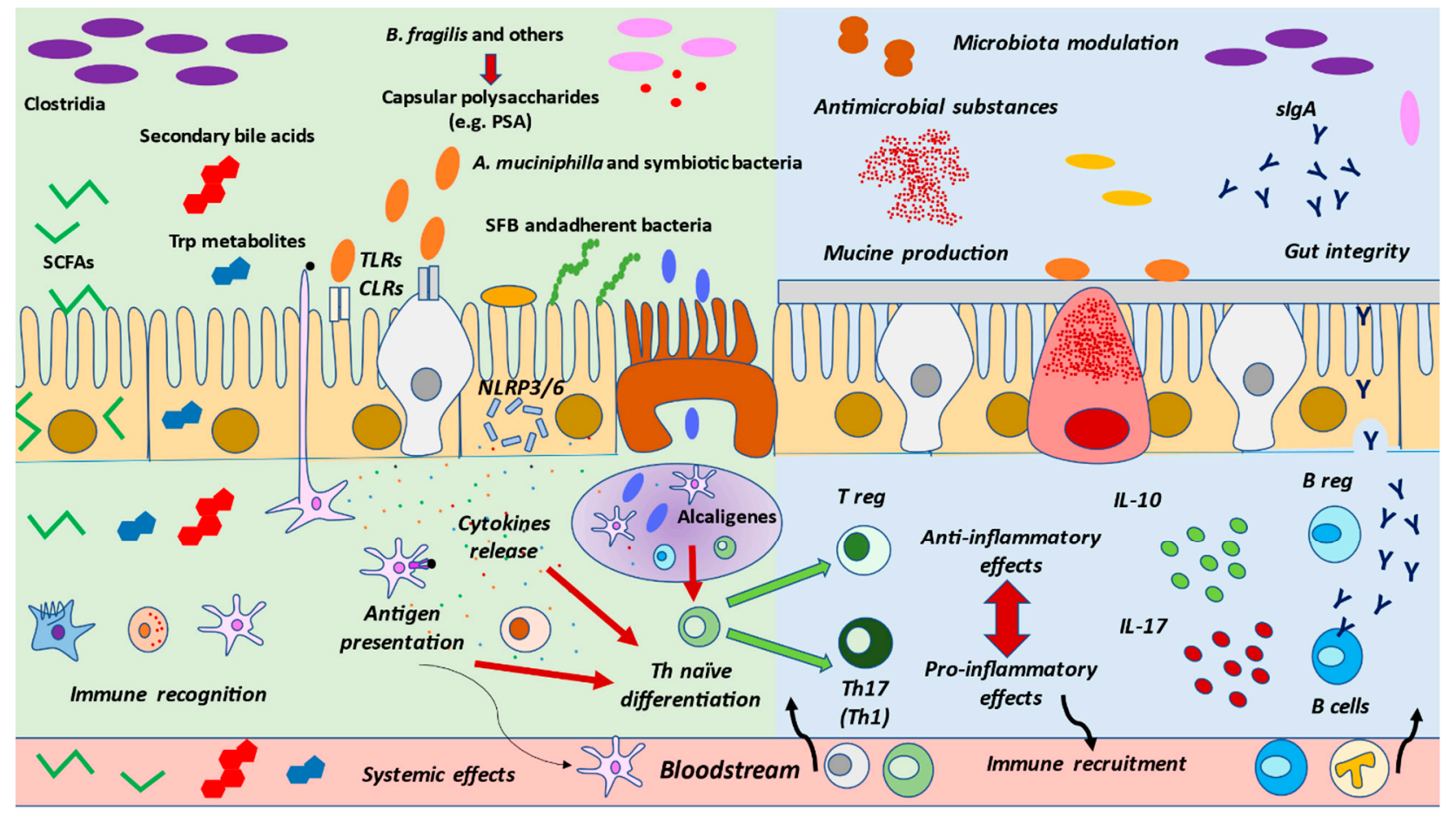

Figure 2. Interactions between gut microbiota and immune system. The presence of healthy gut microbiota, their products and metabolites are detected by the different cells located in the gut mucosa. DCs may up-take antigens and present them, as previously commented on, at the Peyer's patch or mesenteric node, leading to Th naïve differentiation. Certain bacteria such as Alcaligenes may be found in the Peyer's patch that equally regulate Th fate. Finally, some other bacteria may adhere to the epithelium, promoting the release of cytokines to modulate the immune response. These recognitions are mainly due to Toll-like receptors or Nod-like receptors, leading to inflammasome NLRP3/NLRP6 activation. Then, in gut eubiosis, the activated cells will conduct a proper response, which includes increased mucine production by globet cells, an augmentation of tight junctions by enterocytes, and the secretion of antimicrobial substances by Paneth cells or of IgA by B cells. Likewise, the balance between Treg/Th17 and pro-inflammatory and anti-inflammatory cytokines is vital for the regulation of immune responses, collaborating with an adequate, non-exacerbated response, but also with tolerance. Importantly, under pathological conditions, this balance is lost, and an inflammatory environment is created, contributing to the normal functioning of these cells, along with the associated gut dysbiosis.

\section{Diet as the Main Modulator between Gut Microbiota and Immune System: Implications in Health and Disease}

Diet is being described in the scientific literature as the most characterized factor that shapes gut microbiota and immune system, but other lifestyle factors should not be 
omitted, as well as exercise [164] and circadian clocks [165]. Diet has a rapid effect on gut microbiota composition, which promotes the growth of certain bacterial groups over others, as well as changes in intestinal $\mathrm{pH}$, intestinal permeability, bacterial metabolites, and thus inflammation [63,65]. Macronutrients, in particular carbohydrates, seem to be the best described, whereas protein and fat hits are less well defined [166]. However, micronutrients are not a minor point to contemplate, given that vitamins deficiencies, for instance, alter barrier function and immune response in the GALT [167].

Immune system and microbiome interactions go together with diet. Human evolution has played a central role in these adaptations. However, it is important to understand that these changes should not be ascribed to certain foods or macronutrients, but to the entire diet composition, along with a higher consumption of plant-based sources $[168,169]$. Thus, malnutrition in occidental countries contributes to a state of chronic inflammation and metabolic problems, whereas the typical undernourishment of underdeveloped countries leads to nutritional deficits, and therefore immunodeficiencies [170].

For that reason, nutritional intervention has been proposed as a potential therapeutic approach, targeting both gut microbiota and the immune system [171]. As diet might be an easily malleable factor, diverse studies discuss the relevance of immuno-nutrition, which consists of modifying nutrient supply to modulate immune responses [172]. This is due to data collected from both nutritional intervention and observational studies, which show that nutrients alter immune biomarkers [173]. These days, these kinds of study are becoming more prevalent on account of the COVID-19 pandemic situation, which also proves that malnutrition contributes to a greater difficulty in recovering from infections [174,175], as well as to barrier function [176], where the microbiota status plays a key role in the immune response, even in these respiratory infections [177]. In general, diet induces changes, which could be referred to as nutritional programming, in the gut microbiota besides the metabolic and immune function [178]. In this context, the pathologies related to metabolism strongly depend on food intake, which is subject to the gut-brain axis that modulates appetite control [179], as well as to the microbial metabolites that interact with the satiety pathway, and in particular with hypothalamic neurons [180].

In addition, not only may nutritional modulation serve as an adjuvant treatment for diseases, but it also may contribute to prevention, or simply guarantee a better quality of life in healthy populations [8]. Animal models and 16S rRNA sequencing have allowed us to observe microbial diversity. Nevertheless, these studies have also demonstrated that changes in bacterial communities are much greater in the small intestine than feces when feeding animals with different diets [181], something particularly difficult to handle in humans.

In summary, dietary components can have a direct effect on the barrier added to gut microbiota populations and host metabolites, therefore modulating the immune system in the host [182]. However, it is important to understand that rather than the quantity, the quality of food and its nutrients is assumed to be the most determinant factor in a healthy/unhealthy diet. For instance, occidental diets are rich in refined and unhealthy products, and are poor in micronutrients such as vitamin A or D, and fiber, provoking the weakness of tight junctions and long-term inflammatory responses [183]. In contrast, the benefits of some functional components found in healthy diets, such as probiotics, prebiotics and polyphenols, are pursued in the restoration of gut health in disease [184]. All these components' effects will be described with more detail below, in the context of a healthy model of dietary pattern (Mediterranean diet (MD)) versus an inadequate one (Western diet (WD)), in order to fully understand the role of different nutritional components in the gut microbiota and immune system's interplay.

\section{Mediterranean Diet as a Model of Healthy Eating}

MD every time shows more scientific evidence about its effects and benefits. This diet is characterized by a combination of highly complex carbohydrates in fiber (found in cereals, legumes, vegetables, fruits), polyunsaturated fatty acids with antiatherogenic and 
anti-inflammatory properties (found in olive oil and nuts), and bioactive compounds with antioxidative properties such as flavonoids, phytosterols, terpenes and polyphenols [185]. Similarly, a perfect balance of micronutrients, which are abundant in this diet, including vitamins and minerals, help avoid malnutrition and immunodeficiencies $[186,187]$. The immune system needs to cooperate with a group of substances to correctly perform its functions, and some of them are required in higher concentrations depending on the health status and the patient [188].

Nutrient-rich foods allow the body to repair inflammation triggered by nutrient-poor and high-calorie diets, contributing to attenuating cardiovascular risk factors [189]. Moreover, adherence to MD correlates with microbiota eubiosis reestablishment as Bacteroidetes and certain beneficial Clostridium groups grow, whereas Proteobacteria and Bacillaceae phyla decrease [183]. Thus, as the gut microbiota represents an indicative factor as regards the individual's health status, it is also a factor that denotes adherence to a healthy type of diet, such as MD [190].

In certain trials from the PREDIMED (PREvención con DIeta MEDiterránea) study, gut microbiota status in feces was evaluated in the context of adherence to MD and nutrients consumption through $16 \mathrm{~S}$ rRNA sequencing and quantitative PCR (qPCR) for metagenomics, and through high-performance liquid chromatography (HPLC) for metabolomics (mainly SCFAs analysis). The results showed that participants who consumed a greater amount of animal protein presented a higher Firmicutes:Bacteroidetes ratio and worse adherence to MD, whereas those who consumed less animal protein had a higher concentration of Bacteroidetes and a lower ratio, as well as better adherence to diet. Participants that consumed more polysaccharides and plant proteins showed higher concentrations of SCFA and better adherence [191].

WDs promote a pathological microbiota status, leading to an increase in Firmicutes:Bacteroidetes ratio, which can be attenuated by MD as the favorable bacteria and their metabolites' production rises, whereas dysbiosis and LPS levels decrease. This fact is important in the management of certain pathologies from the dietary point of view, making MDa strategy to modulate host microbiota, causing different local and systemic responses [57]. This type of dietary pattern also associates with greater diversity, and better gut barrier function and permeability, than is seen for occidental patterns [192].

In fact, several nutritional intervention trials based on MD have collected the most relevant adaptations that this diet induces, including the following: reductions in lipid levels in serum; protection against oxidative stress; reductions in inflammation; platelet aggregation; modulation of hormones and growth factors implicated in cancer pathogenesis; and modulation of microbial metabolism, promoting the proper functioning of the host metabolism as well [193]. Nowadays, further work is being performed in order to prevent cancer, cardiovascular disease (CVD), and metabolic, or even infectious, diseases. Here, we will summarize the effects of the most relevant components of MD on the gut microbiota and immune system modulation.

\subsection{Monounsaturated and Polyunsaturated Fatty Acids}

As a common characteristic of MDs, it is worth noting the abundance of monounsaturated fatty acids (MUFAs), and polyunsaturated fatty acids (PUFAs), with a very low consumption of saturated fatty acids, which has important consequences for both gut microbiota and immune system [194]. The largest known MUFA is oleic acid, which is found in the central component of MD extra virgin olive oil (EVOO). MUFAs are the main component of EVOO, representing an estimated proportion of 70 to $85 \%$ of the total content, and oleic acid occupying around 63 to $80 \%$. Similarly, it also effects other MUFAs, such as palmitoleic acid, saturated fatty acids such as palmitic acid, or PUFAs, including linoleic acid (omega 6) and linolenic (omega 3), to quite a reduced extent [195]. Additionally, EVOO is enriched in other elements that will be subsequently discussed, such as polyphenols, carotenoids and tocopherols, fostering the expansion of beneficial bacteria $[196,197]$. Among these benefits, the high consumption of EVOO is known to boost 
lactic acid bacteria (mainly Bifidobacterium and Lactobacillus) and their bioactive metabolites in GALT, leading to a decrease in IL-6, IL-17A, TNF- $\alpha$, IL-1 $\beta$, COX-2, LDL-c, oxidized LDLc (ox-LDL) and blood pressure [197,198], as well as modulating microbiota metabolism, encouraging butyrate production, possessing anti-inflammatory and atheroprotective properties [199], and protecting colonocytes against oxidative stress [200]. In the same manner, the positive effects of oleic acid on liver dysfunction and gut inflammation have been demonstrated [201]. Accordingly, MUFA should be recommended for healthy gut microbiota and immune system. However, despite its favorable effects, an excessive amount of MUFA may negatively alter the gut microbiota, decreasing the total number of bacteria [202].

PUFAs are another key element of MD, prominently represented by omega 3 and omega 6 fatty acids. Both are considered essential fatty acids and master regulators of the inflammatory response [203]. Importantly, PUFAs are key elements of the human membranes, and dietary intake of these fatty acids may have important consequences for health and disease [204]. Omega 3 fatty acids are extensively found in fish and seafood, nuts and seeds, plants oils, and fortified foods such as eggs or dairy products [205]. Omega 3 fatty acids include alpha linolenic acid (ALA; 18:3 $\omega-3$ ), and their derivates, stearidonic acid (SDA; 18:4 $\omega-3)$, eicosapentaenoic acid (EPA; 20:5 $\omega-3)$, docosapentaenoic acid (DPA; 22:5 $\omega-3$ ), and docosahexaenoic acid (DHA; 22:6 $\omega-3$ ) [206]. On the other hand, omega 6 is highly concentrated in vegetable oils, nuts, seed, and soy derivates such as tofu, eggs or poultry. Linoleic acid (LA; 18:2 $\omega 6$ ) and arachidonic acid (ARA; 20:4 $\omega-6$ ), which may be synthesized by proper LA or found in food sources [207]. Importantly, ARA is considered a precursor of pro-inflammatory molecules, including eicosanoid hormones, prostaglandins or leukotrienes, although the role of this omega 6 acid as a pro-inflammatory or antiinflammatory component is controversial [208]. It seems that the global effect depends directly on the interaction with omega 3 fatty acids. It is assumed that a low omega 6:omega 3 ratio (no greater than 4:1) is related with anti-inflammatory effects in the immune system [209]. MD positively influences omega 6:omega 3 ratio, within a ratio of 2:1 to 1:1 maximizing the benefits of these essential fatty acids [210].

In this context, it is known that the gut microbiota are positively favored by the high presence of omega 3 PUFAs, balancing the Firmicutes:Bacteroidetes ratio and increasing favorable bacteria from the Lachnospiraceae and Bifidobacteria families, while limiting the growing of LPS-producing Enterobacteria, and thus having positive effects on the anti-inflammatory properties [211]. Moreover, it seems that gut bacteria are able to metabolize PUFAs, forming a broad spectrum of products that some authors considered microbial metabolites [212], such as CLA (conjugated linoleic acids), CLnA (conjugated linolenic acids), and non-conjugated fatty acids, such as vaccenic acid (trans-11-18:1). In fact, the capacity of the gut microbiota to inhibit the metabolized PUFAs from the diet is associated with a decreased risk of obesity and inflammation [213]. Roseburia spp. is an important member of the microbiota-metabolizing omega 6 fatty acids, and helps to to obtain CLA. Similarly, CLA formation occurs naturally in ruminants, in a process known as biohydrogenation, which permits the presence of this metabolite in meats and dairy products [214]. Then, CLA is recognized by the immune cells, enhancing the function of Treg [215]. In the same vein, Lactobacillus plantarum was found to produce CLnA, and to have important effects on gut microbiota composition by increasing Ruminococcus and Prevotella, leading to a reduced level of pro-inflammatory cytokines (TNF- $\alpha$, IL-1 $\beta$, and IL-6), and augmented expressions of anti-inflammatory IL-10 and the nuclear receptor peroxisome proliferator-activated receptor- $\gamma(\operatorname{PPAR}-\gamma)[216]$

\subsection{Fruits and Vegetables Rich in Polyphenols}

Polyphenols are a group of secondary plant metabolites, divided into two subgroups, flavonoids and non-flavonoids [217], presenting antioxidant and anti-inflammatory properties, with effects on gut microbiota as well [218]. Soy isoflavones, cocoa flavanols, blackberry and raspberry anthocyanins, tea or nuts tannins, and a long list of polyphenols, boost 
the growth of beneficial symbionts such as Lactobacillus sp. [219], and inhibit opportunistic pathogens such as Enterococcus caccae [220]. Data collected from preclinical and clinical studies suggest not only an interference in quorum-sensing, but also the prebiotic effects of these phytochemicals in relation to beneficial bacteria, encouraging them to produce antimicrobials against pathogenic bacteria [221]. The tight junction dynamics in the epithelial barrier may be altered by interactions with different phenolic compounds: where some of them promote the expression of tight junctions, others reduce it, and both events contribute to the integrity of the semipermeable character [222]. In addition, polyphenols have been recently identified as a key modulator of tryptophan metabolism by the gut microbiota, which may aid in the clinical management of certain pathological conditions [223]

One of the main characteristics of MD is the abundance of fruits and the availability of aromatic plants and spices to season food (dried herbs such as oregano, rosemary, thyme, etc.), besides seeds (cumin, sesame, etc.), olives, and nuts, all of them being rich in a wide variety of polyphenols. In the extensive group of phenolic compounds, there are three relevant components of the MD to mention: hydroxytyrosol (HT), which is found in EVOO, resveratrol (RSV) in red grapes, and quercetin (QUE), which is contained in onions, broccoli, apples, citrus fruits and other fruits and vegetables.

HT is a phenolic phytochemical with antioxidant and anti-inflammatory properties that have been proven in clinical trials, having a positive impact on CVD prevention [224]. It has been observed that a higher concentration of HT contributes to a significant decrease in oxidized LDL and triglycerides, with a minor expression of oxidative stress-related genes as well [225]. HT is still being studied as a nutraceutical in high-fat diet (HFD)-induced obese mice models, used to visualize the reversion of inflammatory parameters (elevated TNF- $\alpha$, IL-1 $\beta$, IL-6) by this specific EVOO component, and also the inhibiting of the activation of TLR-4 and NK-kB pathways typical to intestinal permeability in obesity [226]. Likewise, the phenolic compounds found in EVOO, such as HT, promote the growth of Bifidobacteria, which are in part responsible for the anti-inflammatory properties in the gut [227]

RSV is a potent antioxidant and anti-inflammatory, and one of the more favored nutraceuticals these days. This nutraceutical in the gut is partly transformed by bacteria, and its derivatives are conjugated in the liver, as well as in glucuronidation and sulfation processes [228]. RSV, microbial metabolites and conjugated products can target different oxidative stress-related factors, inhibiting NF- $\mathrm{kB}$ and activating nuclear erythroid 2-related factor 2 (NRF2) [229], which are particularly implicated in aging [230]. RSV targets several inflammatory, metabolic and epigenetic components, and a wide range of the antioxidant enzymes implicated in gluconeogenesis, lipid metabolism, mitochondrial biogenesis, angiogenesis and apoptosis. It may block TLR4, silence pro-inflammatory genes, reduce Th17 cells and IL-17, and inhibit eicosanoid production [231]. The effects of RSV on gut microbiota have been more extensively studied in mice models. In HFD-induced obese mice, the supply of RSV denotes a decrease in the Firmicutes:Bacteroidetes ratio, avoiding Enterococcus faecalis expansion and allowing Lactobacillus and Bifidobacterium proliferation [232].

QUE, as another emblematic agent from bioactive compounds, also has multiple operational effects, including anti-carcinogenic, anti-inflammatory, antiviral, and antiplatelet-aggregation [233]. Animal models have helped us to describe the immune signaling pathways in which QUE interferes, including the inhibition of LPS, NO, $\mathrm{PGE}_{2}$, iNOS, COX-2, TNF- $\alpha$, IL-1 $\beta$ and IL-6 [234], and impeding Th1 differentiation in the autoimmune disease model, but generally avoiding the accumulation of inflammatory and anti-inflammatory cells [235]. Translational research highlights its potential for use against allergies, since it may modulate Th1/Th2 balance and limit antibodies formation, and inhibit IL-8 production and histamine liberation [236]. As regards microbiota, the effects are still being studied in animal models. In colitis-affected feces from mice, the effects of QUE supplementation were observed: microbial diversity increased, the expansion of Bacteroides was promoted, and Bifidobacterium, Lactobacillus and Clostridia, acting against the reduction of Enterococcus, we promoted too [237]. The combination of diverse phytochemicals can boost their antioxidant and anti-inflammatory properties, as has 
been reported in some rodent models. The supply of a mix of QUE and RSV has been observed to increase microbial diversity, ameliorating dysbiosis as well as mitigating serum inflammatory markers [238].

\subsection{Dietary Fiber}

Dietary fiber consists of a complex of carbohydrates that are not digestible by our gut cells, but which have prebiotic effects, meaning bacteria do ferment them, giving SCFAs as the fermentation metabolites. These food components resist digestion in the small intestine, and engage in in microflora fermentation when arriving at the colon.

In particular, the microbiota-accessible carbohydrates (MAC) contained in dietary fiber are the dietary components used by gut microbiota [239]. Indeed, MACs play a key role in the moulding of the gut microbial ecosystem; in contrast, low-MAC diets, such as WD, entail a loss of diversity [240]. Refinement in the food industry is a mistake when quality nutrients are removed, including the loss of fiber, polyphenols, and even micronutrients [241], as opposed to an MD, in which whole-grain cereals, vegetables and fruits have plenty of prebiotics [192]. Higher intakes of fiber correlate with lower arterial blood pressure and the attenuation of cardiovascular risk factors [242], a lower risk of T2DM and some cancer types (especially colorectal, gastric or esophageal), and also mortality above all [243]. Primarily, they stimulate the growth of Bifidobacteria and Lactobacilli, lifting their metabolism, and hence strengthen the gut barrier, contributing to GALT homeostasis [244].

Nevertheless, there are different types of dietary fiber, with correspondingly different physiological effects: insoluble (nonviscous) fiber, predominantly in cereal, and soluble (viscous) fiber, in fruit. The first one involves a greater addition of water to stool, with a laxative effect that the latter (which is more easily fermentable) does not offer; however, it does permit a better cholesterol lowering effect [245], but does not seem to reduce T2DM risk as much as the insoluble alternative [246]. Cereal fiber's benefits reside in improved colonic fermentation, aiding glucose tolerance and reducing inflammation [247]. Both kinds are necessary in a balanced diet, and recommendations should be oriented towards the patients' particular health status requirements. Another fact is the interference in energy balance and insulin homeostasis, as carbohydrates rich in fiber are low-glycemic [248].

Several controlled trials have proven that, even in the short term, the supply of fiber to individuals that have consumed high-fat and high-carbohydrate diets was able to reduce inflammatory parameters, avoiding the increase in HFD-induced LPS [249].

$\beta$-Glucans are the principal soluble fiber, and are the polysaccharides abundant in oat grain and in barley or wheat. Most evidence suggests that they increase the satiety sensation, and thus seems to contribute to adequate body weight control [250]. In vitro and in vivo models describe their interactions with TLR4, inducing DC maturation and attachments with other receptors on macrophages, in both inducing cytokines production, and triggering the activation of $\mathrm{T}$ and $\mathrm{B}$ cells [251]. The enhanced immunomodulatory operations start with major SCFA production, with effects on immune cells [252]. Moreover, they show antioxidant properties by reducing oxidative stress [253]. On the other hand, other common soluble prebiotics are oligosaccharides, including inulin, oligofructose (OF), lactulose, fructooligosaccharides (FOS), galactooligosaccharides (GOS), dextrin, etc., with increasing evidence of their anti-inflammatory potential. Some recent trials have showed that inulin supplementation lessens LPS and TNF- $\alpha$ in T2DM [254], and limits presentation of metabolic syndrome (MetS) [255]. In contrast, some studies showed that only FOS and GOS supplementation may decrease certain butyrate-producing bacteria, such as Phascolarctobacterium sp. or Ruminococcus sp. [256]. Therefore, targeting the gut microbiome for nutritional intervention, the question involves finding a balance of those fiber components in order to reach the desired beneficial effects individually.

Some non-digestible carbohydrates, such as cellulose, increase gut transition, reducing the time of colonic fermentation, and contribute to sustaining a wider microbial variety [257]. Furthermore, polysaccharides have effects on glycometabolism-related dis- 
eases [258], interacting with bacteria and the immune cells too [259], and the SCFAs derived from them strengthen gut barrier function, promoting the growth of other beneficial bacteria as well [260].

\subsection{Vitamins}

Studies that focus on malnutrition and gut health have suggested that interactions between microbiota and the proportion of dietary vitamins are significant for immune function [167]. Vitamins are essential components that must be taken from the diet, and are crucial in microbiome dynamics [261]. These substances have multiple targets in endothelial and immune system cells.

Vitamin A (Vit A) and vitamin D (Vit D) play fundamental roles in the effective functioning of the immune system and intestinal homeostasis, modulating microbiota and strengthening barrier function [262]. Both vitamins attach to host receptors and regulate the expression of tight junctions on the intestinal epithelium. While suppressing IFN $\gamma$ and IL-17 signaling from T CD4+ and inducing Treg activity, they contribute to the maintenance of microbial communities [263]. The outcome of a deficiency in these two micronutrients includes Proteobacteria increase and drastic Bacteroidetes reduction, besides the much lower expression of claudins and occludins [264].

Vit A, which is lipid soluble, seems to be the most described vitamin in terms of its pleiotropic immunomodulation effects [265]. It may be found in animal sources, such as beef liver or cheese, and in plant-based foods as provitamin A, in carrots, peppers, pumpkin or spinach, among others. Preclinical insights demonstrate that Vit A deficiency is related to disrupted BA metabolism and the advancement of Bacteroides vulgatus [266]. Moreover, there is a bidirectional effect between gut and microbiota that results in $\operatorname{IgA}$ production. SCFA acetate attaches to the GPR43 receptors on DCs, and thus these cells convert Vit A into retinoic acid (RA) [267]. This could be enhanced by a higher intake of dietary fiber, as this provides a greater amount of SCFA, and furthermore, these metabolites stimulate the activity of the retinal dehydrogenase enzyme in DC [268]. Together with Vit A intake, evidence shows that SCFA aids in preventing food allergies, reducing inflammatory responses to food antigens [269]. Therefore, SCFAs promote RA production by DC, creating an anti-inflammatory environment in the presence of IL-10 and TGF- $\beta$, increasing Treg over Th17. For its part, RA increases the conversion of Treg by inhibiting the secretion of pro-inflammatory cytokines [270,271].

Vit D, which is lipid-soluble, is a promising modulator, associated with a better response to infections, and it is used for autoimmune disease treatment [272]. It is found in few foods, so its deficiency is quite common; it is highly present in fatty fish such as salmon, tuna, mackerel, and fish liver oils, and lower concentrations of the D3 form are found in cheese and egg yolk. Animal models describe that the deficiency of it active form, 1,25(OH)2D3 (D3), reduces defences against infection, and triggers inflammatory mediators response TNF- $\alpha$, IL-1 $\beta$, IL-6, TGF- $\beta$ and IL-17A [273]. The principal mechanism occurs when Vit D meets its receptor (VDR), which is located in B and T cells, lymphocytes, monocytes, macrophages and DC. The interaction between VDR and Vit D directly influences gut microbiota composition. In addition, bacteria metabolites may regulate Vit D and VDR at multiple levels, and orchestrate immune responses, promoting DC activity and Treg maturation, while reducing pro-inflammatory cytokines release [274]. In the same manner, VDR is highly expressed in ileon, and its signaling by Vit D is key to optimal Paneth defensins release. Thus, Vit D plays a prominent role in immune tolerance. HFD together with Vit D deficiency leads to specific defensins production and the inhibition of MUC2, causing lower tight junctions expression and thus higher gut permeability, dysbiosis, endotoxemia, systemic inflammation, fatty liver and insulin resistance [275], and typical disruptions in NAFLD, T2DM, obesity or MetS [276,277].

There are other vitamins with antioxidant potential, including vitamin $C$ (Vit $C$ ), or ascorbic acid, and Vitamin E (Vit E), or $\alpha$-tocopherol. Vit C, which is hydrosoluble (found in citrus fruits, tomatoes, red pepper and brussels sprouts), is a dietary helper for infections, 
as it is well leveraged by phagocytes and T cells [278]. Its best trait is its being an electron donator, behaving as an enzymes regulator. When it is found stored in phagocytes, Vit $C$ activates the enzymes implied in phagocytosis, and enhances microbial killing [279]. Rodent models show how deficiencies in Vit C correlate with increased levels of IL-6; however, this inflammatory response does not seem to implicate gut microbiota [280]. Vit E, which is lipid-soluble (the best sources are nuts, seeds and vegetable oils), gives protection to PUFA integrity in cell membranes [281], protects intestinal mucosa against damage from ROS [282], and avoids the upregulation of cell adhesion molecules (CAMs) such as intercellular adhesion molecule 1 (ICAM1) and vascular cell-adhesion molecule 1 (VCAM1) [283,284]. Although Vit E deficiency is less common, recommendations in terms of supplementation and diet may be aimed at the elderly to boost immune competence [285], thus inhibiting the secretion of pro-inflammatory cytokines, IFN $\gamma$, IL-6 and TNF- $\alpha$. Knowledge related to the gut microbiota is less supported by evidenced; recent studies in animal models suggest that low Vit E consumption alters gut microbiota composition through increasing the Firmicutes:Bacteroidetes ratio, while raising the body weight [286].

It is necessary to mention the interesting B-group vitamins, which are hydrosoluble, and which serve as a source of enzyme cofactors for the host [287]. These cannot be synthesized by mammals, so they ought to be taken from the diet or microbiota, as not all gut bacteria are able to produce them and yet they need them, as does the host [288], that is, there are auxotrophic and prototrophic bacteria. Such is the case with some butyrateproducing species from the Firmicutes phyla that are autotrophic and depend on diet and prototrophic bacteria [289]. Foods that are rich in B-group vitamins include milk, cheese, eggs, liver, meat, tuna and salmon, among others. Scarcity in any of these is related to CVD and cognitive dysfunction in aging [290]; therefore, proposals of their supplementation in the elderly are increasing, especially with folate (vitamin B9), cobalamin (B12), pyridoxine (B6) and riboflavin (B2) [291]. A broad spectrum of properties could be mentioned, and some of these will be illustrated with examples.

Thiamine (B1) (found mainly in whole-grain cereal, fish, red meat, poultry, milk and dairy products) is anti-inflammatory, activates apoptotic proteins and sparks cytochrome $\mathrm{C}$ liberation. Its deficiency is called beriberi, implicating $\mathrm{T}$ cell infiltration and inflammatory status activation with IL-1, TNF and IL-6 release [292].

Riboflavin (B2) (highly present in beef, oats, yogurt, milk and almonds) exhibits antioxidant, anti-aging, anti-inflammatory and anti-cancer features [293]. Some studies show the advantages of its supplementation in terms of disease status, such as for Crohn's, entailing a decrease in Enterobacteriaceae [294] (Julius Z H von Martels et al. 2020), thus ameliorating dysbiosis status.

Niacin (B3) (from beef, poultry, salmon, tuna, pork, rice, peanuts, potato, etc.) has effects on lipid modification [295] that are associated with CVD risk reduction. In addition, in inflammation associated with T2DM and MetS, in which patients have increased adhesion molecules expression, a supply of B3 may help avoid monocytes' adhesion to endothelial cells [296]. Niacin and its derivatives play a role in pro-inflammatory macrophages or M1 maturation, and contribute to polarization towards the anti-inflammatory phenotype M2 [297], a well-valued aspect of neurodegenerative disease treatment research [298] that is associated with gut dysbiosis [299].

Pantothenic acid (B5) (from beef liver, cereals, sunflower seeds, chicken, tuna, avocado, etc.) is able to regulate intestinal immunity, interfering as well with the mRNA of tight junctions, NF-kB and NRF2. An optimal supply provides the strengthening of barrier functions, increasing the expression of claudins and occludins [300]. Research suggests it is an adjuvant of host defines, and that most Bifidobacterium spp. and some Lactobacillus spp. auxotrophic for B5 take it as fuel [288]. A lack of vitamin D can lead also to a lack of pantothenic acid [301].

Pyridoxine (B6) (found in chickpeas, beef liver, tuna, salmon, chicken breast, potatoes, banana, etc.) is a cofactor for several reactions, including inflammatory signaling, such 
as in the kynurenine pathway [302]. This B6 has greater requirements with aging [291], and its reduced concentration contributes to depletions in $\mathrm{T}$ lymphocytes proliferation and differentiation [303]. More recent evidence describes B6's interactions with mitochondrial integrity and inflammasomes [304].

Biotin (B7/B8/H) (highly present in beef liver, cooked egg, salmon and cooked pork chop), is a vitamin that consists of a ligand for several carboxylases involved in gluconeogenesis, fatty acid synthesis and amino acids metabolism. In the event of metabolic function impairment, biotin may not bind to carboxylases, and thus induces inflammation [305]. In the LPS-induced inflammation situation, a deficiency of biotin implies an enhanced secretion of proinflammatory cytokines TNF- $\alpha$, IL-23, IL-1 $\beta$, IFN- $\gamma$ and IL-17 [306], and the greater differentiation of CD4+ T into Th1 and Th17, increasing the inflammation status [307].

Folate (B9) (rich in beef liver, spinach, black-eyed peas, rice, asparagus, lettuce, avocado, etc.) is a powerful methyl group donator, is involved in multiple processes [308], and is immunologically determinant of Treg survival, as these express folate receptor 4 (FR4). Lessening B9 induces Treg apoptosis, provoking higher intestinal inflammation [309]. Interestingly, some animal models have shown an increased Firmicutes:Bacteroidetes ratio associated with folate deficiency [310]. Recent studies have proposed the use of probiotic bacteria to increase folate production, therefore addressing gut dysbiosis associated with folate deficiencies [311].

Cobalamin (B12) is a potent antioxidant (predominantly in meat, fish, milk and eggs). It interferes in oxidative stress scavenging ROS [312]. Surprisingly, differences in gut microbiota have not been found between B12-deficient and non-deficient children [313]; however, it is known that bacteria do not deliver enough B12 to humans, and they compete for its derivatives [314]. Sometimes, the inconvenience of supplementation leads to the proliferation of pathogens that take advantage of B12, which reduces the expression of genes from prototrophic bacteria that synthesize the vitamin [315].

\subsection{Trace Elements}

Other micronutrients are highly present in $\mathrm{MD}$, as are minerals that present multiple benefits for health, gut microbiota and the immune system. For instance, they are relevant in the protection against oxidative damage [316]. The transition metals zinc ( $\mathrm{Zn})$ and iron (Fe) act as cofactors furnishing the redox properties in order to facilitate $T$ cell activation [317].

$\mathrm{Zn}$ represents almost $10 \%$ of the human proteome [318], and may be the trace element with the most robust evidence for immunomodulation [319]. Foods with high contents of this mineral may include cooked oysters, beef, crab, lobster, pork, baked beans, chicken or pumpkin. The Zn signaling pathway leads to the control of immune functions, as it targets a broad spectrum of molecules in the cells triggering proliferation, differentiation, survival and migration [320]. Its deficiencies denote a decreased number of cells of innate and adaptative immunity [321]. In mouse models, feeding with excesses of Zn could cause limitations of inflammatory events in the intestine, although no alteration in fecal microbiota [322]. Studies in humans that concern the supplementation of adjuvants for infection treatment, such as Campylobacter jejuni, are still limited [323]. Further research about microbiota- $\mathrm{Zn}$ interplay is still needed.

On the other hand, Fe aids the growth of commensal, but also pathogenic, bacteria in the intestine, possibly increasing inflammation. Furthermore, under inflammation conditions, as in IBD, iron metabolism is disrupted, causing anemia in the host $[324,325]$. Moreover, Fe deficiency spoils Th1 activity [326]. The side effects of not absorbing the excess of Fe in the intestinal lumen will have consequences for host-healthy microbes interplay [327]. Recent studies have focused on the possibility of reducing the iron availability to gut microbiota in the colon, with the aim of reducing pathogen growth [328]. Furthermore, the Bifidobacteriaceae family has the ability to bind iron in the large intestine, thus attenuating the damage caused by the free radicals produced in iron metabolism [329]. For this reason, and as discussed in the case of polyphenols above, vitamin or mineral 
deficiencies may be benefited from supplementation, not only with these substances but also with probiotics.

Non-metal selenium (Se), which also has redox features, displays immunobiological activity when binding to selenoproteins [330], and has special potential in its resistance to viral infections [326]. Selenoproteins are key in ROS modulation, and influence lymphocyte activation, proliferation and differentiation [331], but not all types of immune responses are well described yet [332]. Some studies have demonstrated that microbial diversity increases in the presence of dietary Se [333]. Further research is still needed to comprehend selenoproteins-microflora interactions.

To sum up, MD counts on a wide variety of nutritional components that are clearly beneficial for the proper functioning of the gut microbiota and immune system, as represented in Table 1 . These effects are prominently contrary to those reported by WD, as will be discussed below.

\section{Western Dietary Pattern as a Model of Unhealthy Eating}

Contrary to the MD, WD represents a global concern, and is responsible for the obesity pandemic and NCDs, including cancer, CVDs, osteoporosis, autoimmune diseases or T2DM, among others [334]. WD are characterized by a high content of unhealthy fats, refined grains, sugar, salt, alcohol and other harmful elements, along with a reduced consumption of fruits and vegetables. This leads to critical changes in both gut microbiota and immune system, negatively affecting the gut integrity, and thus promoting local and systemic chronic inflammation $[335,336]$.

To understand the unfavorable effects of WDs, it is crucial to know the concept "food matrix", which, in a simple manner, states that the different compounds located in the food interact in a coordinated way in the human body, determining the positive or negative effect of an aliment [337]. Thus, although they have similar contents of macronutrients, MD represents a protective factor for obesity and other NCDs, while WD is clearly a risk factor [338]. Ultra-processed food and drinks (UPFDs), designated by the NOVA classification based on the nature, extent and purpose of processing [339], are considered a major hallmark of WDs, and a higher consumption of these components appears to be related with an increased risk of morbidities [340-342] and mortality [343], although further studies are needed to establish causality. UPFDs are highly profitable, hyper-palatable and ready-to consume products, mainly composed of the non-habitual ingredients of "real food" (e.g., hydrogenated/de-esterified oils or additives designed to provide the previous characteristics mentioned) [344]. In addition, the other deleterious elements found in the WD pattern, such as added sugars, carbohydrates and saturated fat, are abundantly found in UPFDs, while beneficial micronutrients, such as previously reported vitamins $\mathrm{A}, \mathrm{C}, \mathrm{D}, \mathrm{E}$ and trace-elements such as zinc, phosphorus, calcium, magnesium or potassium are inversely related with their consumption [345]. UPFDs are equally a worrisome issue for children, who are a vulnerable population, not only as regards their consumption, but also in terms of suffering their negative effects [346,347]. The poor matrix of these foods combined with their reduced fiber contents generates an unfavorable environment in the gut and the microbiome, therefore leading to dysbiosis and immune alterations [348,349]. Thus, proper education, awareness and measures are needed from a public health perspective. Here, we will summarize the evidence regarding the different elements of WD and UPFDs so as to shed light on their relationship with gut microbiota and immune system status. 
Table 1. The role of dietary components abundant in MD in the gut microbiota, immune system, intestinal barrier, and systemically.

\begin{tabular}{|c|c|c|c|c|c|c|c|c|}
\hline Nutrient & Top Food Source & $\begin{array}{l}\text { Recommended } \\
\text { Intakes }\end{array}$ & Immunomodulation & $\begin{array}{l}\text { Gut Microbiota } \\
\text { Modulation }\end{array}$ & $\begin{array}{c}\text { Excess/ } \\
\text { Deficit Effects }\end{array}$ & $\begin{array}{c}\text { Effect on Epithelial } \\
\text { BARRIER }\end{array}$ & $\begin{array}{l}\text { Other Physiological } \\
\text { Effects Affecting } \\
\text { Immunocompetence }\end{array}$ & References \\
\hline MUFAs: oleic acid & $\begin{array}{l}\text { EVOO, olive oil, } \\
\text { olives }\end{array}$ & $\longrightarrow$ & $\begin{array}{c}\downarrow \text { IL-6, IL-17A, } \\
\text { TNF- } \alpha, \text { IL-1 } \beta, \text { COX-2 }\end{array}$ & $\begin{array}{c}\uparrow \text { Bifidobacterium } \\
\text { and Lactobacillus } \\
\text { } \begin{array}{c}\uparrow \text { Butyrate } \\
\text { production }\end{array}\end{array}$ & $\begin{array}{c}\text { Excess: } \\
\downarrow \text { number of total } \\
\text { bacteria }\end{array}$ & $\begin{array}{l}\text { Keeping } \\
\text { integrity }\end{array}$ & $\begin{array}{l}\downarrow \text { LDL-c, LDL-c oxidized } \\
\text { and blood pressure. } \\
\\
\text { Anti-inflammatory, } \\
\text { atheroprotective, } \\
\text { colonocytes protection } \\
\text { against oxidative stress }\end{array}$ & [194-203] \\
\hline$\omega-3$ & $\begin{array}{l}\text { Fish, seafood, nuts, } \\
\text { seeds, plant oils, } \\
\text { eggs, dairy products }\end{array}$ & $\begin{array}{c}1.6 \mathrm{~g} \text { (male) } \\
1.1 \mathrm{~g} \text { (female) }\end{array}$ & $\begin{array}{c}\text { CLA: } \\
\uparrow \text { Treg production } \\
\uparrow \text { NF- } \alpha \text {, IL-1 } 1 \beta \text {, and } \\
\text { IL-6 } \\
\downarrow \text { IL-10 and PPAR- } \gamma\end{array}$ & $\begin{array}{c}\text { Balance Firmi- } \\
\text { cutes:Bacteroidetes } \\
\text { ratio } \\
\downarrow \text { LPS-producing } \\
\text { Enterobacteria } \\
\text { Can produce CLA } \\
\text { and CLnA: } \\
\uparrow \begin{array}{c}\text { Ruminococcus and } \\
\text { Prevotella }\end{array}\end{array}$ & & & & $\begin{array}{c}{[206]} \\
{[211-216]}\end{array}$ \\
\hline$\omega-6$ & $\begin{array}{c}\text { Vegetable oils, nuts, } \\
\text { seed, soy derivates } \\
\text { like tofu, eggs or } \\
\text { poultry }\end{array}$ & & $\begin{array}{l}\text { ARA is a precursor } \\
\text { of pro-inflammatory } \\
\text { molecules: } \\
\text { eicosanoid hormones } \\
\text { prostaglandins or } \\
\text { leukotrienes }\end{array}$ & & & & & {$[207,208]$} \\
\hline $\begin{array}{l}\text { Polyphenols } \\
\text { (flavonoids and } \\
\text { non-flavonoids) }\end{array}$ & $\begin{array}{l}\text { Berries anthocyanins, } \\
\text { olives, nuts tannins } \\
\text { aromatic plants and } \\
\text { spices (dried herbs } \\
\text { like oregano, } \\
\text { rosemary, thyme, } \\
\text { etc.), seeds (cumin, } \\
\text { sesame, etc.) }\end{array}$ & - & $\begin{array}{l}\downarrow \text { Pro-inflammatory } \\
\text { molecules }\end{array}$ & $\begin{array}{c}\text { Prebiotic effect: } \\
\uparrow \text { Lactobacillus spp. } \\
\downarrow \text { Enterococcus } \\
\text { caccae } \\
\downarrow \text { Dysbiosis } \\
\uparrow \text { Microbial } \\
\text { diversity }\end{array}$ & & $\begin{array}{c}\text { Keeping } \\
\text { semipermeable } \\
\text { character: some } \\
\uparrow \text { tightjunctions and } \\
\text { some } \downarrow\end{array}$ & $\begin{array}{l}\text { Antioxidant and } \\
\text { anti-inflammatory }\end{array}$ & [217-222] \\
\hline
\end{tabular}


Table 1. Cont.

\begin{tabular}{|c|c|c|c|c|c|c|c|c|}
\hline Nutrient & Top Food Source & $\begin{array}{l}\text { Recommended } \\
\text { Intakes }\end{array}$ & Immunomodulation & $\begin{array}{l}\text { Gut Microbiota } \\
\text { Modulation }\end{array}$ & $\begin{array}{c}\text { Excess/ } \\
\text { Deficit Effects }\end{array}$ & $\begin{array}{l}\text { Effect on Epithelial } \\
\text { BARRIER }\end{array}$ & $\begin{array}{l}\text { Other Physiological } \\
\text { Effects Affecting } \\
\text { Immunocompetence }\end{array}$ & References \\
\hline HT & EVOO & - & $\begin{array}{l}\text { Inhibits TLR-4 and } \\
\text { NF-kB } \\
\downarrow \text { TNF- } \alpha \text {, IL-1 } \beta \text {, IL-6 } \\
\text { in inflammation } \\
\text { status }\end{array}$ & $\uparrow$ Bifidobacterium & & Keeping integrity & $\begin{array}{c}\text { Anti-inflammatory, } \\
\text { antioxidant, } \\
\text { cardio-protection, } \\
\downarrow \text { ox-LDL, TG, oxidative } \\
\text { stress }\end{array}$ & [224-227] \\
\hline RSV & Red grapes & - & $\begin{array}{c}\text { Inhibit NF-kB } \\
\text { Block TLR4 } \\
\downarrow \text { Th17, IL-17, } \\
\text { eicosanoids }\end{array}$ & $\begin{array}{c}\downarrow \text { Firmicutes: } \\
\text { Bacteroidetes } \\
\downarrow \text { Enterococcus faecalis } \\
\uparrow \text { Lactobacillus } \\
\text { and } \\
\text { Bifidobacterium }\end{array}$ & & Keeping integrity & $\begin{array}{c}\text { Antioxidant, } \\
\text { anti-inflammatory } \\
\downarrow \text { oxidative stress } \\
(+) \text { NRF2: anti-aging }\end{array}$ & [228-232] \\
\hline QUE & $\begin{array}{l}\text { Onions, broccoli, } \\
\text { apple, citrus fruits } \\
\text { and vegetables }\end{array}$ & - & $\begin{array}{c}\downarrow \text { LPS, NO, PGE } \\
\text { iNOS, COX-2, } \\
\text { TNF- } \alpha, \text { IL-1 } \beta, \text { IL-6 } \\
\downarrow \text { Th1 } \\
\text { Modulation } \\
\text { Th1/Th2 balance }\end{array}$ & $\begin{array}{c}\text { Bacteroides, } \\
\text { Bifidobacterium, } \\
\text { Lactobacillus, and } \\
\text { Clostridia } \\
\text { against reduction of } \\
\text { Enterococcus }\end{array}$ & & Keeping integrity & $\begin{array}{l}\text { Anti-allergic potential, } \\
\text { anti-inflammation }\end{array}$ & [233-238] \\
\hline $\begin{array}{c}\text { Soluble: } \\
\text { } \text {-Glucans } \\
\text { Oligosaccharides } \\
\text { (inulin, OF, lactulose, } \\
\text { FOS, GOS, dextrin) }\end{array}$ & $\begin{array}{l}\text { Fruit } \\
\text { Oat grain, barley, } \\
\text { wheat }\end{array}$ & & $\begin{array}{c}\text { DC maturation } \\
(+) \text { B and T cells } \\
\downarrow \text { LPS, TNF- } \alpha\end{array}$ & $=$ & $\begin{array}{c}\text { Only FOS and GOS } \\
\text { supplementation } \\
\downarrow \text { Some } \\
\text { butyrate-producing } \\
\text { bacteria } \\
\text { (e.g., } \text { Ruminococcus } \\
\text { sp) }\end{array}$ & Strengthening & $\begin{array}{c}\uparrow \text { Satiety sensation } \\
\text { Antioxidant: } \\
\downarrow \text { Oxidative stress } \\
\downarrow \text { c-LDL }\end{array}$ & $\begin{array}{c}{[245]} \\
{[250-256]}\end{array}$ \\
\hline Insoluble: & Cereal & & $=$ & $\begin{array}{c}= \\
\uparrow \text { Colonic } \\
\text { fermentation }\end{array}$ & Excess is laxative & Strengthening & $\begin{array}{c}\text { Glucose tolerance } \\
\text { Anti-inflammatory } \\
\downarrow \downarrow \text { T2DM risk }\end{array}$ & $\begin{array}{l}{[246,247]} \\
{[257-260]}\end{array}$ \\
\hline Vitamins & & & Pleiotropic & & & & Pleiotropic & $\begin{array}{c}{[187,188]} \\
{[261]}\end{array}$ \\
\hline
\end{tabular}


Table 1. Cont.

\begin{tabular}{|c|c|c|c|c|c|c|c|c|}
\hline Nutrient & Top Food Source & $\begin{array}{l}\text { Recommended } \\
\text { Intakes }\end{array}$ & Immunomodulation & $\begin{array}{l}\text { Gut Microbiota } \\
\text { Modulation }\end{array}$ & $\begin{array}{c}\text { Excess/ } \\
\text { Deficit Effects }\end{array}$ & $\begin{array}{c}\text { Effect on Epithelial } \\
\text { BARRIER }\end{array}$ & $\begin{array}{l}\text { Other Physiological } \\
\text { Effects Affecting } \\
\text { Immunocompetence }\end{array}$ & References \\
\hline Vitamin A & $\begin{array}{c}\text { Animal sources like } \\
\text { beef liver or cheese, } \\
\text { and in plant-based } \\
\text { foods as provitamin } \\
\text { A, in carrots, } \\
\text { peppers, pumpkin, } \\
\text { spinach }\end{array}$ & $\begin{array}{l}900 \mu \mathrm{g} \\
\text { (Including } \\
\text { pro-vitamin A } \\
\text { carotenoids) }\end{array}$ & $\begin{array}{c}\downarrow \text { IFN } \gamma \text { and IL-17 } \\
\qquad \uparrow \text { Treg }\end{array}$ & $\begin{array}{c}\text { Maintain diversity } \\
\downarrow \text { Firmi- } \\
\text { cutes:Proteobacteria } \\
\text { ratio }\end{array}$ & $\begin{array}{c}\text { Deficiency -> } \\
\text { Disrupted BA } \\
\text { metabolism } \\
\uparrow \text { Bacteroides vulgatus } \\
\text { and } \downarrow \text { tight junctions } \\
\text { (claudins and } \\
\text { occludins) }\end{array}$ & $\begin{array}{l}\text { Strengthening: } \\
\uparrow \text { tight junctions }\end{array}$ & $\begin{array}{l}\text { Anti-inflammatory } \\
\text { Allergy prevention }\end{array}$ & [262-270] \\
\hline \multirow[t]{3}{*}{ Vitamin D } & \multirow[t]{3}{*}{$\begin{array}{l}\text { Highly in fatty fish } \\
\text { like salmon, tuna, } \\
\text { mackerel, and fish } \\
\text { liver oils; lower } \\
\text { concentrations of D3 } \\
\text { form are found in } \\
\text { cheese and egg yolk }\end{array}$} & \multirow[t]{2}{*}{$15 \mu \mathrm{g}$} & $\begin{array}{c}\downarrow \text { IFN } \gamma \text { and IL-17 } \\
\uparrow \text { Treg } \\
\text { (+) VDR: Treg } \\
\text { maturation } \\
\downarrow \begin{array}{c}\text { Pro-inflammatory } \\
\text { cytokines }\end{array}\end{array}$ & $\begin{array}{c}\text { Maintain diversity: } \\
\downarrow \text { Firmicutes: } \\
\text { Proteobacteria } \\
\text { ratio }\end{array}$ & $\begin{array}{c}\downarrow \text { MUC2 } \\
\downarrow \text { Tight junctions } \\
\text { (Claudins and } \\
\text { occludins) } \\
\text { Dysbiosis } \\
\text { Endotoxemia } \\
\text { Bad response against } \\
\text { infections ( } \uparrow \text { TNF- } \alpha \text {, } \\
\text { IL-1 } \beta, \text { IL-6, TGF- } \beta \text {, } \\
\text { IL-17A) }\end{array}$ & \multirow[t]{3}{*}{$\begin{array}{l}\text { Strengthening: } \\
\uparrow \text { Tight junctions } \\
\text { Optimal Paneth } \\
\text { defensins release }\end{array}$} & & \multirow[t]{3}{*}{$\begin{array}{l}{[262-264]} \\
{[272-277]}\end{array}$} \\
\hline & & & $\uparrow$ Tolerance & & $\begin{array}{c}\text { Fatty liver } \\
\text { Insulin resistance }\end{array}$ & & & \\
\hline & & & & & $\downarrow$ B5 & & & \\
\hline Vitamin C & $\begin{array}{l}\text { Citrus fruits, } \\
\text { tomatoes, red pepper } \\
\text { and brussels sprouts }\end{array}$ & $\begin{array}{c}90 \mathrm{mg} \text { (male) } \\
75 \mathrm{mg} \text { (female) }\end{array}$ & $\begin{array}{l}\text { Helps } \mathrm{T} \text { and } \\
\text { phagocytes in } \\
\text { infections }\end{array}$ & $\begin{array}{l}\uparrow \text { Killing of } \\
\text { pathogens }\end{array}$ & $\begin{array}{l}\text { Deficiencies } \\
\uparrow \text { IL-6 }\end{array}$ & Keeping integrity & Antioxidant & [278-280] \\
\hline & & & & & Deficiency in elderly & & $\begin{array}{l}\text { Antioxidant } \\
\text { Protects PUFAs } \\
\text { in cell }\end{array}$ & \\
\hline Vitamin E & $\begin{array}{l}\text { Nuts, seeds and } \\
\text { vegetable oils }\end{array}$ & $15 \mathrm{mg}$ & $\downarrow$ IFN $\gamma$, IL-6, TNF- $\alpha$ & & $\begin{array}{c}\text { Excess } \\
\uparrow \text { Fermi- } \\
\text { cutes:Bacteroidetes }\end{array}$ & $\begin{array}{c}\text { Protects barrier from } \\
\text { ROS }\end{array}$ & $\begin{array}{c}\text { membranes } \\
\downarrow \text { CAMs } \\
\text { Anti-aging }\end{array}$ & [281-285] \\
\hline
\end{tabular}


Table 1. Cont.

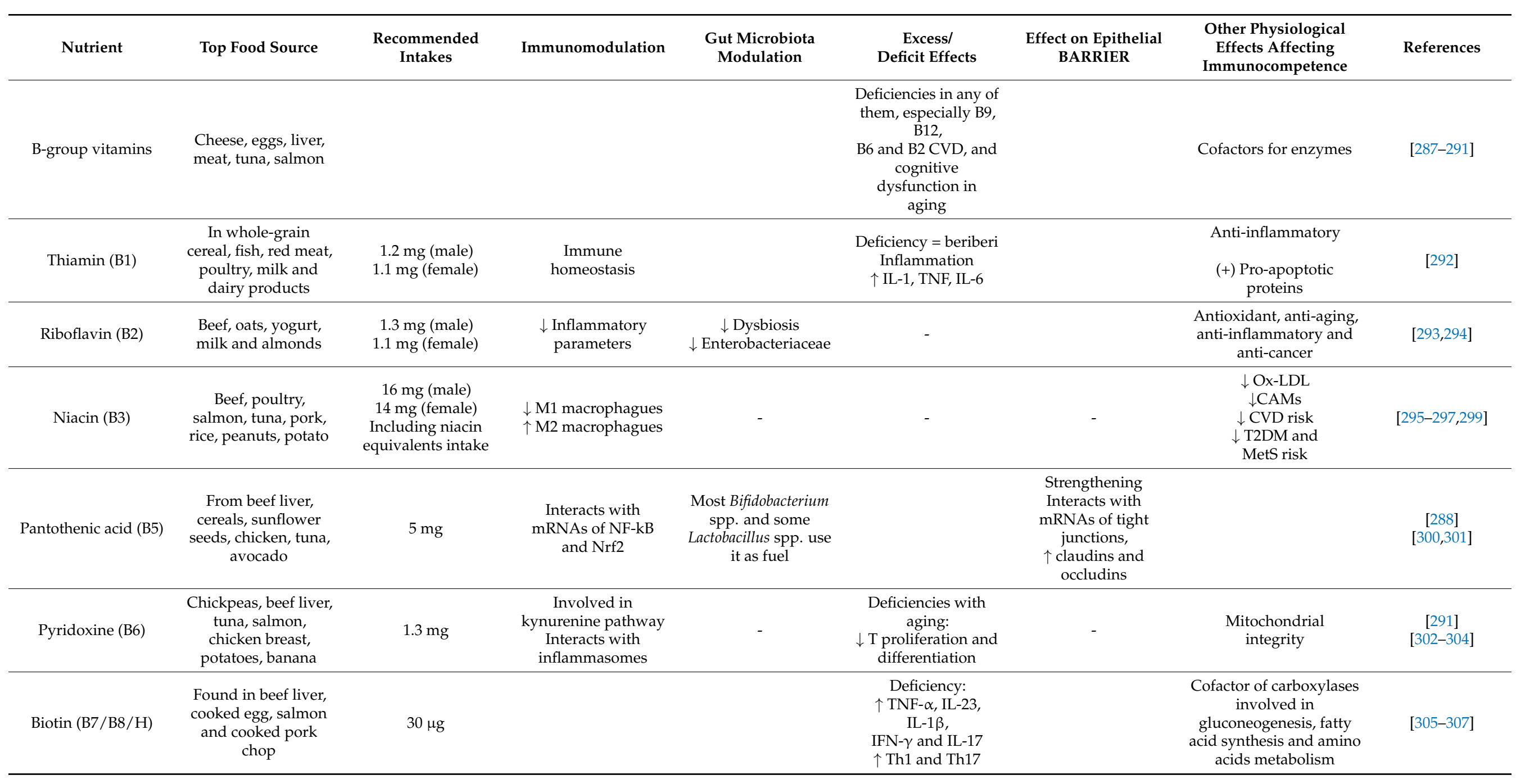


Table 1. Cont.

\begin{tabular}{|c|c|c|c|c|c|c|c|c|}
\hline Nutrient & Top Food Source & $\begin{array}{l}\text { Recommended } \\
\text { Intakes }\end{array}$ & Immunomodulation & $\begin{array}{l}\text { Gut Microbiota } \\
\text { Modulation }\end{array}$ & $\begin{array}{c}\text { Excess/ } \\
\text { Deficit Effects }\end{array}$ & $\begin{array}{l}\text { Effect on Epithelial } \\
\text { BARRIER }\end{array}$ & $\begin{array}{l}\text { Other Physiological } \\
\text { Effects Affecting } \\
\text { Immunocompetence }\end{array}$ & References \\
\hline Folate (B9) & $\begin{array}{l}\text { Beef liver, spinach, } \\
\text { black-eyed peas, rice, } \\
\text { asparagus, lettuce, } \\
\text { avocado }\end{array}$ & $400 \mu \mathrm{g}$ & Treg survival & & $\begin{array}{l}\text { Deficiency: Treg } \\
\text { apoptosis } \\
\uparrow \text { Intestinal } \\
\text { inflammation } \\
\text { Dysbiosis }\end{array}$ & & $\begin{array}{l}\text { Methyl groups donator } \\
\text { so important in } \\
\text { epigenetics }\end{array}$ & {$[308,309]$} \\
\hline Cobalamin (B12) & $\begin{array}{l}\text { Meat, fish, milk and } \\
\text { eggs }\end{array}$ & $2.4 \mu \mathrm{g}$ & & & $\begin{array}{l}\text { Excess } \\
\uparrow \text { pathogens } \\
\text { proliferation }\end{array}$ & & $\downarrow$ ROS & [312-315] \\
\hline Trace elements & & & $\begin{array}{l}\text { Cofactors with redox } \\
\text { properties that } \\
\text { facilitate } T \text { cell } \\
\text { activation }\end{array}$ & & & & $\begin{array}{l}\text { Protection against } \\
\text { oxidative stress }\end{array}$ & {$[316,317]$} \\
\hline $\mathrm{Zn}$ & $\begin{array}{l}\text { Cooked oysters, beef, } \\
\text { crab, lobster, pork, } \\
\text { baked beans, chicken } \\
\text { or pumpkin }\end{array}$ & $\begin{array}{l}11 \mathrm{mg} \text { (male) } \\
8 \mathrm{mg} \text { (female) }\end{array}$ & $\begin{array}{l}\text { Modulates NF-kB } \\
\text { pathway, controls } \\
\text { oxidative stress and } \\
\text { is implicated in } \\
\text { anti-inflammatory } \\
\text { and } \\
\text { pro-inflammatory } \\
\text { responses }\end{array}$ & - & $\begin{array}{c}\text { Deficiencies } \\
\downarrow \text { number of immune } \\
\text { cells }\end{array}$ & - & $\begin{array}{l}\text { Involved in multiple cell } \\
\text { events: proliferation, } \\
\text { differentiation, survival } \\
\text { and migration }\end{array}$ & [318-323] \\
\hline $\mathrm{Fe}$ & $\begin{array}{l}\text { Meat, seafood, nuts } \\
\text { and beans }\end{array}$ & $\begin{array}{c}8 \mathrm{mg} \text { (male) } \\
18 \mathrm{mg} \text { (female) }\end{array}$ & & $\begin{array}{c}\text { Bifidobacteriaceae } \\
\text { family helps binding } \\
\text { iron } \\
\downarrow \text { Damage from free } \\
\text { radicals }\end{array}$ & $\begin{array}{c}\text { Abundancy in } \\
\text { intestine, causes } \\
\text { pathogenic bacteria } \\
\text { to proliferate, } \\
\text { causing } \\
\text { anemia in host } \\
\\
\uparrow \text { Inflammation } \\
\text { Deficiency disrupts } \\
\text { Th1 } \\
\text { activity }\end{array}$ & - & - & {$[324,325,329]$} \\
\hline
\end{tabular}


Table 1. Cont.

\begin{tabular}{|c|c|c|c|c|c|c|c|c|}
\hline Nutrient & Top Food Source & $\begin{array}{l}\text { Recommended } \\
\text { Intakes }\end{array}$ & Immunomodulation & $\begin{array}{l}\text { Gut Microbiota } \\
\text { Modulation }\end{array}$ & $\begin{array}{c}\text { Excess/ } \\
\text { Deficit Effects }\end{array}$ & $\begin{array}{c}\text { Effect on Epithelial } \\
\text { BARRIER }\end{array}$ & $\begin{array}{l}\text { Other Physiological } \\
\text { Effects Affecting } \\
\text { Immunocompetence }\end{array}$ & References \\
\hline Se & Seafood and meat & $55 \mu \mathrm{g}$ & $\begin{array}{l}\text { Binds to } \\
\text { selenoproteins and } \\
\text { has potential in } \\
\text { resistance to viral } \\
\text { infections } \\
\\
\text { Influence } \\
\text { lymphocyte } \\
\text { activation, } \\
\text { proliferation and } \\
\text { differentiation }\end{array}$ & $\begin{array}{c}\text { Seems dietary Se } \\
\uparrow \text { microbial diversity }\end{array}$ & & & $\begin{array}{l}\text { Redox reactions: } \\
\text { Selenoproteins play a } \\
\text { role } \\
\text { in ROS modulation }\end{array}$ & {$[326,330-333]$} \\
\hline
\end{tabular}

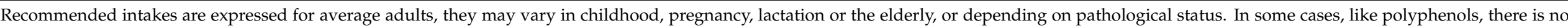

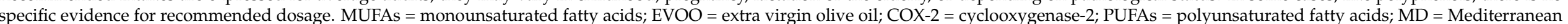

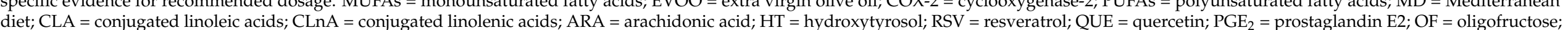
FOS = fructo-oligosaccharides; GOS = galacto-oligosaccharides. 


\subsection{Refined Carbohydrates}

When analyzing unhealthy elements of WDs and UPFDs, refined carbohydrates, particularly added sugar and processed grains (such as white flour or white bread) are elements of note in the negative modulation of the gut microbiota and immune system. Added sugars are all those sugars that are present in foods, mainly UPFDs, or are naturally present in unsweetened fruit juices, honey and syrups [350]. Added sugars are considered empty calories, as they may substitute the intake of components with higher nutritional interest, and their consumption is prominently associated with negative cognitive functioning and addiction [351,352]. Fructose overconsumption, prominently through excessive refined sugars intake, is associated with a systemic pro-inflammatory status, and is also related with cortisol hyperactivation, increased visceral adiposity, and insulin resistance [353]. In addition, the deleterious effects of the consumption of added sugars, and particularly from sugar-sweetened drinks, have been reported in the gut microbiota, promoting an increased Firmicutes/Bacteroidetes ratio and reducing the proportion of favorable butyrate-producers such as Lachnobacterium [354]. Likewise, added sugars provoke augmented gut permeability and endotoxemia, thereby leading to inflammation and systemic complications [355]. Finally, there are inconsistent data when analyzing the consumption of refined versus whole-grain food. Thus, some studies have reported the favorable results obtained from whole-grains consumption in both gut microbiota and the immune system [356], although other research has found a positive effect on inflammation in a gut microbiota-independent manner [357]. Nonetheless, further research is needed to better understand the role of refined grains in human health and pathology [358].

\subsection{Unhealthy Fats}

High-fat diets (HFD) typical of western dietary patterns are equally one of the main concerns of unhealthy eating. In a murine model of C57BL/6 mice fed with a highfat diet (HFD), the microbial composition was different to that of other mice fed with low-fat diets (LFD). HFD mice showed quite elevated Firmicutes:Bacteroidetes ratios, minor antimicrobial Paneth activity, and higher pro-inflammatory IFN $\gamma, \operatorname{TNF} \alpha$, IL-1 $\beta$ and IL-6 cytokines concentrations [359], along with bacterial translocation leading to endotoxemia [360]

Contrary to classical beliefs, saturated fats are not the main enemy of a healthy diet. In fact, they could be included as part of one [361]. On the other hand, trans fats are mostly considered a negative or harmful fat, as they are frequently present in UPFDs [362], although they could be found naturally in ruminants-derived products, acting as a precursor of linoleic acid, a beneficial lipid [363], showing again that the method of processing and the food matrix, rather than the nutrients, provide the benefits or dangers derived from food consumption. Trans fatty acids intake in the context of WD has been reported as a potential cause of gut dysbiosis [364]. As such, unhealthy fats have been related to gut dysfunction, including the disruption of enteroendocrine cells [365] and the promotion of intestinal permeability and inflammation, mainly affecting critical gut microbiota populations and LPS [182]. The established endotoxemia could be directly associated with low-grade chronic inflammation, thus conducting to the development of NCDs [366]. Microbial regulators of BA are also potentially affected by unhealthy fats, which may aid in the establishment of certain conditions, such as obesity [367].

WD and UPFDs are both frequently rich in refined oils, which may have profound impacts not only from a health perspective, but also in terms of sustainability [368]. A classic example is palm oil (PO), the most exploited oil worldwide, which represents a threat to ecological sustainability due to the combination of UPFD and unhealthy products contributing to a higher risk of NCDs [369]. Contrary to non-refined PO, which is composed of saturated fats (mainly palmitic acid) but also contains many antioxidants (essentially tocotrienols and tocophenols), refined PO presents quite a reduced content of these antioxidants, and therefore the quality of the oil is reduced too [370]. In this sense, refined $\mathrm{PO}$ seems to have powerful negative effects on the gut microbiota, decreasing the 
abundance of Akkermansia muciniphila, SFB, and Clostridium leptum, leading to the release of pro-inflammatory cytokines and the loss of intestinal integrity [371]. Refined olive oil, contrary to non-refined EVOO, is associated with a growth of non-beneficial bacteria from the Desulfovibrionaceae, Spiroplasmataceae, and Helicobacteraceae families, along with a reduction in favorable Erysipelotrichaceae and Sutterellaceae, with negative implications for the host's immune system [372]. In the same line, Rodríguez-García et al. [373] showed in animal models that sunflower oil induced Sphingomonas and Neisseria spp., while limiting the growth of Akkermansia muciniphilla and Bifidobacterium. In the same way, coconut oil restricts Akkermansia muciniphilla abundance, while enhancing Staphylococcus, Prevotella and Bacteroides spp. Interestingly, both microbial changes were associated with a pro-inflammatory status, increasing the risk of colorectal cancer.

Furthermore, increased omega- 6 fatty acid levels are typically associated with WDs, particularly due to refined oils and UPFD, increasing the omega 6:omega 3 ratio up to 15:1 [374] and enhancing metabolic endotoxemia through direct interactions with gut microbiota [375]. In this sense, the altered omega 6:omega 3 ratio has been found to promote the development of Enterobacteriaceae, segmented filamentous bacteria and Clostridia spp., leading to a pro-inflammatory environment that could be attenuated by the introduction of omega 3 PUFA [376]. In the same manner, WD is associated with a reduced production of PUFA metabolites, probably through the detrimental effects of this diet on the microbiota [212].

\subsection{Excessive Meat Consumption and Fast Food}

Red meat, and prominently processed meats, are similarly associated with WD patterns. There are many mechanisms that have been proposed in the relationship between processed and red meats and certain pathological conditions, especially as concerns colorectal cancer (CRC) risk, some of which involve the gut microbiota [377]. Among them, red and processed meats contain high levels of L-carnitine, which, along with choline, betaine and lecithin, are considered the precursors of a critical product known as trimethylamine (TMA) by the gut microbiota [378]. Then, TMA is transported to the liver, where it is transformed to trimethylamine $\mathrm{N}$-oxide (TMAO), which is associated with inflammatory pathways and CVD risk [379]. Although TMAO itself might not be considered a negative metabolite, a higher amount of this component is associated with unfavourable outcomes in a context of unhealthy dietary patterns, as TMA is mostly synthesized by Firmicutes and Proteobacteria, two phyla increased with gut dysbiosis [380]. On the other hand, betaine is prominently found in some healthy plant-based components such as spinach and beets, and choline may be found in positive animal-based products like eggs, milk and fish [381]. Interestingly, fish and seafood may also contain TMA and TMAO, having been proved to have conversely anti-inflammatory properties in some studies [382]. These findings show that gut dysbiosis promoted by diet may collaborate with higher levels of TMA and TMAO, leading to pro-inflammatory conditions, but when TMA is not produced by an altered gut microbiota, it may present anti-inflammatory properties, thus demonstrating the direct influence of gut microbiota over immune system status.

Nonetheless, red and processed meats contain elevated levels of negative components, such as heme iron, which has been correlated with an hyperproliferation of colonic enterocytes and the alteration of the intestinal barrier [383]. In particular, changes in $\mathrm{Fu}$ sobacterium nucleatum, Streptococcus bovis/gallolyticus, Escherichia coli, and Bacteroides fragilis have been reported due to excessive red meat consumption, interacting with the other negative factors contained in red meats, including proper heme, $\mathrm{N}$-nitroso compounds and heterocyclic amines [384]. Another key element contained in red and processed meats, $\mathrm{N}$-glycolylneuraminic acid (Neu5Gc), could also be regulated by specific gut microbiota bacteria, thereby increasing or reducing the pro-inflammatory effects of this substance, known as xenosialitis [385].

Fast food is another key element in the western dietary pattern, and it should be addressed not only from a biological perspective, but also from socioeconomic and psy- 
chological approaches [386]. When comparing Mediterranean vs. fast food diets, even over a short time (4 days), critical changes in the gut microbiota have been noted. In particular, there was an augmentation in BA-tolerant bacteria, along with a decrease in SCFA and indole derivate producers [387]. The excessive BA caused by western dietary patterns may be associated with a disruption in the intestinal barrier, therefore promoting a pro-inflammatory environment [388], and under inflammatory and dysbiosis conditions, tryptophan is transformed, via the enzyme indoleamine 2,3-dioxygenase-1 (IDO-1), to kynurenine by the host cells. As such, the reduced levels of tryptophan are related to a reduction in the levels of IL-22, leading to increased intestinal permeability and LPS translocation [389]. This is added to the reduced production of SCFAs, which together show the negative role of fast food and WDs in the gut microbiota and immune system.

\subsection{Salt and Additives.}

Although the recommended values of salt are established at $5 \mathrm{~g} /$ day, the available evidence has demonstrated that a reduced intake of salt should be recommended in the context of health [390]. In this context, different studies have implicated UPFD in the overconsumption of salt, contributing to the appearance of hypertension and CVD [391]. In this sense, Wilck et al. [392] have proven the direct effects of high salt levels in the gut microbiotaTh17 axis, particularly in reducing the populations of Lactobacillus sp., which could be associated with the altered production of SCFA identified in high-salt diets [393,394]. Other populations negatively affected include Oscillibacter, Pseudoflavonifractor, Clostridium XIVa Johnsonella and Rothia, while other species are increased, including Parasutterella spp. Erwinia genus, Christensenellaceae, Corynebacteriaceae Lachnospiraceae and Ruminococcus [395], which could aid in explaining the unfavorable effects of high-salt diets on the organism

Additives are another crucial element of western dietary patterns and UPFD. Despite the fact that some additives could be considered innocuous, an increased amount of studies have identified the negative effects of food additives on gut homeostasis [396]. The most studied food additives are artificial sweeteners and sugar alcohols. Low/non-caloric sweeteners, such as sucralose, are associated even at low doses with gut permeability, inflammation and gut microbiota changes, promoting reductions in beneficial bacteria (Lactobacillus and Bifidobacteria) along with an increase in pathogenic bacteria (Enterobacteria) [397]. Further research is needed to understand how other artificial sweeteners interact with the gut microbiota and immune system, although observational studies seem to indicate similar negative results, particularly for acesulfame K and aspartame [398-400]. Sugar alcohols (e.g., maltitol, xylitol, sorbitol, erythritol) appear to act favorably on gut microbiota composition, acting similarly to prebiotic compounds. The roles of the rest of the additives in terms of gut microbiota and immune system remain to be fully elucidated [401].

Here, we show the main impacts of WD on gut microbiota and the immune system, as summarized in Table 2. Overall, these nutritional components are doubly hazardous: On the one hand, they lead to unfavorable changes in the organism, replacing healthy nutrients such as those contained in MD. On the other hand, these nutrients are contained in a poorer food matrix, with synergic harmful effects explaining the negative interplay between WD, gut microbiota and immune system. 
Table 2. The role of dietary components abundant in WD in the gut microbiota, immune system, intestinal barrier, and systemically.

\begin{tabular}{|c|c|c|c|c|c|c|c|}
\hline $\begin{array}{l}\text { Nutritional } \\
\text { Component }\end{array}$ & Top Food Sources & $\begin{array}{l}\text { Maximum Intake } \\
\text { Limits Per Day/Week }\end{array}$ & Immunomodulation & $\begin{array}{l}\text { Gut Microbiota } \\
\text { Modulation }\end{array}$ & $\begin{array}{c}\text { Intestinal Barrier Damage } \\
\text { and Other } \\
\text { Pathological Effects }\end{array}$ & $\begin{array}{c}\text { Alternatives/Substitutes and } \\
\text { Suggestions }\end{array}$ & Ref \\
\hline $\begin{array}{l}\text { Added /Free } \\
\text { sugars }\end{array}$ & $\begin{array}{l}\text { UPFDs or naturally } \\
\text { present in unsweetened } \\
\text { fruit juices, honey and } \\
\text { syrups }\end{array}$ & $\begin{array}{l}<25 \mathrm{~g} \\
(\downarrow 10 \% \text { of total daily } \\
\text { Caloric intake) }\end{array}$ & $\begin{array}{l}\text { Pro-inflammatory } \\
\text { environment }\end{array}$ & $\begin{array}{c}\uparrow \text { Firmi- } \\
\text { cutes/Bacteroidetes } \\
\text { ratio, } \\
\downarrow \text { population of } \\
\text { favorable butyrate } \\
\text { producers (e.g., } \\
\text { Lachnobacterium sp.) }\end{array}$ & $\begin{array}{l}\text { Intestinal barrier disruption, } \\
\text { endotoxemia, insulin } \\
\text { resistance, visceral adiposity, } \\
\text { cognitive dysfunction and } \\
\text { addiction }\end{array}$ & $\begin{array}{l}\text { Replacing added sugars } \\
\text { consumption by intrinsic } \\
\text { sugars (Whole fruits and } \\
\text { vegetables) } \\
\text { Using healthy sweeteners: } \\
\text { Cinamon, vanilla, dates, } \\
\text { raisins, banana, pumpkin, } \\
\text { sweet potato, etc. }\end{array}$ & [350-355] \\
\hline Refined grains & $\begin{array}{l}\text { White bread, UPFDs, } \\
\text { white flours and } \\
\text { derivates }\end{array}$ & - & $\begin{array}{l}\uparrow \text { IL-6 and CRP levels; } \\
\text { negative functioning in } \\
\text { memory T cells }\end{array}$ & $\begin{array}{c}\text { Probable effects } \\
\uparrow \text { Enterobacteriaceae } \\
\text { while } \downarrow \text { SCFA producers } \\
\text { (Lachnospira) }\end{array}$ & $\begin{array}{l}\text { Further evidence is needed } \\
\text { to determine the possible } \\
\text { effects of refined grains on } \\
\text { the human body }\end{array}$ & $\begin{array}{l}\text { Substituting refined with } \\
\text { whole-grain products. } \\
\text { Combining refined grains } \\
\text { products consumption with } \\
\text { fiber-rich vegetables and fruits } \\
\text { may reduce their detrimental } \\
\text { effects }\end{array}$ & [356-358] \\
\hline Unhealthy fats & $\begin{array}{l}\text { UPFDs, animal } \\
\text { products, fast food }\end{array}$ & $\begin{array}{l}\text { Daily fat } \\
\text { recommendations is } \leq \\
30 \% \text { of total Caloric } \\
\text { intake }\end{array}$ & $\begin{array}{l}\uparrow \text { pro-inflammatory } \\
\text { cytokines IFN } \gamma, \text { TNF } \alpha, \\
\text { IL-1 } \beta \text { and IL-6 }\end{array}$ & $\begin{array}{l}\uparrow \text { Firmicutes/Bacteroidetes } \\
\text { ratio }\end{array}$ & $\begin{array}{c}\downarrow \text { Antimicrobial Paneth cells } \\
\text { activity }\end{array}$ & $\begin{array}{c}\text { Limiting the consumption of } \\
\text { these fats by previous } \\
\text { reported healthy fats (MUFAs, } \\
\text { PUFAs) should be the basis of } \\
\text { fat intake }\end{array}$ & {$[359,360]$} \\
\hline Saturated fats & $\begin{array}{c}\text { Animal-derived } \\
\text { products (Milk, butter, } \\
\text { meat, etc.) and } \\
\text { plant-based foods } \\
\text { (chocolate, nuts, cocoa, } \\
\text { coconut and palm oils) }\end{array}$ & $\begin{array}{l}\text { Not superior to } 10 \% \text { of } \\
\text { daily intake }\end{array}$ & & - & - & $\begin{array}{l}\text { Saturated fats are not as } \\
\text { dangerous as thought before. } \\
\text { It is more important to } \\
\text { observe the quality and } \\
\text { processing of the food, even if } \\
\text { it presents a high content of } \\
\text { saturated fats (e.g., high \% } \\
\text { dark chocholate, nuts or milk) }\end{array}$ & [361] \\
\hline$\omega-6 / \omega-3$ ratio & Previously reported & $\begin{array}{l}\omega-6 / \omega-3 \text { ratio must not } \\
\text { exceed } 4 / 1 \text { proportion }\end{array}$ & Pro-inflammatory status & $\begin{array}{c}\uparrow \text { Enterobacteriaceae, } \\
\text { Segmented Filamentous } \\
\text { Bacteria and Clostridia. }\end{array}$ & $\begin{array}{c}\uparrow \text { Metabolic endotoxemia } \downarrow \\
\text { Production of PUFAs } \\
\text { metabolites }\end{array}$ & $\begin{array}{l}\text { Increase the intake of omega } \\
\text { 3-enriched foods and reduce } \\
\text { omega } 6 \text { foods }\end{array}$ & [212], [374-376] \\
\hline Trans fats & $\begin{array}{l}\text { Naturally in ruminant } \\
\text { meats and UPFDs }\end{array}$ & $\begin{array}{l}\text { Less than } 1 \% \text { of daily } \\
\text { caloric intake }\end{array}$ & $\begin{array}{l}\uparrow \text { Low grade chronic } \\
\text { inflammation }\end{array}$ & $\begin{array}{c}\text { Promotion of gut } \\
\text { dysbiosis, particularly } \\
\text { affecting BA producers } \\
\text { bacteria }\end{array}$ & $\begin{array}{l}\uparrow \text { Intestinal permeability, } \\
\text { disruption of } \\
\text { enteroendocrine cells }\end{array}$ & $\begin{array}{l}\text { As it is prominently associated } \\
\text { with ultra-processing, it } \\
\text { should be avoided }\end{array}$ & $\begin{array}{c}{[182]} \\
{[362-367]}\end{array}$ \\
\hline
\end{tabular}


Table 2. Cont

\begin{tabular}{|c|c|c|c|c|c|c|c|}
\hline $\begin{array}{l}\text { Nutritional } \\
\text { Component }\end{array}$ & Top Food Sources & $\begin{array}{c}\text { Maximum Intake } \\
\text { Limits Per Day/Week }\end{array}$ & Immunomodulation & $\begin{array}{l}\text { Gut Microbiota } \\
\text { Modulation }\end{array}$ & $\begin{array}{l}\text { Intestinal Barrier Damage } \\
\text { and Other } \\
\text { Pathological Effects }\end{array}$ & $\begin{array}{c}\text { Alternatives/Substitutes and } \\
\text { Suggestions }\end{array}$ & Ref \\
\hline Refined oils & $\begin{array}{l}\text { UPFDs, precooked } \\
\text { foods }\end{array}$ & & $\begin{array}{l}\text { Pro-inflammatory } \\
\text { cytokines } \uparrow\end{array}$ & $\begin{array}{c}\text { Refined palm oil } \\
\downarrow \text { Akkermansia } \\
\text { muciniphila, SFB, and } \\
\text { Clostridium leptum } \\
\text { growth } \\
\text { Refined olive oil } \\
\uparrow \text { Desulfovibrionaceae, } \\
\text { Spiroplasmataceae, and } \\
\text { Helicobacteraceae along } \\
\text { with } \\
\text { Erysipelotrichaceae and } \\
\text { Sutterellaceae } \downarrow \\
\text { Sunflower oil } \\
\uparrow \text { Sphingomonas and } \\
\text { Neisseria spp. while } \\
\downarrow \text { Akkermansia } \\
\text { muciniphilla and } \\
\text { Bifidobacterium spp. } \\
\text { Coconut oil } \\
\downarrow \text { Akkermansia } \\
\text { muciniphilla abundance } \\
\text { and } \uparrow \text { Staphylococcus, } \\
\text { Prevotella and Bacteroides } \\
\text { sp. }\end{array}$ & $\uparrow$ Intestinal permeability & $\begin{array}{l}\text { Cooking with EVOO, or } \\
\text { non-refined oils; look carefully } \\
\text { at nutritional labeling, reduce } \\
\text { precooked foods }\end{array}$ & [368-373] \\
\hline $\begin{array}{l}\text { Red and processed } \\
\text { meats components } \\
\text { over-consumption }\end{array}$ & $\begin{array}{l}\text { Beef, veal, pork, lamb, } \\
\text { mutton, horse, or goat } \\
\text { meat consumed directly } \\
\text { or after further } \\
\text { processing (sausages, } \\
\text { corned beef, and biltong } \\
\text { or beef jerky) }\end{array}$ & & $\begin{array}{l}\text { Neu5Gc contained in } \\
\text { red meat, N-nitroso } \\
\text { compounds TMA } \\
\text { produced by red and } \\
\text { processed meat } \\
\text { precursors under } \\
\text { conditions of dysbiosis } \\
\text { may exert } \\
\text { pro-inflammatory } \\
\text { effects }\end{array}$ & $\begin{array}{l}\text { Changes in certain } \\
\text { microbial populations } \\
\text { like Fusobacterium } \\
\text { nucleatum, Streptococcus } \\
\text { bovis/gallolyticus, } \\
\text { Escherichia coli, and } \\
\text { Bacteroides fragilis }\end{array}$ & $\begin{array}{l}\text { Altering intestinal barrier } \uparrow \\
\text { Hyperproliferation of } \\
\text { colonic enterocytes and } \\
\text { correlation with colorectal } \\
\text { cancer }\end{array}$ & $\begin{array}{l}\text { Red meat is not a central } \\
\text { component of the human diet } \\
\text { and it could be completely } \\
\text { displaced. However, it might } \\
\text { be equally included in a } \\
\text { healthy diet, although } \\
\text { moderately (Not superior to } 2 \\
\text { to } 3 \text { portions per week or } \\
350-500 \text { g according to AICR } \\
\text { guidelines) } \\
\text { Avoid or further limit } \\
\text { processed meats consumption }\end{array}$ & $\begin{array}{l}{[377-380]} \\
{[383-385]}\end{array}$ \\
\hline
\end{tabular}


Table 2. Cont.

\begin{tabular}{|c|c|c|c|c|c|c|c|}
\hline $\begin{array}{l}\text { Nutritional } \\
\text { Component }\end{array}$ & Top Food Sources & $\begin{array}{c}\text { Maximum Intake } \\
\text { Limits Per Day/Week }\end{array}$ & Immunomodulation & $\begin{array}{l}\text { Gut Microbiota } \\
\text { Modulation }\end{array}$ & $\begin{array}{c}\text { Intestinal Barrier Damage } \\
\text { and Other } \\
\text { Pathological Effects }\end{array}$ & $\begin{array}{c}\text { Alternatives/Substitutes and } \\
\text { Suggestions }\end{array}$ & Ref \\
\hline Salt & UPFDs & $<5$ g per day & $\begin{array}{l}\text { Affecting gut } \\
\text { microbiota-Th17 axis }\end{array}$ & $\begin{array}{c}\downarrow \text { Lactobacillus sp. } \\
\text { Oscillibacter, } \\
\text { Pseudoflavonifractor, } \\
\text { Clos-tridium XIVa } \\
\text { Johnsonella and Rothia } \\
\uparrow \text { Parasutterella spp. } \\
\text { Erwinia genus, } \\
\text { Christensenellaceae, } \\
\text { Corynebacteriaceae } \\
\text { Lachnospiraceae and } \\
\text { Ruminococcus }\end{array}$ & $\begin{array}{l}\text { Promoting hypertension } \\
\text { and CVD risk }\end{array}$ & $\begin{array}{l}\text { Avoid consumption of } \\
\text { high-salt foods, particularly } \\
\text { ultra-processed. It is possible } \\
\text { to cook with salt, but at } \\
\text { moderate doses. Maintaining } \\
\text { a proper balance of Na+ and } \\
\text { K+ should help to avoid } \\
\text { systemic defects of salt }\end{array}$ & [391-395] \\
\hline Additives & $\begin{array}{c}\text { UPFDs } \\
\text { Processed foods }\end{array}$ & - & $\begin{array}{l}\text { Low } / \text { non caloric } \\
\text { sweeteners are } \\
\text { associated with a } \\
\text { pro-inflammatory } \\
\text { switch }\end{array}$ & $\begin{array}{c}\downarrow \text { Lactobacillus and } \\
\text { Bifidobacteria } \\
\text { microorganisms; } \\
\uparrow \text { pathogenic bacteria } \\
\\
\text { Polyalcohols may act } \\
\text { favorably in gut } \\
\text { microbiota, acting like } \\
\text { prebiotics } \\
\uparrow \text { Bifidobacterium and } \\
\text { Lactobacillus }\end{array}$ & $\begin{array}{l}\uparrow \text { Gut permeability, glucose } \\
\text { intolerance, weight gain }\end{array}$ & $\begin{array}{l}\text { Additives are a difficult } \\
\text { component of diet to study, } \\
\text { and most of them are } \\
\text { inocuous or necessary for food } \\
\text { conserving. However, some of } \\
\text { them have provided } \\
\text { accumulative evidence of their } \\
\text { potential negative effects, so } \\
\text { avoiding their consumption } \\
\text { should be suitable }\end{array}$ & [396-401] \\
\hline
\end{tabular}

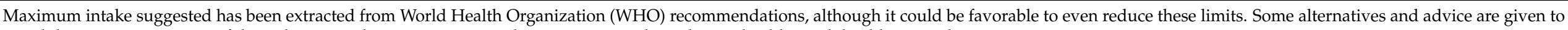
avoid the overconsumption of these detrimental components, in order to progressively replace unhealthy with healthy ingredients. 


\section{Conclusions and Future Directions}

The gut microbiota is considered by some authors as a single organ [402], playing critical roles in host homeostasis, and different microbial communities may directly influence the immune system. As summarized in Figure 3, diet must be the most important environmental factor positively or negatively affecting both gut microbiota and immune system, although many other elements should be considered to fully understand this complex interplay.

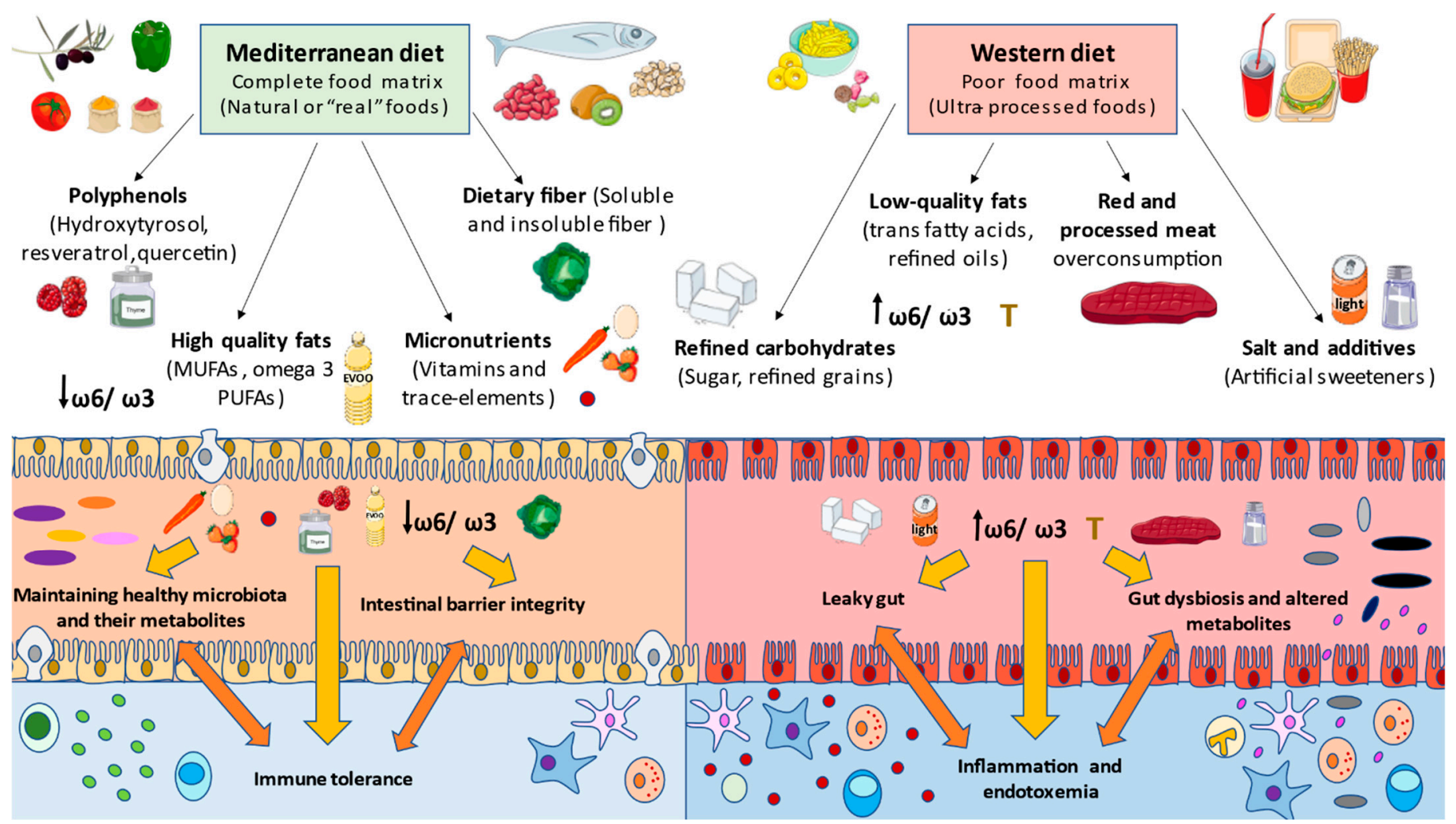

Figure 3. A general overview of the main nutritional components modulating both gut microbiota and immune system. As it is represented, the Mediterranean diet, rich in plant-based aliments, presents polyphenols, high-quality fats (MUFAs and high omega 3 PUFAs), micronutrients, such as vitamins and trace elements, and dietary fiber that, in an adequate and complete food matrix, will determine their beneficial properties in maintaining gut microbiota eubiosis and its metabolic products, along with intestinal barrier integrity and immune tolerance. On the other side, western diets and ultra-processed foods, characterized by low levels of dietary fiber or micronutrients, present a plethora of nutritional components, including refined carbohydrates (sugar and refined grains), low-quality fats (trans fatty acids and an excessive omega 6/omega 3 ratio due to the refined oils), salt and unhealthy additives (mainly sweeteners), and finally excessive red and processed meat consumption. Moreover, they comprise a poor food matrix that will have detrimental effects at the intestinal barrier, leading to leaky gut, gut dysbiosis and altered metabolites, further leading to a local inflammation and the presence of LPS in the bloodstream that will contribute to systemic endotoxemia and chronic inflammation.

As described, each dietary component has a direct impact on host health through the intestinal epithelial barrier, commensal bacteria and thus cell immunophenotypes, and their pro-inflammatory or anti-inflammatory responses. Due to their beneficial properties, some nutritional components found in nutrient-rich and high-quality balanced diets like MD keep offering valuable information in terms of the clinical management of the NCDs burden. With the aim of leveraging the anti-inflammatory and antioxidant potential of polyphenols, nutraceuticals research based on these phytochemicals seems to be of great interest [403], thus improving their bioavailability and absorption properties, and even facilitating glucuronidation or sulfation forms as well, these being biologically active for patients with metabolic disorders. Further work is warranted in immunotherapy 
with vitamins as well, as these are promising adjuvants for a wide spectrum of diseases, including inflammatory diseases [404], cancer [405] and depression [406], as well as in the prevention of these NCDs, among others.

The human being is more susceptible to infections in the first or last years of life, and even more so without a proper diet [407]. The period of the first stage of life seems to be critical in the maturation of the immune system, and is also named the "window of opportunity" [6], having an impact not only on physical development but also on neurocognitive and disease risks [408]. On the one hand, in the early life, nutritional strategies are pursued in order to prevent NCDs such as asthma or allergies in adulthood [409], which involve considering breastfeeding [410], or including prebiotics or human milk oligosaccharides (HMO) in formula feeding for infants [411,412], as well as providing fiber and PUFA to the mother during pregnancy [413]. All these nutrients will favor the epigenetic mechanisms that may have an effect in later life, and which will shape the immunophenotype differentiation to Th1, Th2, Th17 or Treg [414]. Despite the fact that the food industry makes advances in infant formula products, as a result of evolution, breastfeeding is the first contact of the human body with natural prebiotics. Likewise, other components from human milk interact with the baby's immune system, for example PUFAs, cytokines, allergens, immunoglobulins, and chemokines [415], although some Bifidobacterium species are also able to take glycans from the mother's milk [416].

On the other hand, aging is another critical event in which gut microbiota may have a central role, as immune competence shrinks with aging, an event referred to as immunosenescence and inflammaging [417]. Focusing on healthy aging, the current studies are attempting to ameliorate quality of life in the elderly [418]. In this line, neurodegeneration and the associated neuroinflammation cause reductions in the diversity of beneficial bacteria, such as Lactobacilli $[419,420]$, and debunk the hypothesis that microbes have a direct impact on host aging [421].

In summary, the diet modulates both immune system and gut microbiota at the same time, establishing a bidirectional dialogue with signaling pathways or metabolite production, which affect each other functions.

In the event of malnutrition, deficiencies in micronutrients are quite common, and determinant of the physiopathology of immunodeficiencies and inflammatory diseases. Such are the cases of NCDs, obesity, T2DM, MetS, CVD, and IBD, among others. These maladies are typically prevalent in developed countries, where WD patterns are the norm. WD is characterized by high carbohydrate and saturated fat intakes, and includes a low-quality "food matrix", which is refined and ultra-processed with added sugars and additives. In contrast, adherence to an MD may ameliorate inflammation and gut microbiota dysbiosis, thanks to its abundance in PUFAs, dietary fiber, polyphenols, vitamins and trace elements, all necessary for achieving an adequate balance of Th17/Treg in the host and guaranteeing high microbial diversity.

Nutritional deficiencies should be addressed personally, evaluating the patient's health status and making some recommendations not only as regards supplementations, but also in terms of healthy dietary habits. However, dietary components cannot be treated individually. Deficiencies in any micronutrient, and sometimes also excesses, can be crucial for the outbreak of an opportunistic pathogen and the reduction of beneficial bacteria, such as Lactobacillus and Bifidobacterium. Therefore, in malnutrition treatment, targeting microbiota reprogramming involves probiotics together with the nutritional component that is scarce, as certain bacteria help those nutraceuticals to grow, and provide SCFA or other metabolites to achieve host immunocompetence.

Author Contributions: Conceptualization, C.G.-M., O.F.-M., M.Á.-M., M.A.Á.-M., M.A.O.; methodology, C.G.-M., O.F.-M., A.M.G.-L., M.A.Á.-M., M.A.O.; validation, J.M., M.Á.-M., M.A.Á.-M., M.A.O.; formal analysis, C.G-M., O.F.-M., A.M.G.-L., L.P., A.J.C., F.N.-F., L.S.-T., A.A.; investigation, C.G.-M., O.F.-M., A.M.G.-L., L.P., A.J.C., S.C., L.G.G., N.G.-H., A.A., G.L., J.B., M.A.O.; resources, S.C., J.B., J.M., M.Á.-M.; data curation, F.N.-F., L.G.G., G.L., J.M., M.A.Á.-M.; writing—original draft preparation, C.G.-M., O.F.-M., A.M.G.-L., L.P., A.J.C., G.L., J.B., M.Á.-M., M.A.Á.-M., M.A.O.; writing-review 
and editing, C.G.-M., O.F.-M., A.M.G.-L., L.G.G., N.G.-H., A.A., G.L., J.B., J.M., M.Á.-M., M.A.Á.-M., M.A.O.; supervision, S.C., A.A., G.L., J.B., J.M., M.Á.-M.; project administration, J.B., J.M., M.Á.-M., M.A.O.; funding acquisition, J.B., J.M., M.Á.-M. All authors have read and agreed to the published version of the manuscript.

Funding: This work was partially supported by grants from the Fondo de Investigación de la Seguridad Social, Instituto de Salud Carlos III (PI18/01726), Spain, Programa de Actividades de I+D de la Comunidad de Madrid en Biomedicina (B2017/BMD3804), Madrid, Spain and Instituto de Salud Carlos III CIBER Enfermedades hepáticas y Digestivas, Spain.

Conflicts of Interest: The authors declare no conflict of interest.

\section{References}

1. Postler, T.S.; Ghosh, S. Understanding the Holobiont: How Microbial Metabolites Affect Human Health and Shape the Immune System. Cell Metab. 2017, 26, 110-130. [CrossRef]

2. Cresci, G.A.; Bawden, E. Gut microbiome: What we do and don't know. Nutr. Clin. Pract. 2015, 30, 734-746. [CrossRef]

3. Heintz-Buschart, A.; Wilmes, P. Human Gut Microbiome: Function Matters. Trends Microbiol. 2018, 26, 563-574. [CrossRef]

4. Levy, M.; Blacher, E.; Elinav, E. Microbiome, metabolites and host immunity. Curr. Opin. Microbiol. 2017, 35, 8-15. [CrossRef]

5. Derovs, A.; Laivacuma, S.; Krumina, A. Targeting microbiota: What do we know about it at present? Medicina 2019, 55, 459. [CrossRef]

6. Gensollen, T.; Iyer, S.S.; Kasper, D.L.; Blumberg, R.S. How colonization by microbiota in early life shapes the immune system. Science 2016, 352, 539-544. [CrossRef]

7. Hand, T.W.; Vujkovic-Cvijin, I.; Ridaura, V.K.; Belkaid, Y. Linking the Microbiota, Chronic Disease, and the Immune System. Trends Endocrinol. Metab. 2016, 27, 831-843. [CrossRef]

8. Childs, C.E.; Calder, P.C.; Miles, E.A. Diet and immune function. Nutrients 2019, 11, 1933. [CrossRef]

9. Kolodziejczyk, A.A.; Zheng, D.; Elinav, E. Diet-microbiota interactions and personalized nutrition. Nat. Rev. Microbiol. 2019, 17, 742-753. [CrossRef]

10. Marchesi, J.R.; Adams, D.H.; Fava, F.; Hermes, G.D.A.; Hirschfield, G.M.; Hold, G.; Quraishi, M.N.; Kinross, J.; Smidt, H.; Tuohy, K.M.; et al. The gut microbiota and host health: A new clinical frontier. Gut 2016, 65, 330-339. [CrossRef]

11. Greer, R.; Dong, X.; Morgun, A.; Shulzhenko, N. Investigating a holobiont: Microbiota perturbations and transkingdom networks. Gut Microbes 2016, 7, 1-10. [CrossRef] [PubMed]

12. Tierney, B.T.; Yang, Z.; Luber, J.M.; Beaudin, M.; Wibowo, M.C.; Baek, C.; Mehlenbacher, E.; Patel, C.J.; Kostic, A.D. The Landscape of Genetic Content in the Gut and Oral Human Microbiome. Cell Host Microbe 2019, 26, 283-295. [CrossRef]

13. NIH Human Microbiome Project. Available online: https://www.hmpdacc.org/hmp/ (accessed on 26 September 2020).

14. Bilen, M.; Dufour, J.C.; Lagier, J.C.; Cadoret, F.; Daoud, Z.; Dubourg, G.; Raoult, D. The contribution of culturomics to the repertoire of isolated human bacterial and archaeal species. Microbiome 2018, 6, 94. [CrossRef]

15. Turpin, W.; Espin-Garcia, O.; Xu, W.; Silverberg, M.S.; Kevans, D.; Smith, M.I.; Guttman, D.S.; Griffiths, A.; Panaccione, R.; Otley, A.; et al. Association of host genome with intestinal microbial composition in a large healthy cohort. Nat. Genet. 2016, 48, 1413-1417. [CrossRef]

16. Adak, A.; Khan, M.R. An insight into gut microbiota and its functionalities. Cell. Mol. Life Sci. 2019, 76, 473-493. [CrossRef]

17. Costea, P.I.; Hildebrand, F.; Manimozhiyan, A.; Bäckhed, F.; Blaser, M.J.; Bushman, F.D.; De Vos, W.M.; Ehrlich, S.D.; Fraser, C.M.; Hattori, M.; et al. Enterotypes in the landscape of gut microbial community composition. Nat. Microbiol. 2017, 3, 8-16. [CrossRef]

18. Rajilić-Stojanović, M.; Jonkers, D.M.; Salonen, A.; Hanevik, K.; Raes, J.; Jalanka, J.; De Vos, W.M.; Manichanh, C.; Golic, N.; Enck, P.; et al. Intestinal microbiota and diet in IBS: Causes, consequences, or epiphenomena? Am. J. Gastroenterol. 2015, 110, $278-287$. [CrossRef]

19. Rinninella, E.; Raoul, P.; Cintoni, M.; Franceschi, F.; Miggiano, G.A.D.; Gasbarrini, A.; Mele, M.C. What is the healthy gut microbiota composition? A changing ecosystem across age, environment, diet, and diseases. Microorganisms $2019,7,14$. [CrossRef] [PubMed]

20. Rizzatti, G.; Lopetuso, L.R.; Gibiino, G.; Binda, C.; Gasbarrini, A. Proteobacteria: A common factor in human diseases. Biomed. Res. Int. 2017, 2017. [CrossRef] [PubMed]

21. Thursby, E.; Juge, N. Introduction to the human gut microbiota. Biochem. J. 2017, 474, 1823-1836. [CrossRef] [PubMed]

22. Shkoporov, A.N.; Clooney, A.G.; Sutton, T.D.S.; Ryan, F.J.; Daly, K.M.; Nolan, J.A.; McDonnell, S.A.; Khokhlova, E.V.; Draper, L.A.; Forde, A.; et al. The Human Gut Virome Is Highly Diverse, Stable, and Individual Specific. Cell Host Microbe 2019, $26,527-541$. [CrossRef]

23. Rascovan, N.; Duraisamy, R.; Desnues, C. Metagenomics and the Human Virome in Asymptomatic Individuals. Annu. Rev. Microbiol. 2016, 70, 125-141. [CrossRef] [PubMed]

24. Domínguez-Díaz, C.; García-Orozco, A.; Riera-Leal, A.; Padilla-Arellano, J.R.; Fafutis-Morris, M. Microbiota and its role on viral evasion: Is it with us or against us? Front. Cell. Infect. Microbiol. 2019, 9, 256. [CrossRef] [PubMed]

25. Manrique, P.; Dills, M.; Young, M.J. The human gut phage community and its implications for health and disease. Viruses 2017, 9, 141. [CrossRef] [PubMed] 
26. Scarpellini, E.; Ianiro, G.; Attili, F.; Bassanelli, C.; De Santis, A.; Gasbarrini, A. The human gut microbiota and virome: Potential therapeutic implications. Dig. Liver Dis. 2015, 47, 1007-1012. [CrossRef] [PubMed]

27. Matarazzo, F.; Ribeiro, A.C.; Faveri, M.; Taddei, C.; Martinez, M.B.; Mayer, M.P.A. The domain Archaea in human mucosal surfaces. Clin. Microbiol. Infect. 2012, 18, 834-840. [CrossRef]

28. Dridi, B.; Raoult, D.; Drancourt, M. Archaea as emerging organisms in complex human microbiomes. Anaerobe 2011, 17, 56-63. [CrossRef]

29. Kapitan, M.; Niemiec, M.J.; Steimle, A.; Frick, J.S.; Jacobsen, I.D. Fungi as part of the microbiota and interactions with intestinal Bacteria. In Current Topics in Microbiology and Immunology; Springer: Berlin, Germany, 2019; Volume 422, pp. $265-301$.

30. Chabé, M.; Lokmer, A.; Ségurel, L. Gut Protozoa: Friends or Foes of the Human Gut Microbiota? Trends Parasitol. 2017, 33, 925-934. [CrossRef]

31. Harris, N.L. Intimate gut interactions: Helminths and the microbiota. Cell Res. 2016, 26, 861-862. [CrossRef]

32. Donaldson, G.P.; Lee, S.M.; Mazmanian, S.K. Gut biogeography of the bacterial microbiota. Nat. Rev. Microbiol. 2015, 14, 20-32. [CrossRef]

33. Minton, K. Microbiota: Pathobiont peacekeepers. Nat. Rev. Immunol. 2018, 18, 152. [CrossRef] [PubMed]

34. Abisado, R.G.; Benomar, S.; Klaus, J.R.; Dandekar, A.A.; Chandler, J.R. Bacterial quorum sensing and microbial community interactions. MBio 2018, 9. [CrossRef]

35. Thompson, J.A.; Oliveira, R.A.; Djukovic, A.; Ubeda, C.; Xavier, K.B. Manipulation of the quorum sensing signal AI-2 affects the antibiotic-treated gut microbiota. Cell Rep. 2015, 10, 1861-1871. [CrossRef]

36. Iseppi, R.; Messi, P.; Camellini, S.; Sabia, C. Bacteriocin activity of Lactobacillus brevis and Lactobacillus paracasei ssp. paracasei. J. Med. Microbiol. 2019, 68, 1359-1366. [CrossRef]

37. Martinez, F.A.C.; Balciunas, E.M.; Converti, A.; Cotter, P.D.; De Souza Oliveira, R.P. Bacteriocin production by Bifidobacterium spp. A review. Biotechnol. Adv. 2013, 31, 482-488. [CrossRef] [PubMed]

38. Iebba, V.; Totino, V.; Gagliardi, A.; Santangelo, F.; Cacciotti, F.; Trancassini, M.; Mancini, C.; Cicerone, C.; Corazziari, E.; Pantanella, F.; et al. Eubiosis and dysbiosis: The two sides of the microbiota. New Microbiol. 2016, 39, 1-2. [PubMed]

39. Hooks, K.B.; O’Malley, M.A. Dysbiosis and Its Discontents. MBio 2017. [CrossRef] [PubMed]

40. Tan, J.; McKenzie, C.; Potamitis, M.; Thorburn, A.N.; Mackay, C.R.; Macia, L. The Role of Short-Chain Fatty Acids in Health and Disease. Adv Immunol. 2014, 121, 91-119. [CrossRef] [PubMed]

41. LeBlanc, J.G.; Chain, F.; Martín, R.; Bermúdez-Humarán, L.G.; Courau, S.; Langella, P. Beneficial effects on host energy metabolism of short-chain fatty acids and vitamins produced by commensal and probiotic bacteria. Microb. Cell Fact. 2017, 16, 79. [CrossRef]

42. Flint, H.J.; Duncan, S.H.; Scott, K.P.; Louis, P. Links between diet, gut microbiota composition and gut metabolism. Proc. Nutr. Soc. 2015, 74, 13-22. [CrossRef]

43. Agus, A.; Planchais, J.; Sokol, H. Gut Microbiota Regulation of Tryptophan Metabolism in Health and Disease. Cell Host Microbe 2018, 23, 716-724. [CrossRef]

44. Das, A.; Srinivasan, M.; Ghosh, T.S.; Mande, S.S. Xenobiotic metabolism and gut microbiomes. PLoS ONE 2016, 11, e0163099. [CrossRef]

45. Rowland, I.; Gibson, G.; Heinken, A.; Scott, K.; Swann, J.; Thiele, I.; Tuohy, K. Gut microbiota functions: Metabolism of nutrients and other food components. Eur. J. Nutr. 2018, 57, 1. [CrossRef]

46. Ramírez-Pérez, O.; Cruz-Ramón, V.; Chinchilla-López, P.; Méndez-Sánchez, N. The role of the gut microbiota in bile acid metabolism. Ann. Hepatol. 2017, 16, S21-S26. [CrossRef] [PubMed]

47. Sitkin, S.I.; Tkachenko, E.I.; Vakhitov, T.Y. Metabolic dysbiosis of the gut microbiota and its biomarkers. Eksp. Klin. Gastroenterol. 2016, 12, 6-29. [PubMed]

48. Cryan, J.F.; O’Riordan, K.J.; Cowan, C.S.M.; Sandhu, K.V.; Bastiaanssen, T.F.S.; Boehme, M.; Codagnone, M.G.; Cussotto, S.; Fulling, C.; Golubeva, A.V.; et al. The microbiota-gut-brain axis. Physiol. Rev. 2019, 99, 1877-2013. [CrossRef] [PubMed]

49. Quach, D.; Britton, R.A. Gut Microbiota and Bone Health. Adv. Exp. Med. Biol. 2017, 1033, 47-58. [CrossRef]

50. Wang, Z.; Zhao, Y. Gut microbiota derived metabolites in cardiovascular health and disease. Protein Cell 2018, 9, 416-431. [CrossRef]

51. Levy, M.; Kolodziejczyk, A.A.; Thaiss, C.A.; Elinav, E. Dysbiosis and the immune system. Nat. Rev. Immunol. 2017, 17, 219-232. [CrossRef]

52. Sirisinha, S. The potential impact of gut microbiota on your health: Current status and future challenges. Asian Pacific J. Allergy Immunol. 2016, 34, 249-264.

53. Li, D.; Wang, P.; Wang, P.; Hu, X.; Chen, F. The gut microbiota: A treasure for human health. Biotechnol. Adv. 2016, 34, 1210-1224. [CrossRef]

54. Kriss, M.; Hazleton, K.Z.; Nusbacher, N.M.; Martin, C.G.; Lozupone, C.A. Low diversity gut microbiota dysbiosis: Drivers, functional implications and recovery. Curr. Opin. Microbiol. 2018, 44, 34-40. [CrossRef] [PubMed]

55. Youmans, B.P.; Ajami, N.J.; Jiang, Z.D.; Campbell, F.; Duncan Wadsworth, W.; Petrosino, J.F.; Du-Pont, H.L.; Highlander, S.K. Characterization of the human gut microbiome during travelers' diarrhea. Gut Microbes 2015, 6, 110-119. [CrossRef] [PubMed]

56. Gomes, A.C.; Hoffmann, C.; Mota, J.F. The human gut microbiota: Metabolism and perspective in obesity. Gut Microbes 2018, 9, 308-325. [CrossRef] 
57. Ortega, M.A.; Fraile-Martínez, O.; Naya, I.; García-Honduvilla, N.; Álvarez-Mon, M.; Buján, J.; Asúnsolo, Á.; de la Torre, B. Type 2 Diabetes Mellitus Associated with Obesity (Diabesity). The Central Role of Gut Microbiota and Its Translational Applications. Nutrients 2020, 12, 2749. [CrossRef] [PubMed]

58. Magne, F.; Gotteland, M.; Gauthier, L.; Zazueta, A.; Pesoa, S.; Navarrete, P.; Balamurugan, R. The firmicutes/bacteroidetes ratio: A relevant marker of gut dysbiosis in obese patients? Nutrients 2020, 12, 1474. [CrossRef]

59. Shin, N.R.; Whon, T.W.; Bae, J.W. Proteobacteria: Microbial signature of dysbiosis in gut microbiota. Trends Biotechnol. 2015, 33, 496-503. [CrossRef]

60. Binda, C.; Lopetuso, L.R.; Rizzatti, G.; Gibiino, G.; Cennamo, V.; Gasbarrini, A. Actinobacteria: A relevant minority for the maintenance of gut homeostasis. Dig. Liver Dis. 2018, 50, 421-428. [CrossRef] [PubMed]

61. Macchione, I.G.; Lopetuso, L.R.; Ianiro, G.; Napol, M.; Gibiino, G.; Rizzatt, G.; Petito, V.; Gasbarrini, A.; Scaldaferri, F. Akkermansia muciniphila: Key player in metabolic and gastrointestinal disorders. Eur. Rev. Med. Pharmacol. Sci. 2019, 23, 8075-8083. [CrossRef] [PubMed]

62. Das, B.; Balakrish Nair, G. Homeostasis and dysbiosis of the gut microbiome in health and disease. J. Biosci. 2019. [CrossRef]

63. Lewis, J.D.; Chen, E.Z.; Baldassano, R.N.; Otley, A.R.; Griffiths, A.M.; Lee, D.; Bittinger, K.; Bailey, A.; Friedman, E.S.; Hoffmann, C.; et al. Inflammation, Antibiotics, and Diet as Environmental Stressors of the Gut Microbiome in Pediatric Crohn's Disease. Cell Host Microbe 2015, 18, 489-500. [CrossRef]

64. Luan, H.; Wang, X.; Cai, Z. Mass spectrometry-based metabolomics: Targeting the crosstalk between gut microbiota and brain in neurodegenerative disorders. Mass Spectrom. Rev. 2019, 38, 22-33. [CrossRef]

65. Nishida, A.; Inoue, R.; Inatomi, O.; Bamba, S.; Naito, Y.; Andoh, A. Gut microbiota in the pathogenesis of inflammatory bowel disease. Clin. J. Gastroenterol. 2018, 11, 1-10. [CrossRef]

66. Andreasen, A.; Krabbe, K.; Krogh-Madsen, R.; Taudorf, S.; Pedersen, B.; Moller, K. Human Endotoxemia as a Model of Systemic Inflammation. Curr. Med. Chem. 2008, 15, 1697-1705. [CrossRef] [PubMed]

67. Ensari, A.; Marsh, M.N. Exploring the villus. Gastroenterol. Hepatol. Bed Bench 2018, 11, 181-190. [PubMed]

68. Umar, S. Intestinal stem cells. Curr. Gastroenterol. Rep. 2010, 12, 340-348. [CrossRef] [PubMed]

69. Snoeck, V.; Goddeeris, B.; Cox, E. The role of enterocytes in the intestinal barrier function and antigen uptake. Microbes Infect. 2005, 7, 997-1004. [CrossRef] [PubMed]

70. Dao, D.-P.D.; Le, P.H. Histology, Goblet Cells; StatPearls Publishing: Treasure Island, FL, USA, 2020.

71. Banerjee, A.; McKinley, E.T.; Von Moltke, J.; Coffey, R.J.; Lau, K.S. Interpreting heterogeneity in intestinal tuft cell structure and function. J. Clin. Investig. 2018, 128, 1711-1719. [CrossRef] [PubMed]

72. Gerbe, F.; Sidot, E.; Smyth, D.J.; Ohmoto, M.; Matsumoto, I.; Dardalhon, V.; Cesses, P.; Garnier, L.; Pouzolles, M.; Brulin, B.; et al. Intestinal epithelial tuft cells initiate type 2 mucosal immunity to helminth parasites. Nature 2016, 529, 226-230. [CrossRef]

73. Lueschow, S.R.; McElroy, S.J. The Paneth Cell: The Curator and Defender of the Immature Small Intestine. Front. Immunol. 2020, 11, 587. [CrossRef]

74. Simmonds, N.; Furman, M.; Karanika, E.; Phillips, A.; Bates, A.W.H. Paneth cell metaplasia in newly diagnosed inflammatory bowel disease in children. BMC Gastroenterol. 2014, 14, 93. [CrossRef]

75. Gribble, F.M.; Reimann, F. Enteroendocrine Cells: Chemosensors in the Intestinal Epithelium. Annu. Rev. Physiol. 2016, 78, 277-299. [CrossRef] [PubMed]

76. Ahluwalia, B.; Magnusson, M.K.; Öhman, L. Mucosal immune system of the gastrointestinal tract: Maintaining balance between the good and the bad. Scand. J. Gastroenterol. 2017, 52, 1185-1193. [CrossRef] [PubMed]

77. Shields, J.W. The functional evolution of GALT: A review-PubMed. Lympholohy 2000, 33, 47-57.

78. Helander, H.F.; Fändriks, L. Surface area of the digestive tract-revisited. Scand. J. Gastroenterol. 2014, 49, 681-689. [CrossRef]

79. Iweala, O.I.; Nagler, C.R. The Microbiome and Food Allergy. Annu. Rev. Immunol. 2019, 37, 377-403. [CrossRef]

80. Habtezion, A.; Nguyen, L.P.; Hadeiba, H.; Butcher, E.C. Leukocyte Trafficking to the Small Intestine and Colon. Gastroenterology 2016, 150, 340-354. [CrossRef]

81. Olivares-Villagómez, D.; Van Kaer, L. Intestinal Intraepithelial Lymphocytes: Sentinels of the Mucosal Barrier. Trends Immunol. 2018, 39, 264-275. [CrossRef]

82. Kobayashi, N.; Takahashi, D.; Takano, S.; Kimura, S.; Hase, K. The Roles of Peyer's Patches and Microfold Cells in the Gut Immune System: Relevance to Autoimmune Diseases. Front. Immunol. 2019, 10, 2345. [CrossRef]

83. Ohno, H. Intestinal M cells. J. Biochem. 2015, 159, 151-160. [CrossRef] [PubMed]

84. Reboldi, A.; Cyster, J.G. Peyer's patches: Organizing B-cell responses at the intestinal frontier. Immunol. Rev. 2016, 271, 230-245. [CrossRef] [PubMed]

85. Wells, J.M.; Rossia, O.; Meijerink, M.; Van Baarlen, P. Epithelial crosstalk at the microbiota-mucosal interface. Proc. Natl. Acad. Sci. USA 2011, 108, 4607-4614. [CrossRef]

86. Belkaid, Y.; Hand, T.W. Role of the microbiota in immunity and inflammation. Cell 2014, 157, 121-141. [CrossRef] [PubMed]

87. Corridoni, D.; Chapman, T.; Ambrose, T.; Simmons, A. Emerging mechanisms of innate immunity and their translational potential in inflammatory bowel disease. Front. Med. 2018, 5, 32. [CrossRef]

88. Levy, M.; Thaiss, C.A.; Elinav, E. Metabolites: Messengers between the microbiota and the immune system. Genes Dev. 2016, 30, 1589-1597. [CrossRef] [PubMed]

89. Thaiss, C.A.; Zmora, N.; Levy, M.; Elinav, E. The microbiome and innate immunity. Nature 2016, 535, 65-74. [CrossRef] [PubMed] 
90. Honda, K.; Littman, D.R. The microbiota in adaptive immune homeostasis and disease. Nature 2016, 535, 75-84. [CrossRef] [PubMed]

91. Muñoz, L.; Borrero, M.J.; Úbeda, M.; Conde, E.; del Campo, R.; Rodríguez-Serrano, M.; Lario, M.; Sánchez-Díaz, A.M.; Pastor, O.; Díaz, D.; et al. Intestinal Immune Dysregulation Driven by Dysbiosis Promotes Barrier Disruption and Bacterial Translocation in Rats with Cirrhosis. Hepatology 2019, 70, 925-938. [CrossRef]

92. Albillos, A.; de la Hera, A.; González, M.; Moya, J.L.; Calleja, J.L.; Monserrat, J.; Ruiz-del-Arbol, L.; Alvarez-Mon, M. Increased lipopolysaccharide binding protein in cirrhotic patients with marked immune and hemodynamic derangement. Hepatology 2003, 37, 208-217. [CrossRef]

93. Alvarez-Mon, M.A.; Gómez, A.M.; Orozco, A.; Lahera, G.; Sosa, M.D.; Diaz, D.; Auba, E.; Albillos, A.; Monserrat, J.; Alvarez-Mon, M. Abnormal Distribution and Function of Circulating Monocytes and Enhanced Bacterial Translocation in Major Depressive Disorder. Front. Psychiatry 2019, 10. [CrossRef]

94. Dehner, C.; Fine, R.; Kriegel, M.A. The microbiome in systemic autoimmune disease: Mechanistic insights from recent studies. Curr. Opin. Rheumatol. 2019, 31, 201-207. [CrossRef]

95. Kayagaki, N.; Wong, M.T.; Stowe, I.B.; Ramani, S.R.; Gonzalez, L.C.; Akashi-Takamura, S.; Miyake, K.; Zhang, J.; Lee, W.P.; Muszyński, A.; et al. Noncanonical inflammasome activation by intracellular LPS independent of TLR4. Science 2013, 341, 12461249. [CrossRef]

96. Neff, C.P.; Rhodes, M.E.; Arnolds, K.L.; Collins, C.B.; Donnelly, J.; Nusbacher, N.; Jedlicka, P.; Schneider, J.M.; McCarter, M.D.; Shaffer, M.; et al. Diverse Intestinal Bacteria Contain Putative Zwitterionic Capsular Polysaccharides with Anti-inflammatory Properties. Cell Host Microbe 2016, 20, 535-547. [CrossRef]

97. Erturk-Hasdemir, D.; Oh, S.F.; Okan, N.A.; Stefanetti, G.; Gazzaniga, F.S.; Seeberger, P.H.; Plevy, S.E.; Kasper, D.L. Symbionts exploit complex signaling to educate the immune system. Proc. Natl. Acad. Sci. USA 2019, 116, 26157-26166. [CrossRef]

98. Rutz, S.; Ouyang, W. Regulation of interleukin-10 expression. Adv. Exp. Med. Biol. 2016, 941, 89-116. [CrossRef] [PubMed]

99. Hedblom, G.A.; Reiland, H.A.; Sylte, M.J.; Johnson, T.J.; Baumler, D.J. Segmented filamentous bacteria-Metabolism meets immunity. Front. Microbiol. 2018, 9, 1991. [CrossRef] [PubMed]

100. Beller, A.; Kruglov, A.; Durek, P.; von Goetze, V.; Werner, K.; Heinz, G.A.; Ninnemann, J.; Lehmann, K.; Maier, R.; Hoffmann, U.; et al. Specific microbiota enhances intestinal IgA levels by inducing TGF- $\beta$ in T follicular helper cells of Peyer's patches in mice. Eur. J. Immunol. 2020, 50, 783-794. [CrossRef]

101. McAleer, J.P.; Nguyen, N.L.H.; Chen, K.; Kumar, P.; Ricks, D.M.; Binnie, M.; Armentrout, R.A.; Pociask, D.A.; Hein, A.; Yu, A.; et al. Pulmonary Th17 Antifungal Immunity Is Regulated by the Gut Microbiome. J. Immunol. 2016, 197, 97-107. [CrossRef] [PubMed]

102. Schnupf, P.; Gaboriau-Routhiau, V.; Gros, M.; Friedman, R.; Moya-Nilges, M.; Nigro, G.; Cerf-Bensussan, N.; Sansonetti, P.J. Growth and host interaction of mouse segmented filamentous bacteria in vitro. Nature 2015, 520, 99-103. [CrossRef]

103. Schnupf, P.; Gaboriau-Routhiau, V.; Sansonetti, P.J.; Cerf-Bensussan, N. Segmented filamentous bacteria, Th17 inducers and helpers in a hostile world. Curr. Opin. Microbiol. 2017, 35, 100-109. [CrossRef]

104. Omenetti, S.; Pizarro, T.T. The Treg/Th17 axis: A dynamic balance regulated by the gut microbiome. Front. Immunol. 2015, 6, 639. [CrossRef]

105. Cui, H.; Cai, Y.; Wang, L.; Jia, B.; Li, J.; Zhao, S.; Chu, X.; Lin, J.; Zhang, X.; Bian, Y.; et al. Berberine regulates Treg/Th17 balance to treat ulcerative colitis through modulating the gut microbiota in the colon. Front. Pharmacol. 2018, 9. [CrossRef]

106. Fasching, P.; Stradner, M.; Graninger, W.; Dejaco, C.; Fessler, J. Therapeutic potential of targeting the Th17/Treg axis in autoimmune disorders. Molecules 2017, 22, 134. [CrossRef] [PubMed]

107. Tan, T.G.; Sefik, E.; Geva-Zatorsky, N.; Kua, L.; Naskar, D.; Teng, F.; Pasman, L.; Ortiz-Lopez, A.; Jupp, R.; Wu, H.J.J.; et al Identifying species of symbiont bacteria from the human gut that, alone, can induce intestinal Th17 cells in mice. Proc. Natl. Acad. Sci. USA 2016, 113, E8141-E8150. [CrossRef]

108. Atarashi, K.; Tanoue, T.; Ando, M.; Kamada, N.; Nagano, Y.; Narushima, S.; Suda, W.; Imaoka, A.; Setoyama, H.; Nagamori, T.; et al. Th17 Cell Induction by Adhesion of Microbes to Intestinal Epithelial Cells. Cell 2015, 163, 367-380. [CrossRef] [PubMed]

109. Shibata, N.; Kunisawa, J.; Hosomi, K.; Fujimoto, Y.; Mizote, K.; Kitayama, N.; Shimoyama, A.; Mimuro, H.; Sato, S.; Kishishita, N.; et al. Lymphoid tissue-resident Alcaligenes LPS induces IgA production without excessive inflammatory responses via weak TLR4 agonist activity. Mucosal Immunol. 2018, 11, 693-702. [CrossRef]

110. Van Lier, D.; Geven, C.; Leijte, G.P.; Pickkers, P. Experimental human endotoxemia as a model of systemic inflammation. Biochimie 2019, 159, 99-106. [CrossRef] [PubMed]

111. Hosomi, K.; Shibata, N.; Shimoyama, A.; Uto, T.; Nagatake, T.; Tojima, Y.; Nishino, T.; Takeyama, H.; Fukase, K.; Kiyono, H.; et al. Lymphoid Tissue-Resident Alcaligenes Establish an Intracellular Symbiotic Environment by Creating a Unique Energy Shift in Dendritic Cells. Front. Microbiol. 2020, 11. [CrossRef] [PubMed]

112. Lopetuso, L.R.; Scaldaferri, F.; Petito, V.; Gasbarrini, A. Commensal Clostridia: Leading players in the maintenance of gut homeostasis. Gut Pathog. 2013, 5, 23. [CrossRef]

113. Atarashi, K.; Tanoue, T.; Oshima, K.; Suda, W.; Nagano, Y.; Nishikawa, H.; Fukuda, S.; Saito, T.; Narushima, S.; Hase, K.; et al. Treg induction by a rationally selected mixture of Clostridia strains from the human microbiota. Nature 2013, 500, 232-236. [CrossRef] [PubMed] 
114. Darkoh, C.; Plants-Paris, K.; Bishoff, D.; DuPont, H.L. Clostridium difficile Modulates the Gut Microbiota by Inducing the Production of Indole, an Interkingdom Signaling and Antimicrobial Molecule. mSystems 2019, 4. [CrossRef]

115. Broz, P.; Dixit, V.M. Inflammasomes: Mechanism of assembly, regulation and signaling. Nat. Rev. Immunol. 2016, 16, 407-420. [CrossRef] [PubMed]

116. Zheng, D.; Liwinski, T.; Elinav, E. Interaction between microbiota and immunity in health and disease. Cell Res. 2020, 30, 492-506. [CrossRef]

117. Seo, S.U.; Kamada, N.; Muñoz-Planillo, R.; Kim, Y.G.; Kim, D.; Koizumi, Y.; Hasegawa, M.; Himpsl, S.D.; Browne, H.P.; Lawley, T.D.; et al. Distinct Commensals Induce Interleukin-1 $\beta$ via NLRP3 Inflammasome in Inflammatory Monocytes to Promote Intestinal Inflammation in Response to Injury. Immunity 2015, 42, 744-755. [CrossRef] [PubMed]

118. Gálvez, E.J.C.; Iljazovic, A.; Gronow, A.; Flavell, R.; Strowig, T. Shaping of Intestinal Microbiota in Nlrp6- and Rag2-Deficient Mice Depends on Community Structure. Cell Rep. 2017, 21, 3914-3926. [CrossRef]

119. Elinav, E.; Strowig, T.; Kau, A.L.; Henao-Mejia, J.; Thaiss, C.A.; Booth, C.J.; Peaper, D.R.; Bertin, J.; Eisenbarth, S.C.; Gordon, J.I.; et al. NLRP6 inflammasome regulates colonic microbial ecology and risk for colitis. Cell 2011, 145, 745-757. [CrossRef]

120. Seregin, S.S.; Golovchenko, N.; Schaf, B.; Chen, J.; Pudlo, N.A.; Mitchell, J.; Baxter, N.T.; Zhao, L.; Schloss, P.D.; Martens, E.C.; et al. NLRP6 Protects Il10- / - Mice from Colitis by Limiting Colonization of Akkermansia muciniphila. Cell Rep. 2017, 19, 733-745. [CrossRef]

121. Ottman, N.; Reunanen, J.; Meijerink, M.; Pietilä, T.E.; Kainulainen, V.; Klievink, J.; Huuskonen, L.; Aalvink, S.; Skurnik, M.; Boeren, S.; et al. Pili-like proteins of Akkermansia muciniphila modulate host immune responses and gut barrier function. PLoS ONE 2017, 12, e0173004. [CrossRef] [PubMed]

122. Ansaldo, E.; Slayden, L.C.; Ching, K.L.; Koch, M.A.; Wolf, N.K.; Plichta, D.R.; Brown, E.M.; Graham, D.B.; Xavier, R.J.; Moon, J.J.; et al. Akkermansia muciniphila induces intestinal adaptive immune responses during homeostasis. Science 2019, 364, 1179-1184. [CrossRef]

123. Rossi, O.; Van Berkel, L.A.; Chain, F.; Tanweer Khan, M.; Taverne, N.; Sokol, H.; Duncan, S.H.; Flint, H.J.; Harmsen, H.J.M.; Langella, P.; et al. Faecalibacterium prausnitzii A2-165 has a high capacity to induce IL-10 in human and murine dendritic cells and modulates T cell responses. Sci. Rep. 2016, 6, 18507. [CrossRef]

124. Van den Nieuwboer, M.; van Hemert, S.; Claassen, E.; de Vos, W.M. Lactobacillus plantarum WCFS1 and its host interaction: A dozen years after the genome. Microb. Biotechnol. 2016, 9, 452-465. [CrossRef]

125. Ashraf, R.; Shah, N.P. Immune System Stimulation by Probiotic Microorganisms. Crit. Rev. Food Sci. Nutr. 2014, 54, 938-956. [CrossRef] [PubMed]

126. Sivan, A.; Corrales, L.; Hubert, N.; Williams, J.B.; Aquino-Michaels, K.; Earley, Z.M.; Benyamin, F.W.; Lei, Y.M.; Jabri, B.; Alegre, M.L.; et al. Commensal Bifidobacterium promotes antitumor immunity and facilitates anti-PD-L1 efficacy. Science 2015, 350, 1084-1089. [CrossRef]

127. Sun, S.; Luo, L.; Liang, W.; Yin, Q.; Guo, J.; Rush, A.M.; Lv, Z.; Liang, Q.; Fischbach, M.A.; Sonnenburg, J.L.; et al. Bifidobacterium alters the gut microbiota and modulates the functional metabolism of T regulatory cells in the context of immune checkpoint blockade. Proc. Natl. Acad. Sci. USA 2020, 117, 27509-27515. [CrossRef]

128. Ni, Y.; Yang, X.; Zheng, L.; Wang, Z.; Wu, L.; Jiang, J.; Yang, T.; Ma, L.; Fu, Z. Lactobacillus and Bifidobacterium Improves Physiological Function and Cognitive Ability in Aged Mice by the Regulation of Gut Microbiota. Mol. Nutr. Food Res. 2019, 63. [CrossRef]

129. Sivaprakasam, S.; Bhutia, Y.D.; Yang, S.; Ganapathy, V. Short-chain fatty acid transporters: Role in colonic homeostasis. Compr. Physiol. 2018, 8, 299-314. [CrossRef]

130. Macia, L.; Tan, J.; Vieira, A.T.; Leach, K.; Stanley, D.; Luong, S.; Maruya, M.; Ian McKenzie, C.; Hijikata, A.; Wong, C.; et al. Metabolite-sensing receptors GPR43 and GPR109A facilitate dietary fibre-induced gut homeostasis through regulation of the inflammasome. Nat. Commun. 2015, 6. [CrossRef] [PubMed]

131. Martin-Gallausiaux, C.; Béguet-Crespel, F.; Marinelli, L.; Jamet, A.; Ledue, F.; Blottière, H.M.; Lapaque, N. Butyrate produced by gut commensal bacteria activates TGF-beta1 expression through the transcription factor SP1 in human intestinal epithelial cells. Sci. Rep. 2018, 8. [CrossRef]

132. Corrêa-Oliveira, R.; Fachi, J.L.; Vieira, A.; Sato, F.T.; Vinolo, M.A.R. Regulation of immune cell function by short-chain fatty acids. Clin. Transl. Immunol. 2016, 5, e73. [CrossRef]

133. Kelly, C.J.; Zheng, L.; Campbell, E.L.; Saeedi, B.; Scholz, C.C.; Bayless, A.J.; Wilson, K.E.; Glover, L.E.; Kominsky, D.J.; Magnuson, A.; et al. Crosstalk between microbiota-derived short-chain fatty acids and intestinal epithelial HIF augments tissue barrier function. Cell Host Microbe 2015, 17, 662-671. [CrossRef]

134. Chambers, E.S.; Preston, T.; Frost, G.; Morrison, D.J. Role of Gut Microbiota-Generated Short-Chain Fatty Acids in Metabolic and Cardiovascular Health. Curr. Nutr. Rep. 2018, 7, 198-206. [CrossRef]

135. Gonçalves, P.; Araújo, J.R.; Di Santo, J.P. A cross-talk between microbiota-derived short-chain fatty acids and the host mucosal immune system regulates intestinal homeostasis and inflammatory bowel disease. Inflamm. Bowel Dis. 2018, $24,558-572$. [CrossRef]

136. Sun, M.; Wu, W.; Liu, Z.; Cong, Y. Microbiota metabolite short chain fatty acids, GPCR, and inflammatory bowel diseases. J. Gastroenterol. 2017, 52,1-8. [CrossRef] [PubMed] 
137. Chen, L.; Sun, M.; Wu, W.; Yang, W.; Huang, X.; Xiao, Y.; Ma, C.; Xu, L.; Yao, S.; Liu, Z.; et al. Microbiota Metabolite Butyrate Differentially Regulates Th1 and Th17 Cells' Differentiation and Function in Induction of Colitis. Inflamm. Bowel Dis. 2019, 25, 1450-1461. [CrossRef] [PubMed]

138. Lavoie, S.; Conway, K.L.; Lassen, K.G.; Jijon, H.B.; Pan, H.; Chun, E.; Michaud, M.; Lang, J.K.; Gallini Comeau, C.A.; Dreyfuss, J.M.; et al. The Crohn's disease polymorphism, ATG16L1 T300A, alters the gut microbiota and enhances the local Th1/Th17 response. Elife 2019, 8. [CrossRef] [PubMed]

139. Kim, M.; Qie, Y.; Park, J.; Kim, C.H. Gut Microbial Metabolites Fuel Host Antibody Responses. Cell Host Microbe 2016, $20,202-214$. [CrossRef] [PubMed]

140. Morrison, D.J.; Preston, T. Formation of short chain fatty acids by the gut microbiota and their impact on human metabolism. Gut Microbes 2016, 7, 189-200. [CrossRef]

141. Li, M.; van Esch, B.C.A.M.; Wagenaar, G.T.M.; Garssen, J.; Folkerts, G.; Henricks, P.A.J. Pro- and anti-inflammatory effects of short chain fatty acids on immune and endothelial cells. Eur. J. Pharmacol. 2018, 831, 52-59. [CrossRef]

142. Đanić, M.; Stanimirov, B.; Pavlović, N.; Goločorbin-Kon, S.; Al-Salami, H.; Stankov, K.; Mikov, M. Pharmacological applications of bile acids and their derivatives in the treatment of metabolic syndrome. Front. Pharmacol. 2018, 9, 1382. [CrossRef]

143. Jia, W.; Xie, G.; Jia, W. Bile acid-microbiota crosstalk in gastrointestinal inflammation and carcinogenesis. Nat. Rev. Gastroenterol. Hepatol. 2018, 15, 111-128. [CrossRef] [PubMed]

144. Fiorucci, S.; Biagioli, M.; Zampella, A.; Distrutti, E. Bile acids activated receptors regulate innate immunity. Front. Immunol. 2018, 9, 1853. [CrossRef]

145. Guo, C.; Xie, S.; Chi, Z.; Zhang, J.; Liu, Y.; Zhang, L.; Zheng, M.; Zhang, X.; Xia, D.; Ke, Y.; et al. Bile Acids Control Inflammation and Metabolic Disorder through Inhibition of NLRP3 Inflammasome. Immunity 2016, 45, 802-816. [CrossRef]

146. Levy, M.; Thaiss, C.A.; Zeevi, D.; Dohnalová, L.; Zilberman-Schapira, G.; Mahdi, J.A.; David, E.; Savidor, A.; Korem, T.; Herzig, Y.; et al. Microbiota-Modulated Metabolites Shape the Intestinal Microenvironment by Regulating NLRP6 Inflammasome Signaling. Cell 2015, 163, 1428-1443. [CrossRef] [PubMed]

147. Hang, S.; Paik, D.; Yao, L.; Kim, E.; Jamma, T.; Lu, J.; Ha, S.; Nelson, B.N.; Kelly, S.P.; Wu, L.; et al. Bile acid metabolites control TH17 and Treg cell differentiation. Nature 2019, 576, 143-148. [CrossRef] [PubMed]

148. Song, X.; Sun, X.; Oh, S.F.; Wu, M.; Zhang, Y.; Zheng, W.; Geva-Zatorsky, N.; Jupp, R.; Mathis, D.; Benoist, C.; et al. Microbial bile acid metabolites modulate gut ROR $\gamma+$ regulatory T cell homeostasis. Nature 2020, 577, 410-415. [CrossRef]

149. Pols, T.W.H.; Puchner, T.; Korkmaz, H.I.; Vos, M.; Soeters, M.R.; De Vries, C.J.M. Lithocholic acid controls adaptive immune responses by inhibition of Th1 activation through the Vitamin D receptor. PLoS ONE 2017, 12, e0176715. [CrossRef]

150. Ridlon, J.M.; Kang, D.J.; Hylemon, P.B.; Bajaj, J.S. Bile acids and the gut microbiome. Curr. Opin. Gastroenterol. 2014, 30, 332-338. [CrossRef] [PubMed]

151. Wang, J.; Dong, R.; Zheng, S. Roles of the inflammasome in the gut-liver axis (Review). Mol. Med. Rep. 2019, 19, 3-14. [CrossRef]

152. Chen, M.L.; Takeda, K.; Sundrud, M.S. Emerging roles of bile acids in mucosal immunity and inflammation. Mucosal Immunol. 2019, 12, 851-861. [CrossRef] [PubMed]

153. Schwenger, K.J.; Clermont-Dejean, N.; Allard, J.P. The role of the gut microbiome in chronic liver disease: The clinical evidence revised. JHEP Rep. 2019, 1, 214-226. [CrossRef]

154. Gao, J.; Xu, K.; Liu, H.; Liu, G.; Bai, M.; Peng, C.; Li, T.; Yin, Y. Impact of the gut microbiota on intestinal immunity mediated by tryptophan metabolism. Front. Cell. Infect. Microbiol. 2018, 8, 13. [CrossRef]

155. Hendrikx, T.; Schnabl, B. Indoles: Metabolites produced by intestinal bacteria capable of controlling liver disease manifestation. J. Intern. Med. 2019, 286, 32-40. [CrossRef]

156. Zelante, T.; Iannitti, R.G.; Cunha, C.; DeLuca, A.; Giovannini, G.; Pieraccini, G.; Zecchi, R.; D’Angelo, C.; Massi-Benedetti, C.; Fallarino, F; et al. Tryptophan catabolites from microbiota engage aryl hydrocarbon receptor and balance mucosal reactivity via interleukin-22. Immunity 2013, 39, 372-385. [CrossRef] [PubMed]

157. Mohinta, S.; Kannan, A.K.; Gowda, K.; Amin, S.G.; Perdew, G.H.; August, A. Differential regulation of Th17 and T regulatory cell differentiation by aryl hydrocarbon receptor dependent xenobiotic response element dependent and independent pathways. Toxicol. Sci. 2015, 145, 233-243. [CrossRef] [PubMed]

158. Cervantes-Barragan, L.; Chai, J.N.; Tianero, M.D.; Di Luccia, B.; Ahern, P.P.; Merriman, J.; Cortez, V.S.; Caparon, M.G.; Donia, M.S.; Gilfillan, S.; et al. Lactobacillus reuteri induces gut intraepithelial CD4+CD8 $\alpha \alpha+$ T cells. Science 2017, 357, 806-810. [CrossRef]

159. Gutiérrez-Vázquez, C.; Quintana, F.J. Regulation of the Immune Response by the Aryl Hydrocarbon Receptor. Immunity 2018, 48, 19-33. [CrossRef]

160. Hendrikx, T.; Duan, Y.; Wang, Y.; Oh, J.H.; Alexander, L.M.; Huang, W.; Stärkel, P.; Ho, S.B.; Gao, B.; Fiehn, O.; et al. Bacteria engineered to produce IL-22 in intestine induce expression of REG3G to reduce ethanol-induced liver disease in mice. Gut 2019, 68, 1504-1515. [CrossRef] [PubMed]

161. Clarke, G.; Stilling, R.M.; Kennedy, P.J.; Stanton, C.; Cryan, J.F.; Dinan, T.G. Minireview: Gut microbiota: The neglected endocrine organ. Mol. Endocrinol. 2014, 28, 1221-1238. [CrossRef]

162. Kennedy, P.J.; Cryan, J.F.; Dinan, T.G.; Clarke, G. Kynurenine pathway metabolism and the microbiota-gut-brain axis. Neuropharmacology 2017, 112, 399-412. [CrossRef]

163. Lässiger-Herfurth, A.; Pontarollo, G.; Grill, A.; Reinhardt, C. The gut microbiota in cardiovascular disease and arterial thrombosis. Microorganisms 2019, 7, 691. [CrossRef] 
164. Codella, R.; Luzi, L.; Terruzzi, I. Exercise has the guts: How physical activity may positively modulate gut microbiota in chronic and immune-based diseases. Dig. Liver Dis. 2018, 50, 331-341. [CrossRef]

165. Zheng, D.; Ratiner, K.; Elinav, E. Circadian Influences of Diet on the Microbiome and Immunity. Trends Immunol. 2020, 41, 512-530. [CrossRef]

166. Conlon, M.A.; Bird, A.R. The impact of diet and lifestyle on gut microbiota and human health. Nutrients 2015, 7, 17-44. [CrossRef]

167. Biesalski, H.K. Nutrition meets the microbiome: Micronutrients and the microbiota. Ann. N. Y. Acad. Sci. 2016, 1372, 53-64. [CrossRef]

168. Cordain, L.; Eaton, S.B.; Sebastian, A.; Mann, N.; Lindeberg, S.; Watkins, B.A.; O’Keefe, J.H.; Brand-Miller, J. Origins and evolution of the Western diet: Health implications for the 21st century. Am. J. Clin. Nutr. 2005, 81, 341-354. [CrossRef]

169. Ströhle, A.; Wolters, M.; Hahn, A. Human nutrition in the context of evolutionary medicine. Wien. Klin. Wochenschr. 2009, 121, 173-187. [CrossRef] [PubMed]

170. Burr, A.H.P.; Bhattacharjee, A.; Hand, T.W. Nutritional Modulation of the Microbiome and Immune Response. J. Immunol. 2020, 205, 1479-1487. [CrossRef]

171. Schröder, L.; Kaiser, S.; Flemer, B.; Hamm, J.; Hinrichsen, F.; Bordoni, D.; Rosenstiel, P.; Sommer, F. Nutritional targeting of the microbiome as potential therapy for malnutrition and chronic inflammation. Nutrients 2020, 12, 3032. [CrossRef] [PubMed]

172. Calder, P.C. Immunonutrition. Br. Med. J. 2003, 327, 117-118. [CrossRef] [PubMed]

173. Venter, C.; Eyerich, S.; Sarin, T.; Klatt, K.C. Nutrition and the immune system: A complicated tango. Nutrients 2020, $12,818$. [CrossRef]

174. Birgisdottir, B.E. Nutrition is key to global pandemic resilience. BMJ Nutr. Prev. Health 2020. [CrossRef] [PubMed]

175. Calder, P.C. Nutrition, immunity and COVID-19. BMJ Nutr. Prev. Health 2020, 3, 74-92. [CrossRef] [PubMed]

176. Sharma, L.; Riva, A. Intestinal barrier function in health and disease-Any role of sars-cov-2? Microorganisms 2020, 8, 1744. [CrossRef] [PubMed]

177. Dhar, D.; Mohanty, A. Gut microbiota and Covid-19- possible link and implications. Virus Res. 2020, 285, 198018. [CrossRef]

178. Prescott, S.L. Early Nutrition as a Major Determinant of "Immune Health": Implications for Allergy, Obesity and Other Noncommunicable Diseases. Nestle Nutr. Inst. Workshop Ser. 2016, 85, 1-17. [CrossRef]

179. Zawada, A.; Rychter, A.M.; Ratajczak, A.E.; Lisiecka-Masian, A.; Dobrowolska, A.; Krela-Kaźmierczak, I. Does Gut-Microbiome Interaction Protect against Obesity and Obesity-Associated Metabolic Disorders? Microorganisms 2020, 9, 18. [CrossRef]

180. Fetissov, S.O. Role of the gut microbiota in host appetite control: Bacterial growth to animal feeding behaviour. Nat. Rev. Endocrinol. 2017, 13, 11-25. [CrossRef]

181. Meng, Y.; Li, X.; Zhang, J.; Wang, C.; Lu, F. Effects of Different Diets on Microbiota in The Small Intestine Mucus and Weight Regulation in Rats. Sci. Rep. 2019, 9. [CrossRef] [PubMed]

182. Rohr, M.W.; Narasimhulu, C.A.; Rudeski-Rohr, T.A.; Parthasarathy, S. Negative Effects of a High-Fat Diet on Intestinal Permeability: A Review. Adv. Nutr. 2020, 11, 77-91. [CrossRef]

183. Bifulco, M. Mediterranean diet: The missing link between gut microbiota and inflammatory diseases. Eur. J. Clin. Nutr. 2015, 69, 1078. [CrossRef]

184. Wan, M.L.Y.; Ling, K.H.; El-Nezami, H.; Wang, M.F. Influence of functional food components on gut health. Crit. Rev. Food Sci. Nutr. 2019, 59, 1927-1936. [CrossRef]

185. Serra-Majem, L.; Román-Viñas, B.; Sanchez-Villegas, A.; Guasch-Ferré, M.; Corella, D.; La Vecchia, C. Benefits of the Mediterranean diet: Epidemiological and molecular aspects. Mol. Aspects Med. 2019, 67, 1-55. [CrossRef]

186. Pecora, F.; Persico, F.; Argentiero, A.; Neglia, C.; Esposito, S. The role of micronutrients in support of the immune response against viral infections. Nutrients 2020, 12, 3198. [CrossRef] [PubMed]

187. Barrea, L.; Muscogiuri, G.; Frias-Toral, E.; Laudisio, D.; Pugliese, G.; Castellucci, B.; Garcia-Velasquez, E.; Savastano, S.; Colao, A. Nutrition and immune system: From the Mediterranean diet to dietary supplementary through the microbiota. Crit. Rev. Food Sci. Nutr. 2020, 1-25. [CrossRef]

188. Gombart, A.F.; Pierre, A.; Maggini, S. A review of micronutrients and the immune system-working in harmony to reduce the risk of infection. Nutrients 2020, 12, 236. [CrossRef] [PubMed]

189. Esposito, K.; Maiorino, M.I.; Bellastella, G.; Panagiotakos, D.B.; Giugliano, D. Mediterranean diet for type 2 diabetes: Cardiometabolic benefits. Endocrine 2017, 56, 27-32. [CrossRef]

190. Krznarić, Ž.; Vranešić Bender, D.; Meštrović, T. The Mediterranean diet and its association with selected gut bacteria. Curr. Opin. Clin. Nutr. Metab. Care 2019, 22, 401-406. [CrossRef]

191. Garcia-Mantrana, I.; Selma-Royo, M.; Alcantara, C.; Collado, M.C. Shifts on gut microbiota associated to mediterranean diet adherence and specific dietary intakes on general adult population. Front. Microbiol. 2018, 9. [CrossRef] [PubMed]

192. Merra, G.; Noce, A.; Marrone, G.; Cintoni, M.; Tarsitano, M.G.; Capacci, A.; De Lorenzo, A. Influence of mediterranean diet on human gut microbiota. Nutrients 2021, 13, 7. [CrossRef]

193. Tosti, V.; Bertozzi, B.; Fontana, L. Health Benefits of the Mediterranean Diet: Metabolic and Molecular Mechanisms. J. Gerontol. Ser. A Biol. Sci. Med. Sci. 2018, 73, 318-326. [CrossRef] [PubMed]

194. Mazzocchi, A.; Leone, L.; Agostoni, C.; Pali-Schöll, I. The secrets of the mediterranean diet. Does [only] olive oil matter? Nutrients 2019, 11, 2941. [CrossRef] 
195. Jimenez-Lopez, C.; Carpena, M.; Lourenço-Lopes, C.; Gallardo-Gomez, M.; Lorenzo, J.M.; Barba, F.J.; Prieto, M.A.; Simal-Gandara, J. Bioactive compounds and quality of extra virgin olive oil. Foods 2020, 9, 1014. [CrossRef] [PubMed]

196. Gavahian, M.; Mousavi Khaneghah, A.; Lorenzo, J.M.; Munekata, P.E.S.; Garcia-Mantrana, I.; Collado, M.C.; Meléndez-Martínez, A.J.; Barba, F.J. Health benefits of olive oil and its components: Impacts on gut microbiota antioxidant activities, and prevention of noncommunicable diseases. Trends Food Sci. Technol. 2019, 88, 220-227. [CrossRef]

197. Marcelino, G.; Hiane, P.A.; de Freitas, K.C.; Santana, L.F.; Pott, A.; Donadon, J.R.; de Guimarães, R.C.A. Effects of olive oil and its minor components on cardiovascular diseases, inflammation, and gut microbiota. Nutrients 2019, 11, 1826. [CrossRef]

198. Luisi, M.L.E.; Lucarini, L.; Biffi, B.; Rafanelli, E.; Pietramellara, G.; Durante, M.; Vidali, S.; Provensi, G.; Madiai, S.; Gheri, C.F.; et al. Effect of Mediterranean Diet Enriched in High Quality Extra Virgin Olive Oil on Oxidative Stress, Inflammation and Gut Microbiota in Obese and Normal Weight Adult Subjects. Front. Pharmacol. 2019, 10, 1366. [CrossRef] [PubMed]

199. Farràs, M.; Martinez-Gili, L.; Portune, K.; Arranz, S.; Frost, G.; Tondo, M.; Blanco-Vaca, F. Modulation of the Gut Microbiota by Olive Oil Phenolic Compounds: Implications for Lipid Metabolism, Immune System, and Obesity. Nutrients 2020, 12, 2200. [CrossRef]

200. Cariello, M.; Contursi, A.; Gadaleta, R.M.; Piccinin, E.; De Santis, S.; Piglionica, M.; Spaziante, A.F.; Sabbà, C.; Villani, G.; Moschetta, A. Extra-virgin olive oil from apulian cultivars and intestinal inflammation. Nutrients 2020, 12, 1084. [CrossRef]

201. Piccinin, E.; Cariello, M.; De Santis, S.; Ducheix, S.; Sabbà, C.; Ntambi, J.M.; Moschetta, A. Role of oleic acid in the gut-liver axis: From diet to the regulation of its synthesis via Stearoyl-CoA desaturase 1 (SCD1). Nutrients 2019, 11, 2283. [CrossRef]

202. Wolters, M.; Ahrens, J.; Romaní-Pérez, M.; Watkins, C.; Sanz, Y.; Benítez-Páez, A.; Stanton, C.; Günther, K. Dietary fat, the gut microbiota, and metabolic health-A systematic review conducted within the MyNewGut project. Clin. Nutr. 2019, 38, 2504-2520. [CrossRef]

203. Saini, R.K.; Keum, Y.S. Omega-3 and omega-6 polyunsaturated fatty acids: Dietary sources, metabolism, and significance-A review. Life Sci. 2018, 203, 255-267. [CrossRef]

204. Abbott, S.K.; Else, P.L.; Atkins, T.A.; Hulbert, A.J. Fatty acid composition of membrane bilayers: Importance of diet polyunsaturated fat balance. Biochim. Biophys. Acta Biomembr. 2012, 1818, 1309-1317. [CrossRef] [PubMed]

205. Omega-3 Fatty Acids-Consumer. Available online: https://ods.od.nih.gov/factsheets/Omega3FattyAcids-Consumer/ (accessed on 13 January 2021).

206. Shahidi, F.; Ambigaipalan, P. Omega-3 Polyunsaturated Fatty Acids and Their Health Benefits. Annu. Rev. Food Sci. Technol. 2018, 9, 345-381. [CrossRef] [PubMed]

207. Kawashima, H. Intake of arachidonic acid-containing lipids in adult humans: Dietary surveys and clinical trials. Lipids Health Dis. 2019, 18, 101. [CrossRef] [PubMed]

208. Innes, J.K.; Calder, P.C. Omega-6 fatty acids and inflammation. Prostaglandins Leukot. Essent. Fat. Acids 2018, 132, 41-48. [CrossRef]

209. Dinicolantonio, J.J.; O'Keefe, J.H. Importance of maintaining a low omega-6/omega-3 ratio for reducing inflammation. Open Heart 2018, 5, 946. [CrossRef]

210. Casas, R.; Sacanella, E.; Estruch, R. The Immune Protective Effect of the Mediterranean Diet against Chronic Low-grade Inflammatory Diseases. Endocr. Metab. Immune Disord. Targets 2014, 14, 245-254. [CrossRef] [PubMed]

211. Costantini, L.; Molinari, R.; Farinon, B.; Merendino, N. Impact of omega-3 fatty acids on the gut microbiota. Int. J. Mol. Sci. 2017, 18, 2645. [CrossRef]

212. Druart, C.; Bindels, L.B.; Schmaltz, R.; Neyrinck, A.M.; Cani, P.D.; Walter, J.; Ramer-Tait, A.E.; Delzenne, N.M. Ability of the gut microbiota to produce PUFA-derived bacterial metabolites: Proof of concept in germ-free versus conventionalized mice. Mol. Nutr. Food Res. 2015, 59, 1603-1613. [CrossRef]

213. Miyamoto, J.; Igarashi, M.; Watanabe, K.; Karaki, S.-i.; Mukouyama, H.; Kishino, S.; Li, X.; Ichimura, A.; Irie, J.; Sugimoto, Y.; et al. Gut microbiota confers host resistance to obesity by metabolizing dietary polyunsaturated fatty acids. Nat. Commun. 2019, 10. [CrossRef]

214. Devillard, E.; McIntosh, F.M.; Duncan, S.H.; Wallace, R.J. Metabolism of linoleic acid by human gut bacteria: Different routes for biosynthesis of conjugated linoleic acid. J. Bacteriol. 2007, 189, 2566-2570. [CrossRef]

215. Faria, A.M.C.; Gomes-Santos, A.C.; Gonçalves, J.L.; Moreira, T.G.; Medeiros, S.R.; Dourado, L.P.A.; Cara, D.C. Food components and the immune system: From tonic agents to allergens. Front. Immunol. 2013, 4, 102. [CrossRef]

216. Ren, Q.; Yang, B.; Zhang, H.; Ross, R.P.; Stanton, C.; Chen, H.; Chen, W. C9, t11, c15-CLNA and t9, t11, c15-CLNA from Lactobacillus plantarum ZS2058 Ameliorate Dextran Sodium Sulfate-Induced Colitis in Mice. J. Agric. Food Chem. 2020, 68, 3758-3769. [CrossRef]

217. Koudoufio, M.; Desjardins, Y.; Feldman, F.; Spahis, S.; Delvin, E.; Levy, E. Insight into polyphenol and gut microbiota crosstalk: Are their metabolites the key to understand protective effects against metabolic disorders? Antioxidants 2020, 9, 982. [CrossRef] [PubMed]

218. Man, A.W.C.; Zhou, Y.; Xia, N.; Li, H. Involvement of Gut Microbiota, Microbial Metabolites and Interaction with Polyphenol in Host Immunometabolism. Nutrients 2020, 12, 3054. [CrossRef]

219. Mahajan, R.; Goel, G.; Attri, S. Microbe-bio-chemical insight: Reviewing interactions between dietary polyphenols and gut microbiota. Mini Rev. Med. Chem. 2018, 18, 1253-1264. [CrossRef]

220. Ozdal, T.; Sela, D.A.; Xiao, J.; Boyacioglu, D.; Chen, F.; Capanoglu, E. The reciprocal interactions between polyphenols and gut microbiota and effects on bioaccessibility. Nutrients 2016, 8, 78. [CrossRef] [PubMed] 
221. Singh, A.K.; Cabral, C.; Kumar, R.; Ganguly, R.; Rana, H.K.; Gupta, A.; Lauro, M.R.; Carbone, C.; Reis, F.; Pandey, A.K. Beneficial effects of dietary polyphenols on gut microbiota and strategies to improve delivery efficiency. Nutrients 2019, 11, 2216. [CrossRef] [PubMed]

222. Nakashima, M.; Hisada, M.; Goda, N.; Tenno, T.; Kotake, A.; Inotsume, Y.; Kameoka, I.; Hiroaki, H. Opposing Effect of Naringenin and Quercetin on the Junctional Compartment of MDCK II Cells to Modulate the Tight Junction. Nutrients 2020, $12,3285$. [CrossRef] [PubMed]

223. Westfall, S.; Pasinetti, G.M. The Gut Microbiota Links Dietary Polyphenols with Management of Psychiatric Mood Disorders. Front. Neurosci. 2019, 13, 1196. [CrossRef]

224. Colica, C.; Di Renzo, L.; Trombetta, D.; Smeriglio, A.; Bernardini, S.; Cioccoloni, G.; Costa De Miranda, R.; Gualtieri, P.; Sinibaldi Salimei, P.; De Lorenzo, A. Antioxidant Effects of a Hydroxytyrosol-Based Pharmaceutical Formulation on Body Composition, Metabolic State, and Gene Expression: A Randomized Double-Blinded, Placebo-Controlled Crossover Trial. Oxid. Med. Cell. Longev. 2017, 2017. [CrossRef]

225. Perrone, M.A.; Gualtieri, P.; Gratteri, S.; Ali, W.; Sergi, D.; Muscoli, S.; Cammarano, A.; Bernardini, S.; Di Renzo, L.; Romeo, F. Effects of postprandial hydroxytyrosol and derivates on oxidation of LDL, cardiometabolic state and gene expression: A nutrigenomic approach for cardiovascular prevention. J. Cardiovasc. Med. 2019, 20, 419-426. [CrossRef]

226. Liu, Z.; Wang, N.; Ma, Y.; Wen, D. Hydroxytyrosol improves obesity and insulin resistance by modulating gut microbiota in high-fat diet-induced obese mice. Front. Microbiol. 2019, 10. [CrossRef] [PubMed]

227. Martín-Peláez, S.; Mosele, J.I.; Pizarro, N.; Farràs, M.; de la Torre, R.; Subirana, I.; Pérez-Cano, F.J.; Castañer, O.; Solà, R.; Fernandez-Castillejo, S.; et al. Effect of virgin olive oil and thyme phenolic compounds on blood lipid profile: Implications of human gut microbiota. Eur. J. Nutr. 2017, 56, 119-131. [CrossRef] [PubMed]

228. Bird, J.K.; Raederstorff, D.; Weber, P.; Steinert, R.E. Cardiovascular and antiobesity effects of resveratrol mediated through the gut microbiota. Adv. Nutr. 2017, 8, 839-849. [CrossRef]

229. Chaplin, A.; Carpéné, C.; Mercader, J. Resveratrol, metabolic syndrome, and gut microbiota. Nutrients 2018, 10, 1651. [CrossRef]

230. Swamy, S.M.; Rajasekaran, N.S.; Thannickal, V.J. Nuclear Factor-Erythroid-2-Related Factor 2 in Aging and Lung Fibrosis. Am. J. Pathol. 2016, 186, 1712-1723. [CrossRef]

231. Malaguarnera, L. Influence of Resveratrol on the Immune Response. Nutrients 2019, 11, 946. [CrossRef]

232. Qiao, Y.; Sun, J.; Xia, S.; Tang, X.; Shi, Y.; Le, G. Effects of resveratrol on gut microbiota and fat storage in a mouse model with high-fat-induced obesity. Food Funct. 2014, 5, 1241-1249. [CrossRef]

233. Li, Y.; Yao, J.; Han, C.; Yang, J.; Chaudhry, M.T.; Wang, S.; Liu, H.; Yin, Y. Quercetin, inflammation and immunity. Nutrients 2016, 8, 167. [CrossRef]

234. Endale, M.; Park, S.C.; Kim, S.; Kim, S.H.; Yang, Y.; Cho, J.Y.; Rhee, M.H. Quercetin disrupts tyrosine-phosphorylated phosphatidylinositol 3-kinase and myeloid differentiation factor-88 association, and inhibits MAPK/AP-1 and IKK/NF- $\mathrm{kB}-\mathrm{induced}$ inflammatory mediators production in RAW 264.7 cells. Immunobiology 2013, 218, 1452-1467. [CrossRef] [PubMed]

235. Kobori, M.; Takahashi, Y.; Sakurai, M.; Akimoto, Y.; Tsushida, T.; Oike, H.; Ippoushi, K. Quercetin suppresses immune cell accumulation and improves mitochondrial gene expression in adipose tissue of diet-induced obese mice. Mol. Nutr. Food Res. 2016, 60, 300-312. [CrossRef]

236. Mlcek, J.; Jurikova, T.; Skrovankova, S.; Sochor, J. Quercetin and its anti-allergic immune response. Molecules 2016, 21, 623. [CrossRef]

237. Lin, R.; Piao, M.; Song, Y. Dietary Quercetin Increases Colonic Microbial Diversity and Attenuates Colitis Severity in Citrobacter rodentium-Infected Mice. Front. Microbiol. 2019, 10, 1092. [CrossRef]

238. Zhao, L.; Zhang, Q.; Ma, W.; Tian, F.; Shen, H.; Zhou, M. A combination of quercetin and resveratrol reduces obesity in high-fat diet-fed rats by modulation of gut microbiota. Food Funct. 2017, 8, 4644-4656. [CrossRef]

239. Sonnenburg, E.D.; Sonnenburg, J.L. Starving our microbial self: The deleterious consequences of a diet deficient in microbiotaaccessible carbohydrates. Cell Metab. 2014, 20, 779-786. [CrossRef] [PubMed]

240. Sonnenburg, E.D.; Smits, S.A.; Tikhonov, M.; Higginbottom, S.K.; Wingreen, N.S.; Sonnenburg, J.L. Diet-induced extinctions in the gut microbiota compound over generations. Nature 2016, 529, 212-215. [CrossRef] [PubMed]

241. Seal, C.J.; Brownlee, I.A. Whole-grain foods and chronic disease: Evidence from epidemiological and intervention studies. Proc. Nutr. Soc. 2015, 74, 313-319. [CrossRef] [PubMed]

242. Aleixandre, A.; Miguel, M. Dietary fiber and blood pressure control. Food Funct. 2016, 7, 1864-1871. [CrossRef] [PubMed]

243. Tullio, V.; Gasperi, V.; Catani, M.V.; Savini, I. The impact of whole grain intake on gastrointestinal tumors: A focus on colorectal, gastric and esophageal cancers. Nutrients 2020, 13, 81. [CrossRef] [PubMed]

244. Slavin, J. Fiber and prebiotics: Mechanisms and health benefits. Nutrients 2013, 5, 1417-1435. [CrossRef]

245. McRorie, J.W.; McKeown, N.M. Understanding the Physics of Functional Fibers in the Gastrointestinal Tract: An Evidence-Based Approach to Resolving Enduring Misconceptions about Insoluble and Soluble Fiber. J. Acad. Nutr. Diet. 2017, 117, 251-264. [CrossRef]

246. Weickert, M.O.; Pfeiffer, A.F.H. Impact of dietary fiber consumption on insulin resistance and the prevention of type 2 diabetes. J. Nutr. 2018, 148, 7-12. [CrossRef] [PubMed]

247. Davison, K.M.; Temple, N.J. Cereal fiber, fruit fiber, and type 2 diabetes: Explaining the paradox. J. Diabetes Complicat. 2018, 32, 240-245. [CrossRef] [PubMed] 
248. Gołabek, K.D.; Regulska-Ilow, B. Dietary support in insulin resistance: An overview of current scientific reports. Adv. Clin. Exp. Med. 2019, 28, 1577-1585. [CrossRef]

249. Ghanim, H.; Batra, M.; Abuaysheh, S.; Green, K.; Makdissi, A.; Kuhadiya, N.D.; Chaudhuri, A.; Dandona, P. Antiinflammatory and ROS Suppressive Effects of the Addition of Fiber to a High-Fat High-Calorie Meal. J. Clin. Endocrinol. Metab. 2017, 102, 858-869. [CrossRef]

250. Rebello, C.J.; O’Neil, C.E.; Greenway, F.L. Dietary fiber and satiety: The effects of oats on satiety. Nutr. Rev. 2016, 74, 131-147. [CrossRef]

251. Kim, H.S.; Hong, J.T.; Kim, Y.; Han, S.-B. Stimulatory Effect of $\beta$-glucans on Immune Cells. Immune Netw. 2011, 11, 191. [CrossRef]

252. Jayachandran, M.; Chen, J.; Chung, S.S.M.; Xu, B. A critical review on the impacts of $\beta$-glucans on gut microbiota and human health. J. Nutr. Biochem. 2018, 61, 101-110. [CrossRef] [PubMed]

253. Ciecierska, A.; Drywień, M.E.; Hamulka, J.; Sadkowski, T. Nutraceutical functions of beta-glucans in human nutrition. Rocz. Panstw. Zakl. Hig. 2019, 70, 315-324.

254. Dehghan, P.; Gargari, B.P.; Jafar-Abadi, M.A.; Aliasgharzadeh, A. Inulin controls inflammation and metabolic endotoxemia in women with type 2 diabetes mellitus: A randomized-controlled clinical trial. Int. J. Food Sci. Nutr. 2014, 65, 117-123. [CrossRef]

255. Nicola, W.G.; Girgiss, M.W.; Ezz El-Arab, A.M.; Habib, D.F.; Elnemr, M.E.; Ahmed, N.M.; Youness, E.R. Role of inulin in the protection and management of metabolic inflammation in humans. Biomed. Pharmacol. J. 2018, 11, 1083-1090. [CrossRef]

256. Liu, F.; Li, P.; Chen, M.; Luo, Y.; Prabhakar, M.; Zheng, H.; He, Y.; Qi, Q.; Long, H.; Zhang, Y.; et al. Fructooligosaccharide (FOS) and Galactooligosaccharide (GOS) Increase Bifidobacterium but Reduce Butyrate Producing Bacteria with Adverse Glycemic Metabolism in healthy young population. Sci. Rep. 2017, 7. [CrossRef]

257. Holscher, H.D. Dietary fiber and prebiotics and the gastrointestinal microbiota. Gut Microbes 2017, 8, 172-184. [CrossRef] [PubMed]

258. Fang, Q.; Hu, J.; Nie, Q.; Nie, S. Effects of polysaccharides on glycometabolism based on gut microbiota alteration. Trends Food Sci. Technol. 2019, 92, 65-70. [CrossRef]

259. Tang, C.; Ding, R.; Sun, J.; Liu, J.; Kan, J.; Jin, C. The impacts of natural polysaccharides on intestinal microbiota and immune responses-a review. Food Funct. 2019, 10, 2290-2312. [CrossRef] [PubMed]

260. Zhang, T.; Yang, Y.; Liang, Y.; Jiao, X.; Zhao, C. Beneficial effect of intestinal fermentation of natural polysaccharides. Nutrients 2018, 10, 1055. [CrossRef]

261. Putnam, E.E.; Goodman, A.L. B vitamin acquisition by gut commensal bacteria. PLoS Pathog. 2020, 16, e1008208. [CrossRef] [PubMed]

262. Mora, J.R.; Iwata, M.; Von Andrian, U.H. Vitamin effects on the immune system: Vitamins A and D take centre stage. Nat. Rev. Immunol. 2008, 8, 685-698. [CrossRef]

263. Cantorna, M.T.; Snyder, L.; Arora, J. Vitamin A and vitamin D regulate the microbial complexity, barrier function, and the mucosal immune responses to ensure intestinal homeostasis. Crit. Rev. Biochem. Mol. Biol. 2019, 54, 184-192. [CrossRef]

264. Zhang, Y.; Wu, S.; Sun, J. Vitamin D, vitamin D receptor and tissue barriers. Tissue Barriers 2013, 1, e23118. [CrossRef]

265. De Medeiros, P.H.Q.S.; Pinto, D.V.; de Almeida, J.Z.; Rêgo, J.M.C.; Rodrigues, F.A.P.; Lima, A.Â.M.; Bolick, D.T.; Guerrant, R.L.; Oriá, R.B. Modulation of intestinal immune and barrier functions by vitamin A: Implications for current understanding of malnutrition and enteric infections in children. Nutrients 2018, 10, 1128. [CrossRef] [PubMed]

266. Hibberd, M.C.; Wu, M.; Rodionov, D.A.; Li, X.; Cheng, J.; Griffin, N.W.; Barratt, M.J.; Giannone, R.J.; Hettich, R.L.; Osterman, A.L.; et al. The effects of micronutrient deficiencies on bacterial species from the human gut microbiota. Sci. Transl. Med. 2017, 9. [CrossRef]

267. Wu, W.; Sun, M.; Chen, F.; Cao, A.T.; Liu, H.; Zhao, Y.; Huang, X.; Xiao, Y.; Yao, S.; Zhao, Q.; et al. Microbiota metabolite short-chain fatty acid acetate promotes intestinal IgA response to microbiota which is mediated by GPR43. Mucosal Immunol. 2017, 10, 946-956. [CrossRef] [PubMed]

268. Tan, J.; McKenzie, C.; Vuillermin, P.J.; Goverse, G.; Vinuesa, C.G.; Mebius, R.E.; Macia, L.; Mackay, C.R. Dietary Fiber and Bacterial SCFA Enhance Oral Tolerance and Protect against Food Allergy through Diverse Cellular Pathways. Cell Rep. 2016, 15, 2809-2824. [CrossRef] [PubMed]

269. Aitoro, R.; Paparo, L.; Amoroso, A.; Di Costanzo, M.; Cosenza, L.; Granata, V.; Di Scala, C.; Nocerino, R.; Trinchese, G.; Montella, M.; et al. Gut Microbiota as a Target for Preventive and Therapeutic Intervention against Food Allergy. Nutrients 2017, 9, 672. [CrossRef]

270. Czarnewski, P.; Das, S.; Parigi, S.M.; Villablanca, E.J. Retinoic acid and its role in modulating intestinal innate immunity. Nutrients 2017, 9, 68. [CrossRef]

271. Haase, S.; Haghikia, A.; Wilck, N.; Müller, D.N.; Linker, R.A. Impacts of microbiome metabolites on immune regulation and autoimmunity. Immunology 2018, 154, 230-238. [CrossRef]

272. Aranow, C. Correspondence: Cynthia Aranow 350 Community Drive Manhasset, NY 11030. J. Investig. Med. 2011, 59, 881-886. [CrossRef] [PubMed]

273. Ryz, N.R.; Lochner, A.; Bhullar, K.; Ma, C.; Huang, T.; Bhinder, G.; Bosman, E.; Wu, X.; Innis, S.M.; Jacobson, K.; et al. Dietary vitamin D3 deficiency alters intestinal mucosal defense and increases susceptibility to Citrobacter rodentium-induced colitis. Am. J. Physiol. Gastrointest. Liver Physiol. 2015, 309, G730-G742. [CrossRef] 
274. Akimbekov, N.S.; Digel, I.; Sherelkhan, D.K.; Lutfor, A.B.; Razzaque, M.S. Vitamin d and the host-gut microbiome: A brief overview. Acta Histochem. Cytochem. 2020, 53, 33-42. [CrossRef]

275. Su, D.; Nie, Y.; Zhu, A.; Chen, Z.; Wu, P.; Zhang, L.; Luo, M.; Sun, Q.; Cai, L.; Lai, Y.; et al. Vitamin D signaling through induction of paneth cell defensins maintains gut microbiota and improves metabolic disorders and hepatic steatosis in animal models. Front. Physiol. 2016, 7. [CrossRef]

276. Targher, G.; Scorletti, E.; Mantovani, A.; Byrne, C.D. Nonalcoholic fatty liver disease and reduced serum vitamin D3 levels. Metab. Syndr. Relat. Disord. 2013, 11, 217-228. [CrossRef]

277. Nelson, J.E.; Roth, C.L.; Wilson, L.A.; Yates, K.P.; Aouizerat, B.; Morgan-Stevenson, V.; Whalen, E.; Hoofnagle, A.; Mason, M.; Gersuk, V.; et al. Vitamin D deficiency is associated with increased risk of non-alcoholic steatohepatitis in adults with non-alcoholic fatty liver disease: Possible role for MAPK and NF-кB? Am. J. Gastroenterol. 2016, 111, 852-863. [CrossRef]

278. Ströhle, A.; Hahn, A. Vitamin C und immunfunktion. Med. Monatsschr. Pharm. 2009, 32, 49-54. [PubMed]

279. Carr, A.C.; Maggini, S. Vitamin C and immune function. Nutrients 2017, 9, 1211. [CrossRef] [PubMed]

280. Ikeda, S.; Takahashi, S.; Suzuki, N.; Hanzawa, F.; Horio, F.; Oda, H. Gut microbiota is not involved in the induction of acute phase protein expression caused by vitamin C deficiency. J. Nutr. Sci. Vitaminol. 2020, 66, 19-23. [CrossRef] [PubMed]

281. Traber, M.G.; Atkinson, J. Vitamin E, antioxidant and nothing more. Free Radic. Biol. Med. 2007, 43, 4-15. [CrossRef]

282. Xu, C.; Sun, R.; Qiao, X.; Xu, C.; Shang, X.; Niu, W.; Chao, Y. Effect of Vitamin e supplementation on intestinal barrier function in rats exposed to high altitude hypoxia environment. Korean J. Physiol. Pharmacol. 2014, 18, 313-320. [CrossRef]

283. Van Dam, B.; Van Hinsbergh, V.W.M.; Stehouwer, C.D.A.; Versteilen, A.; Dekker, H.; Buytenhek, R.; Princen, H.M.; Schalkwijk, C.G. Vitamin E inhibits lipid peroxidation-induced adhesion molecule expression in endothelial cells and decreases soluble cell adhesion molecules in healthy subjects. Cardiovasc. Res. 2003, 57, 563-571. [CrossRef]

284. Abdala-Valencia, H.; Berdnikovs, S.; Cook-Mills, J.M. Vitamin E Isoforms Differentially Regulate Intercellular Adhesion Molecule1 Activation of PKC $\alpha$ in Human Microvascular Endothelial Cells. PLoS ONE 2012, 7, e41054. [CrossRef]

285. Lewis, E.D.; Meydani, S.N.; Wu, D. Regulatory role of vitamin E in the immune system and inflammation. IUBMB Life 2019, 71, 487-494. [CrossRef] [PubMed]

286. Choi, Y.; Lee, S.; Kim, S.; Lee, J.; Ha, J.; Oh, H.; Lee, Y.; Kim, Y.; Yoon, Y. Vitamin E ( $\alpha$-tocopherol) consumption influences gut microbiota composition. Int. J. Food Sci. Nutr. 2020, 71, 221-225. [CrossRef] [PubMed]

287. Rodionov, D.A.; Arzamasov, A.A.; Khoroshkin, M.S.; Iablokov, S.N.; Leyn, S.A.; Peterson, S.N.; Novichkov, P.S.; Osterman, A.L. Micronutrient Requirements and Sharing Capabilities of the Human Gut Microbiome. Front. Microbiol. 2019, 10, 1316. [CrossRef]

288. Yoshii, K.; Hosomi, K.; Sawane, K.; Kunisawa, J. Metabolism of dietary and microbial vitamin b family in the regulation of host immunity. Front. Nutr. 2019, 6, 48. [CrossRef]

289. Soto-Martin, E.C.; Warnke, I.; Farquharson, F.M.; Christodoulou, M.; Horgan, G.; Derrien, M.; Faurie, J.M.; Flint, H.J.; Duncan, S.H.; Louis, P. Vitamin biosynthesis by human gut butyrate-producing bacteria and cross-feeding in synthetic microbial communities. MBio 2020, 11, 1-18. [CrossRef] [PubMed]

290. Mikkelsen, K.; Apostolopoulos, V. B Vitamins and ageing. Subcell Biochem. 2018, 90, 451-470. [CrossRef]

291. Porter, K.; Hoey, L.; Hughes, C.F.; Ward, M.; McNulty, H. Causes, consequences and public health implications of low B-vitamin status in ageing. Nutrients 2016, 8, 725. [CrossRef] [PubMed]

292. Spinas, E.; Saggini, A.; Kritas, S.K.; Cerulli, G.; Caraffa, A.; Antinolfi, P.; Pantalone, A.; Frydas, A.; Tei, M.; Speziali, A.; et al. Crosstalk between vitamin B and immunity. J. Biol. Regul. Homeost. Agents 2015, 29, 283-288.

293. Suwannasom, N.; Kao, I.; Pruß, A.; Georgieva, R.; Bäumler, H. Riboflavin: The health benefits of a forgotten natural vitamin. Int. J. Mol. Sci. 2020, 21, 950. [CrossRef]

294. Von Martels, J.Z.H.; Bourgonje, A.R.; Klaassen, M.A.Y.; Alkhalifah, H.A.A.; Sadaghian Sadabad, M.; Vich Vila, A.; Gacesa, R.; Gabriëls, R.Y.; Steinert, R.E.; Jansen, B.H.; et al. Riboflavin Supplementation in Patients with Crohn's Disease [the RISE-UP study]. J. Crohn. Colitis 2020, 14, 595-607. [CrossRef] [PubMed]

295. Huang, H.; Koelle, P.; Fendler, M.; Schroettle, A.; Czihal, M.; Hoffmann, U.; Kuhlencordt, P.J. Niacin reverses migratory macrophage foam cell arrest mediated by oxLDL in vitro. PLoS ONE 2014, 9, e0114643. [CrossRef]

296. Tavintharan, S.; Woon, K.; Pek, L.T.; Jauhar, N.; Dong, X.; Lim, S.C.; Sum, C.F. Niacin results in reduced monocyte adhesion in patients with type 2 diabetes mellitus. Atherosclerosis 2011, 215, 176-179. [CrossRef]

297. Montserrat-de la Paz, S.; Naranjo, M.C.; Lopez, S.; Abia, R.; Muriana, F.J.G.; Bermudez, B. Niacin and its metabolites as master regulators of macrophage activation. J. Nutr. Biochem. 2017, 39, 40-47. [CrossRef]

298. Wakade, C.; Giri, B.; Malik, A.; Khodadadi, H.; Morgan, J.C.; Chong, R.K.; Baban, B. Niacin modulates macrophage polarization in Parkinson's disease. J. Neuroimmunol. 2018, 320, 76-79. [CrossRef]

299. Karunaratne, T.B.; Okereke, C.; Seamon, M.; Purohit, S.; Wakade, C.; Sharma, A. Niacin and butyrate: Nutraceuticals targeting dysbiosis and intestinal permeability in parkinson's disease. Nutrients 2021, 13, 28.

300. Li, L.; Feng, L.; Jiang, W.D.; Jiang, J.; Wu, P.; Kuang, S.Y.; Tang, L.; Tang, W.N.; Zhang, Y.A.; Zhou, X.Q.; et al. Dietary pantothenic acid deficiency and excess depress the growth, intestinal mucosal immune and physical functions by regulating NF- $\mathrm{KB}$, TOR, Nrf2 and MLCK signaling pathways in grass carp (Ctenopharyngodon idella). Fish. Shellfish Immunol. 2015, 45, 399-413. [CrossRef]

301. Gominak, S.C. Vitamin D deficiency changes the intestinal microbiome reducing B vitamin production in the gut. The resulting lack of pantothenic acid adversely affects the immune system, producing a "pro-inflammatory" state associated with atherosclerosis and autoimmunity. Med. Hypotheses 2016, 94, 103-107. [CrossRef] 
302. Ueland, P.M.; McCann, A.; Midttun, Ø.; Ulvik, A. Inflammation, vitamin B6 and related pathways. Mol. Aspects Med. 2017, 53, 10-27. [CrossRef]

303. Qian, B.; Shen, S.; Zhang, J.; Jing, P. Effects of Vitamin B6 Deficiency on the Composition and Functional Potential of T Cell Populations. J. Immunol. Res. 2017, 2017. [CrossRef]

304. Bird, R.P. The Emerging Role of Vitamin B6 in Inflammation and Carcinogenesis. Adv Food Nutr Res. 2018, 83, 151-194. [CrossRef]

305. Kuroishi, T. Regulation of immunological and inflammatory functions by biotin. Can. J. Physiol. Pharmacol. 2015, 93, 1091-1096. [CrossRef] [PubMed]

306. Agrawal, S.; Agrawal, A.; Said, H.M. Biotin deficiency enhances the inflammatory response of human dendritic cells. Am. J. Physiol. Cell Physiol. 2016, 311, C386-C391. [CrossRef]

307. Elahi, A.; Sabui, S.; Narasappa, N.N.; Agrawal, S.; Lambrecht, N.W.; Agrawal, A.; Said, H.M. Biotin Deficiency Induces Th1- and Th17-Mediated Proinflammatory Responses in Human CD4 + T Lymphocytes via Activation of the mTOR Signaling Pathway. J. Immunol. 2018, 200, 2563-2570. [CrossRef]

308. Zheng, Y.; Cantley, L.C. Toward a better understanding of folate metabolism in health and disease. J. Exp. Med. 2019, 216, 253-266. [CrossRef]

309. Kunisawa, J.; Kiyono, H. Vitamin-mediated regulation of intestinal immunity. Front. Immunol. 2013, 4, 189. [CrossRef]

310. Park, S.; Kang, S.; Sol Kim, D. Folate and vitamin B-12 deficiencies additively impaired memory function and disturbed the gut microbiota in amyloid-ß infused rats. Int. J. Vitam. Nutr. Res. 2020. [CrossRef]

311. Zhang, J.; Cai, D.; Yang, M.; Hao, Y.; Zhu, Y.; Chen, Z.; Aziz, T.; Sarwar, A.; Yang, Z. Screening of folate-producing lactic acid bacteria and modulatory effects of folate-biofortified yogurt on gut dysbacteriosis of folate-deficient rats. Food Funct. 2020, 11, 6308-6318. [CrossRef]

312. Van de Lagemaat, E.E.; de Groot, L.C.P.G.M.; van den Heuvel, E.G.H.M. Vitamin B 12 in relation to oxidative stress: A systematic review. Nutrients 2019, 11, 482. [CrossRef] [PubMed]

313. Boran, P.; Baris, H.E.; Kepenekli, E.; Erzik, C.; Soysal, A.; Dinh, D.M. The impact of vitamin B12 deficiency on infant gut microbiota. Eur. J. Pediatr. 2020, 179, 385-393. [CrossRef]

314. Degnan, P.H.; Taga, M.E.; Goodman, A.L. Vitamin B12 as a modulator of gut microbial ecology. Cell Metab. 2014, 20 , 769-778. [CrossRef]

315. Rowley, C.A.; Kendall, M.M. To B12 or not to B12: Five questions on the role of cobalamin in host-microbial interactions. PLoS Pathog. 2019, 15, e1007479. [CrossRef]

316. Guzmán, D.C.; Brizuela, N.O.; Herrera, M.O.; Peraza, A.V.; Juárez-Olguín, H.; Mejía, G.B. Insulin plus zinc induces a favorable biochemical response effects on oxidative damage and dopamine levels in rat brain. Int. J. Biol. Macromol. 2019, 132, $230-235$. [CrossRef] [PubMed]

317. Wang, C.; Zhang, R.; Wei, X.; Lv, M.; Jiang, Z. Metalloimmunology: The metal ion-controlled immunity. Adv. Immunol. 2020, 145, 187-241. [CrossRef] [PubMed]

318. Read, S.A.; Obeid, S.; Ahlenstiel, C.; Ahlenstiel, G. The Role of Zinc in Antiviral Immunity. Adv. Nutr. 2019, 10, 696-710. [CrossRef]

319. Wessels, I.; Maywald, M.; Rink, L. Zinc as a gatekeeper of immune function. Nutrients 2017, 9, 1286. [CrossRef]

320. Hojyo, S.; Fukada, T. Roles of Zinc Signaling in the Immune System. J. Immunol. Res. 2016, 2016. [CrossRef]

321. Maares, M.; Haase, H. Zinc and immunity: An essential interrelation. Arch. Biochem. Biophys. 2016, 611, 58-65. [CrossRef]

322. Foligné, B.; George, F.; Standaert, A.; Garat, A.; Poiret, S.; Peucelle, V.; Ferreira, S.; Sobry, H.; Muharram, G.; Lucau-Danila, A.; et al. High-dose dietary supplementation with zinc prevents gut inflammation: Investigation of the role of metallothioneins and beyond by transcriptomic and metagenomic studies. FASEB J. 2020, 34, 12615-12633. [CrossRef]

323. Usama, U.; Jaffar Khan, M.; Fatima, S.; Fatima, S. Role of Zinc in Shaping the Gut Microbiome; Proposed Mechanisms and Evidence from the Literature. J. Gastrointest. Dig. Syst. 2018, 8, 1-4. [CrossRef]

324. Cherayil, B.J.; Ellenbogen, S.; Shanmugam, N.N. Iron and intestinal immunity. Curr. Opin. Gastroenterol. 2011, $27,523-528$. [CrossRef]

325. Chieppa, M.; Giannelli, G. Immune Cells and Microbiota Response to Iron Starvation. Front. Med. 2018, 5, 109. [CrossRef]

326. Elmadfa, I.; Meyer, A.L. The Role of the Status of Selected Micronutrients in Shaping the Immune Function. Endocr. Metab. Immune Disord. Drug Targets 2019, 19, 1100-1115. [CrossRef]

327. Yilmaz, B.; Li, H. Gut microbiota and iron: The crucial actors in health and disease. Pharmaceuticals 2018, 11, 98. [CrossRef]

328. Parmanand, B.A.; Kellingray, L.; Le Gall, G.; Basit, A.W.; Fairweather-Tait, S.; Narbad, A. A decrease in iron availability to human gut microbiome reduces the growth of potentially pathogenic gut bacteria; an in vitro colonic fermentation study. J. Nutr. Biochem. 2019, 67, 20-27. [CrossRef]

329. Skrypnik, K.; Suliburska, J. Association between the gut microbiota and mineral metabolism. J. Sci. Food Agric. 2018, 98, 2449-2460. [CrossRef]

330. Avery, J.C.; Hoffmann, P.R. Selenium, selenoproteins, and immunity. Nutrients 2018, 10, 1203. [CrossRef]

331. Hoffmann, P.R. Mechanisms by which selenium influences immune responses. Arch. Immunol. Ther. Exp. 2007, 55, 289-297. [CrossRef]

332. Hoffmann, P.R.; Berry, M.J. The influence of selenium on immune responses. Mol. Nutr. Food Res. 2008, 52, 1273-1280. [CrossRef] 
333. Kasaikina, M.V.; Kravtsova, M.A.; Lee, B.C.; Seravalli, J.; Peterson, D.A.; Walter, J.; Legge, R.; Benson, A.K.; Hatfield, D.L.; Gladyshev, V.N. Dietary selenium affects host selenoproteome expression by influencing the gut microbiota. FASEB J. 2011, 25, 2492-2499. [CrossRef]

334. Kopp, W. How western diet and lifestyle drive the pandemic of obesity and civilization diseases. Diabetes Metab. Syndr. Obes. Targets Ther. 2019, 12, 2221-2236. [CrossRef]

335. Christ, A.; Lauterbach, M.; Latz, E. Western Diet and the Immune System: An Inflammatory Connection. Immunity 2019, 51, 794-811. [CrossRef]

336. Statovci, D.; Aguilera, M.; MacSharry, J.; Melgar, S. The impact of western diet and nutrients on the microbiota and immune response at mucosal interfaces. Front. Immunol. 2017, 8, 838. [CrossRef]

337. Aguilera, J.M. The food matrix: Implications in processing, nutrition and health. Crit. Rev. Food Sci. Nutr. 2019, 59, 3612-3629. [CrossRef]

338. Shively, C.A.; Appt, S.E.; Vitolins, M.Z.; Uberseder, B.; Michalson, K.T.; Silverstein-Metzler, M.G.; Register, T.C. Mediterranean versus Western Diet Effects on Caloric Intake, Obesity, Metabolism, and Hepatosteatosis in Nonhuman Primates. Obesity 2019, 27, 777-784. [CrossRef] [PubMed]

339. Monteiro, C.A.; Cannon, G.; Moubarac, J.C.; Levy, R.B.; Louzada, M.L.C.; Jaime, P.C. The un Decade of Nutrition, the NOVA food classification and the trouble with ultra-processing. Public Health Nutr. 2018, 21, 5-17. [CrossRef] [PubMed]

340. Srour, B.; Fezeu, L.K.; Kesse-Guyot, E.; Allès, B.; Méjean, C.; Andrianasolo, R.M.; Chazelas, E.; Deschasaux, M.; Hercberg, S.; Galan, P.; et al. Ultra-processed food intake and risk of cardiovascular disease: Prospective cohort study (NutriNet-Santé). BMJ 2019, 365. [CrossRef] [PubMed]

341. Fiolet, T.; Srour, B.; Sellem, L.; Kesse-Guyot, E.; Allès, B.; Méjean, C.; Deschasaux, M.; Fassier, P.; Latino-Martel, P.; Beslay, M.; et al. Consumption of ultra-processed foods and cancer risk: Results from NutriNet-Santé prospective cohort. BMJ $2018,360$. [CrossRef]

342. Monteiro, C.A.; Moubarac, J.C.; Levy, R.B.; Canella, D.S.; Da Costa Louzada, M.L.; Cannon, G. Household availability of ultra-processed foods and obesity in nineteen European countries. Public Health Nutr. 2018, 21, 18-26. [CrossRef]

343. Blanco-Rojo, R.; Sandoval-Insausti, H.; López-Garcia, E.; Graciani, A.; Ordovás, J.M.; Banegas, J.R.; Rodríguez-Artalejo, F.; Guallar-Castillón, P. Consumption of Ultra-Processed Foods and Mortality: A National Prospective Cohort in Spain. Mayo Clin. Proc. 2019, 94, 2178-2188. [CrossRef]

344. Monteiro, C.A.; Cannon, G.; Levy, R.B.; Moubarac, J.C.; Louzada, M.L.C.; Rauber, F.; Khandpur, N.; Cediel, G.; Neri, D.; Martinez-Steele, E.; et al. Ultra-processed foods: What they are and how to identify them. Public Health Nutr. 2019, 22, 936-941. [CrossRef]

345. Martínez Steele, E.; Popkin, B.M.; Swinburn, B.; Monteiro, C.A. The share of ultra-processed foods and the overall nutritional quality of diets in the US: Evidence from a nationally representative cross-sectional study. Popul. Health Metr. 2017, 15. [CrossRef]

346. Khandpur, N.; Neri, D.A.; Monteiro, C.; Mazur, A.; Frelut, M.L.; Boyland, E.; Weghuber, D.; Thivel, D. Ultra-Processed Food Consumption among the Paediatric Population: An Overview and Call to Action from the European Childhood Obesity Group. Ann. Nutr. Metab. 2020, 76, 109-113. [CrossRef]

347. Mallarino, C.; Gómez, L.F.; González-Zapata, L.; Cadena, Y.; Parra, D.C. Advertising of ultra-processed foods and beverages: Children as a vulnerable population. Rev. Saude Publica 2013, 47, 1006-1010. [CrossRef]

348. Crittenden, A.N.; Schnorr, S.L. Current views on hunter-gatherer nutrition and the evolution of the human diet. Am. J. Phys. Anthropol. 2017, 162, 84-109. [CrossRef] [PubMed]

349. Requena, T.; Martínez-Cuesta, M.C.; Peláez, C. Diet and microbiota linked in health and disease. Food Funct. 2018, 9, 688-704. [CrossRef] [PubMed]

350. Paglia, L. The sweet danger of added sugars. Eur. J. Paediatr. Dent. 2019, 20, 89.

351. Reis, D.J.; Ilardi, S.S.; Namekata, M.S.; Wing, E.K.; Fowler, C.H. The depressogenic potential of added dietary sugars. Med. Hypotheses 2020, 134. [CrossRef] [PubMed]

352. DiNicolantonio, J.J.; O’Keefe, J.H.; Wilson, W.L. Sugar addiction: Is it real? A narrative review. Br. J. Sports Med. 2018, 52, 910-913. [CrossRef] [PubMed]

353. Di Nicolantonio, J.J.; Mehta, V.; Onkaramurthy, N.; O’Keefe, J.H. Fructose-induced inflammation and increased cortisol: A new mechanism for how sugar induces visceral adiposity. Prog. Cardiovasc. Dis. 2018, 61, 3-9. [CrossRef] [PubMed]

354. Ramne, S.; Brunkwall, L.; Ericson, U.; Gray, N.; Kuhnle, G.G.C.; Nilsson, P.M.; Orho-Melander, M.; Sonestedt, E. Gut microbiota composition in relation to intake of added sugar, sugar-sweetened beverages and artificially sweetened beverages in the Malmö Offspring Study. Eur. J. Nutr. 2020. [CrossRef]

355. Jensen, T.; Abdelmalek, M.F.; Sullivan, S.; Nadeau, K.J.; Green, M.; Roncal, C.; Nakagawa, T.; Kuwabara, M.; Sato, Y.; Kang, D.H.; et al. Fructose and sugar: A major mediator of non-alcoholic fatty liver disease. J. Hepatol. 2018, 68, 1063-1075. [CrossRef]

356. Vanegas, S.M.; Meydani, M.; Barnett, J.B.; Goldin, B.; Kane, A.; Rasmussen, H.; Brown, C.; Vangay, P.; Knights, D.; Jonnalagadda, S.; et al. Substituting whole grains for refined grains in a 6-wk randomized trial has a modest effect on gut microbiota and immune and inflammatory markers of healthy adults. Am. J. Clin. Nutr. 2017, 105, 635-650. [CrossRef] [PubMed]

357. Munch Roager, H.; Vogt, J.K.; Kristensen, M.; Hansen, L.B.S.; Ibrügger, S.; Maerkedahl, R.B.; Bahl, M.I.; Lind, M.V.; Nielsen, R.L.; Frøkiaer, H.; et al. Whole grain-rich diet reduces body weight and systemic low-grade inflammation without inducing major changes of the gut microbiome: A randomised cross-over trial. Gut 2019, 68, 83-93. [CrossRef] [PubMed] 
358. Gaesser, G.A. Perspective: Refined Grains and Health: Genuine Risk, or Guilt by Association? Adv. Nutr. 2019, 10, 361-371. [CrossRef]

359. Guo, X.; Li, J.; Tang, R.; Zhang, G.; Zeng, H.; Wood, R.J.; Liu, Z. High Fat Diet Alters Gut Microbiota and the Expression of Paneth Cell-Antimicrobial Peptides Preceding Changes of Circulating Inflammatory Cytokines. Mediators Inflamm. 2017, 2017. [CrossRef]

360. Araújo, J.R.; Tomas, J.; Brenner, C.; Sansonetti, P.J. Impact of high-fat diet on the intestinal microbiota and small intestinal physiology before and after the onset of obesity. Biochimie 2017, 141, 97-106. [CrossRef] [PubMed]

361. Gershuni, V.M. Saturated Fat: Part of a Healthy Diet. Curr. Nutr. Rep. 2018, 7, 85-96. [CrossRef]

362. Cornwell, B.; Villamor, E.; Mora-Plazas, M.; Marin, C.; Monteiro, C.A.; Baylin, A. Processed and ultra-processed foods are associated with lower-quality nutrient profiles in children from Colombia. Public Health Nutr. 2018, 21, 142-147. [CrossRef]

363. Gómez-Cortés, P.; de la Fuente, M.Á.; Juárez, M. Trans fatty acids and conjugated linoleic acid in food: Origin and biological properties. Nutr. Hosp. 2019, 36, 479-486. [CrossRef]

364. Murphy, E.A.; Velazquez, K.T.; Herbert, K.M. Influence of high-fat diet on gut microbiota: A driving force for chronic disease risk. Curr. Opin. Clin. Nutr. Metab. Care 2015, 18, 515-520. [CrossRef]

365. Ye, L.; Mueller, O.; Bagwell, J.; Bagnat, M.; Liddle, R.A.; Rawls, J.F. High fat diet induces microbiota-dependent silencing of enteroendocrine cells. Elife 2019, 8. [CrossRef]

366. Cândido, T.L.N.; Bressan, J.; de Alfenas, R.C.G. Dysbiosis and metabolic endotoxemia induced by high-fat diet. Nutr. Hosp. 2018, 35, 1432-1440. [CrossRef]

367. Lin, H.; An, Y.; Tang, H.; Wang, Y. Alterations of Bile Acids and Gut Microbiota in Obesity Induced by High Fat Diet in Rat Model. J. Agric. Food Chem. 2019, 67, 3624-3632. [CrossRef]

368. Fardet, A.; Rock, E. Ultra-processed foods and food system sustainability: What are the links? Sustainability 2020, $12,6280$. [CrossRef]

369. Kadandale, S.; Marten, R.; Smith, R. The palm oil industry and noncommunicable diseases. Bull. World Health Organ. 2019, 97, 118-128. [CrossRef] [PubMed]

370. Gesteiro, E.; Guijarro, L.; Sánchez-Muniz, F.J.; Del Carmen Vidal-Carou, M.; Troncoso, A.; Venanci, L.; Jimeno, V.; Quilez, J.; Anadón, A.; González-Gross, M. Palm oil on the edge. Nutrients 2019, 11, 8. [CrossRef] [PubMed]

371. Ghezzal, S.; Postal, B.G.; Quevrain, E.; Brot, L.; Seksik, P.; Leturque, A.; Thenet, S.; Carrière, V. Palmitic acid damages gut epithelium integrity and initiates inflammatory cytokine production. Biochim. Biophys. Acta Mol. Cell Biol. Lipids 2020, 1865. [CrossRef] [PubMed]

372. Martínez, N.; Prieto, I.; Hidalgo, M.; Segarra, A.B.; Martínez-Rodríguez, A.M.; Cobo, A.; Ramírez, M.; Gálvez, A.; MartínezCañamero, M. Refined versus extra virgin olive oil high-fat diet impact on intestinal microbiota of mice and its relation to different physiological variables. Microorganisms 2019, 7, 61. [CrossRef] [PubMed]

373. Rodríguez-García, C.; Sánchez-Quesada, C.; Algarra, I.; Gaforio, J.J. The high-fat diet based on extra-virgin olive oil causes dysbiosis linked to colorectal cancer prevention. Nutrients 2020, 12, 1705. [CrossRef]

374. Patterson, E.; Wall, R.; Fitzgerald, G.F.; Ross, R.P.; Stanton, C. Health implications of high dietary omega-6 polyunsaturated fatty acids. J. Nutr. Metab. 2012, 2012, 539426. [CrossRef]

375. Kaliannan, K.; Wang, B.; Li, X.Y.; Kim, K.J.; Kang, J.X. A host-microbiome interaction mediates the opposing effects of omega-6 and omega-3 fatty acids on metabolic endotoxemia. Sci. Rep. 2015, 5. [CrossRef]

376. Ghosh, S.; DeCoffe, D.; Brown, K.; Rajendiran, E.; Estaki, M.; Dai, C.; Yip, A.; Gibson, D.L. Fish Oil Attenuates Omega-6 Polyunsaturated Fatty Acid-Induced Dysbiosis and Infectious Colitis but Impairs LPS Dephosphorylation Activity Causing Sepsis. PLoS ONE 2013, 8, e55468. [CrossRef]

377. Yang, J.; Yu, J. The association of diet, gut microbiota and colorectal cancer: What we eat may imply what we get. Protein Cell 2018, 9, 474-487. [CrossRef] [PubMed]

378. Chhibber-Goel, J.; Gaur, A.; Singhal, V.; Parakh, N.; Bhargava, B.; Sharma, A. The complex metabolism of trimethylamine in humans: Endogenous and exogenous sources. Expert Rev. Mol. Med. 2016, 18. [CrossRef] [PubMed]

379. Fu, B.C.; Hullar, M.A.J.; Randolph, T.W.; Franke, A.A.; Monroe, K.R.; Cheng, I.; Wilkens, L.R.; Shepherd, J.A.; Madeleine, M.M.; Le Marchand, L.; et al. Associations of plasma trimethylamine $\mathrm{N}$-oxide, choline, carnitine, and betaine with inflammatory and cardiometabolic risk biomarkers and the fecal microbiome in the Multiethnic Cohort Adiposity Phenotype Study. Am. J. Clin. Nutr. 2020, 111, 1226-1234. [CrossRef]

380. Papandreou, C.; Moré, M.; Bellamine, A. Trimethylamine n-oxide in relation to cardiometabolic health-Cause or effect? Nutrients 2020, 12, 1330. [CrossRef]

381. Cho, E.; Zeisel, S.H.; Jacques, P.; Selhub, J.; Dougherty, L.; Colditz, G.A.; Willett, W.C. Dietary choline and betaine assessed by food-frequency questionnaire in relation to plasma total homocysteine concentration in the Framingham Offspring Study. Am. J. Clin. Nutr. 2006, 83, 905-911. [CrossRef]

382. Janeiro, M.H.; Ramírez, M.J.; Milagro, F.I.; Martínez, J.A.; Solas, M. Implication of trimethylamine n-oxide (TMAO) in disease: Potential biomarker or new therapeutic target. Nutrients 2018, 10, 1398. [CrossRef] [PubMed]

383. Alisson-Silva, F.; Kawanishi, K.; Varki, A. Human risk of diseases associated with red meat intake: Analysis of current theories and proposed role for metabolic incorporation of a non-human sialic acid. Mol. Aspects Med. 2016, 51, 16-30. [CrossRef] [PubMed]

384. Abu-Ghazaleh, N.; Chua, W.J.; Gopalan, V. Intestinal microbiota and its association with colon cancer and red/processed meat consumption. J. Gastroenterol. Hepatol. 2020. [CrossRef] 
385. Zaramela, L.S.; Martino, C.; Alisson-Silva, F.; Rees, S.D.; Diaz, S.L.; Chuzel, L.; Ganatra, M.B.; Taron, C.H.; Secrest, P.; Zuñiga, C.; et al. Gut bacteria responding to dietary change encode sialidases that exhibit preference for red meat-associated carbohydrates. Nat. Microbiol. 2019, 4, 2082-2089. [CrossRef] [PubMed]

386. Prescott, S.L.; Logan, A.C. Each meal matters in the exposome: Biological and community considerations in fast-foodsocioeconomic associations. Econ. Hum. Biol. 2017, 27, 328-335. [CrossRef] [PubMed]

387. Zhu, C.; Sawrey-Kubicek, L.; Beals, E.; Rhodes, C.H.; Houts, H.E.; Sacchi, R.; Zivkovic, A.M. Human gut microbiome composition and tryptophan metabolites were changed differently by fast food and Mediterranean diet in 4 days: A pilot study. Nutr. Res. 2020, 77, 62-72. [CrossRef] [PubMed]

388. Gupta, B.; Liu, Y.; Chopyk, D.M.; Rai, R.P.; Desai, C.; Kumar, P.; Farris, A.B.; Nusrat, A.; Parkos, C.A.; Anania, F.A.; et al. Western diet-induced increase in colonic bile acids compromises epithelial barrier in nonalcoholic steatohepatitis. FASEB J. 2020, 34, 7089-7102. [CrossRef]

389. Taleb, S. Tryptophan Dietary Impacts Gut Barrier and Metabolic Diseases. Front. Immunol. 2019, 10, 2113. [CrossRef] [PubMed]

390. He, F.J.; Jenner, K.H.; MacGregor, G.A. WASH-World action on salt and health. Kidney Int. 2010, 78, 745-753. [CrossRef]

391. De Deus Mendonça, R.; Souza Lopes, A.C.; Pimenta, A.M.; Gea, A.; Martinez-Gonzalez, M.A.; Bes-Rastrollo, M. Ultra-processed food consumption and the incidence of hypertension in a mediterranean cohort: The seguimiento universidad de navarra project. Am. J. Hypertens. 2017, 30, 358-366. [CrossRef]

392. Wilck, N.; Matus, M.G.; Kearney, S.M.; Olesen, S.W.; Forslund, K.; Bartolomaeus, H.; Haase, S.; Mahler, A.; Balogh, A.; Marko, L.; et al. Salt-responsive gut commensal modulates TH17 axis and disease. Nature 2017, 551, 585-589. [CrossRef] [PubMed]

393. Bier, A.; Braun, T.; Khasbab, R.; Di Segni, A.; Grossman, E.; Haberman, Y.; Leibowitz, A. A high salt diet modulates the gut microbiota and short chain fatty acids production in a salt-sensitive hypertension rat model. Nutrients 2018, 10, 1154. [CrossRef] [PubMed]

394. Miranda, P.M.; De Palma, G.; Serkis, V.; Lu, J.; Louis-Auguste, M.P.; McCarville, J.L.; Verdu, E.F.; Collins, S.M.; Bercik, P. High salt diet exacerbates colitis in mice by decreasing Lactobacillus levels and butyrate production. Microbiome 2018, 6, 57. [CrossRef] [PubMed]

395. Rinninella, E.; Cintoni, M.; Raoul, P.; Lopetuso, L.R.; Scaldaferri, F.; Pulcini, G.; Miggiano, G.A.D.; Gasbarrini, A.; Mele, M.C. Food components and dietary habits: Keys for a healthy gut microbiota composition. Nutrients 2019, 11, 2393. [CrossRef]

396. Laudisi, F.; Stolfi, C.; Monteleone, G. Impact of food additives on gut homeostasis. Nutrients 2019, 11, 2334. [CrossRef]

397. Schiffman, S.S.; Nagle, H.T. Revisited: Assessing the in vivo data on low/no-calorie sweeteners and the gut microbiota. Food Chem. Toxicol. 2019, 132, 110692. [CrossRef]

398. Suez, J.; Korem, T.; Zeevi, D.; Zilberman-Schapira, G.; Thaiss, C.A.; Maza, O.; Israeli, D.; Zmora, N.; Gilad, S.; Weinberger, A.; et al. Artificial sweeteners induce glucose intolerance by altering the gut microbiota. Nature 2014, 514, 181-186. [CrossRef]

399. Frankenfeld, C.L.; Sikaroodi, M.; Lamb, E.; Shoemaker, S.; Gillevet, P.M. High-intensity sweetener consumption and gut microbiome content and predicted gene function in a cross-sectional study of adults in the United States. Ann. Epidemiol. 2015, 25, 736-742. [CrossRef] [PubMed]

400. Bian, X.; Chi, L.; Gao, B.; Tu, P.; Ru, H.; Lu, K. The artificial sweetener acesulfame potassium affects the gut microbiome and body weight gain in CD-1 mice. PLoS ONE 2017, 12, e0178426. [CrossRef]

401. Gültekin, F. Food Additives and Microbiota. North. Clin. Istanbul 2019, 7, 192. [CrossRef]

402. Turroni, F.; Milani, C.; Duranti, S.; Lugli, G.A.; Bernasconi, S.; Margolles, A.; Di Pierro, F.; Van Sinderen, D.; Ventura, M. The infant gut microbiome as a microbial organ influencing host well-being. Ital. J. Pediatr. 2020, 46, 1-3. [CrossRef]

403. Gollucke, A.; Peres, R.O., Jr.; Ribeiro, D. Polyphenols: A Nutraceutical Approach against Diseases. Recent Pat. Food. Nutr. Agric. 2014, 5, 214-219. [CrossRef]

404. Fowler, A.A.; Truwit, J.D.; Hite, R.D.; Morris, P.E.; Dewilde, C.; Priday, A.; Fisher, B.; Thacker, L.R.; Natarajan, R.; Brophy, D.F.; et al. Effect of Vitamin C Infusion on Organ Failure and Biomarkers of Inflammation and Vascular Injury in Patients with Sepsis and Severe Acute Respiratory Failure: The CITRIS-ALI Randomized Clinical Trial. JAMA. 2019, 322, 1261-1270. [CrossRef]

405. Magrì, A.; Germano, G.; Lorenzato, A.; Lamba, S.; Chilà, R.; Montone, M.; Amodio, V.; Ceruti, T.; Sassi, F.; Arena, S.; et al. High-dose Vitamin C enhances cancer immunotherapy. Sci. Transl. Med. 2020, 12. [CrossRef]

406. Geng, C.; Shaikh, A.S.; Han, W.; Chen, D.; Guo, Y.; Jiang, P. Vitamin D and depression: Mechanisms, determination and application. Asia Pac. J. Clin. Nutr. 2019, 28, 689-694. [CrossRef]

407. Calder, P.C. Feeding the immune system. Proc. Nutr. Soc. 2013, 72, 299-309. [CrossRef]

408. Yang, I.; Corwin, E.J.; Brennan, P.A.; Jordan, S.; Murphy, J.R.; Dunlop, A. The infant microbiome: Implications for infant health and neurocognitive development. Nurs. Res. 2016, 65, 76-88. [CrossRef]

409. Ferrante, G.; Carta, M.; Montante, C.; Notarbartolo, V.; Corsello, G.; Giuffrè, M. Current Insights on Early Life Nutrition and Prevention of Allergy. Front. Pediatr. 2020, 8, 448. [CrossRef]

410. Wiciński, M.; Sawicka, E.; Gębalski, J.; Kubiak, K.; Malinowski, B. Human milk oligosaccharides: Health benefits, potential applications in infant formulas, and pharmacology. Nutrients 2020, 12, 266. [CrossRef]

411. Castanys-Muñoz, E.; Martin, M.J.; Vazquez, E. Building a beneficial microbiome from birth. Adv. Nutr. 2016, 7, 323-330. [CrossRef]

412. Plaza-Díaz, J.; Fontana, L.; Gil, A. Human milk oligosaccharides and immune system development. Nutrients 2018, 10, 1038. [CrossRef] 
413. Van Esch, B.C.; Porbahaie, M.; Abbring, S.; Garssen, J.; Potaczek, D.P.; Savelkoul, H.F.J.; van Neerven, R.J. The Impact of Milk and Its Components on Epigenetic Programming of Immune Function in Early Life and Beyond: Implications for Allergy and Asthma. Front. Immunol. 2020, 11. [CrossRef]

414. Vickers, M.H. Early life nutrition, epigenetics and programming of later life disease. Nutrients 2014, 6, 2165-2178. [CrossRef]

415. Oddy, W.H. Breastfeeding, Childhood Asthma, and Allergic Disease. Ann. Nutr. Metab. 2017, 70, 26-36. [CrossRef]

416. Milani, C.; Duranti, S.; Bottacini, F.; Casey, E.; Turroni, F.; Mahony, J.; Belzer, C.; Delgado Palacio, S.; Arboleya Montes, S.; Mancabelli, L.; et al. The First Microbial Colonizers of the Human Gut: Composition, Activities, and Health Implications of the Infant Gut Microbiota. Microbiol. Mol. Biol. Rev. 2017, 81. [CrossRef] [PubMed]

417. Aw, D.; Silva, A.B.; Palmer, D.B. Immunosenescence: Emerging challenges for an ageing population. Immunology 2007, $120,435-446$. [CrossRef] [PubMed]

418. Maijó, M.; Clements, S.J.; Ivory, K.; Nicoletti, C.; Carding, S.R. Nutrition, diet and immunosenescence. Mech. Ageing Dev. 2014, 136-137, 116-128. [CrossRef]

419. García-Peña, C.; Álvarez-Cisneros, T.; Quiroz-Baez, R.; Friedland, R.P. Microbiota and Aging. A Review and Commentary. Arch Med. Res. 2017, 48, 681-689. [CrossRef]

420. Estrada, J.A.; Contreras, I. Nutritional modulation of immune and central nervous system homeostasis: The role of diet in development of neuroinflammation and neurological disease. Nutrients 2019, 11, 1076. [CrossRef]

421. Maynard, C.; Weinkove, D. The gut microbiota and ageing. Subcell Biochem. 2018, 90, 351-371. [CrossRef] [PubMed] 